\title{
Revision of the aperturally dentate Charopidae (Gastropoda: Stylommatophora) of southern Africa - genus Afrodonta s. lat., with description of five new genera, twelve new species and one new subspecies
}

\author{
David G. HERBERT \\ Department of Natural Sciences, National Museum Wales, Cathays Park, Cardiff, CF10 3NP, UK. \\ Formerly at KwaZulu-Natal Museum, P. Bag 9070, Pietermaritzburg 3201, South Africa. \\ E-mail: phasianella@gmail.com
}

urn:1sid:zoobank.org:author:0C09EE45-6198-482E-857A-EF690C2A016F

\begin{abstract}
The genus Afrodonta s. lat. is shown to comprise several lineages with distinctive shell characters primarily associated with the microsculpture of the protoconch and teleoconch, and the manner in which the apertural barriers are deposited. These lineages comprise Afrodonta s. str. and five new genera: Amatholedonta gen. nov., Biomphalodonta gen. nov., Costulodonta gen. nov., Iterodonta gen. nov. and Phialodonta gen. nov. Twelve new species are described, doubling the diversity of aperturally dentate charopid snails known from southern Africa. All new species are narrow-range endemics. A new subspecies of one of the more widely distributed species of Afrodonta s. str. is also described. Keys to genera and species are provided. New species and subspecies: Afrodonta geminodonta sp. nov., Af. inhluzaniensis leptolamellaris subsp. nov., Af. mystica sp. nov., Af. pentodon sp. nov., Amatholedonta fordycei gen. et sp. nov., Biomphalodonta forticostata gen. et sp. nov., Costulodonta bidens gen. et sp. nov., C. pluridens gen. et sp. nov., Iterodonta ammonita gen. et sp. nov., Phialodonta agulhasae gen. et sp. nov., $P$. atromontana gen. et sp. nov., $P$. aviana gen. et sp. nov. and $P$. rivalalea gen. et sp. nov. New synonyms: Afrodonta bilamellaris londonensis Solem, $1970=$ Afrodonta bilamellaris Melvill \& Ponsonby, 1908. New combinations: Afrodonta acinaces Connolly, 1933, Afrodonta burnupi Connolly, 1933 and Afrodonta trilamellaris Melvill \& Ponsonby, 1908 are transferred to Costulodonta gen. nov.; Afrodonta bimunita Connolly, 1939 is transferred to Amatholedonta gen. nov.; Afrodonta introtuberculata Connolly, 1933 and Afrodonta perfida Burnup, 1912 are transferred to Phialodonta gen. nov.
\end{abstract}

Keywords. Afrodonta s. lat., keys to genera and species, shell microsculpture, narrow-range endemism.

Herbert D.G. 2020. Revision of the aperturally dentate Charopidae (Gastropoda: Stylommatophora) of southern Africa - genus Afrodonta s. lat., with description of five new genera, twelve new species and one new subspecies. European Journal of Taxonomy 629: 1-55 https://doi.org/10.5852/ejt.2020.629 


\section{Introduction}

The phylogenetic relationships of Afrodonta Melvill \& Ponsonby, 1908, treated for the moment sensu lato, are not well resolved. Solem (1970), following Connolly (1939), referred the genus to the Endodontidae, but at that time his concept of this family included the 'charopids' as a subfamily. Later (Solem 1976, 1983), he divided the 'endodontoid' snails of the Pacific Islands into three separate families, Charopidae, Endodontidae and Punctidae. The Endodontidae, he believed, were restricted to islands in the central and south-western Pacific and he regarded the southern African 'endodontoids' (Trachycystis s. lat. and Afrodonta s. lat.) as belonging to the Charopidae: Charopinae (Solem 1983). Subsequently, Schileyko (2001) grouped both Afrodonta s. lat. and Trachycystis s. lat. in the Endodontidae rather than the Charopidae, but referred them to different subfamilies (respectively the Endodontinae and Trachycystinae), on account of the lack of apertural barriers in Trachycystis s. lat. The most recent classification (Bouchet et al. 2017), which incorporated data from molecular studies, referred the Trachycystinae once again to the Charopidae, but the position of Afrodonta remains uncertain. It is currently maintained within the Endodontidae (MolluscaBase 2018), but it is very much a geographical outlier within this family, the other constituent genera all occurring on islands in the central and southwestern Pacific, largely following Solem (1983). In reality, it seems unlikely that Afrodonta s. lat. is genuinely related to these endodontid genera and Solem (1970), based on the anatomy of the pallial cavity described by Connolly (1925), was firmly of the opinion that whatever the true relationships of Afrodonta may be, "it is not a member of the Endodontinae" [Endodontidae] (see Remarks under genus Afrodonta s. str. below). In light of the above, and pending molecular evidence to suggest otherwise, I have opted to follow Solem $(1976,1983)$ and Bruggen $(1980,1988,2007)$ in considering both Trachycystis s. lat. and Afrodonta s. lat. to be referable to the Charopidae (see also Muratov, Abdou \& Bouchet 2005).

To date, Afrodonta has been used as a taxon of convenience to house all minute, aperturally dentate charopid snails occurring in southern and East Africa. Revisions of the genus were undertaken by Burnup (1912), Connolly (1939) and Solem (1970), each author augmenting the data available and describing additional species. In the most recent of these revisions, Solem (1970) discussed a total of 12 species and one subspecies from southern Africa, and also referred the East African Endodonta kempi Connolly, 1925 to Afrodonta. His use of Afrodonta, however, was very much sensu lato, and he noted that it was likely to prove to be a polyphyletic assemblage, rather than a monophyletic entity.

The material studied by Solem included historical material obtained in the early 1900s by collectors such as H.C. Burnup, J. Farquhar, W.E. Jones, A.J. Taynton and H.P. Thomasset, as well as material collected in the early 1960 s by A.C. van Bruggen. In the more than 50 years since then an active field work programme, including the collection and sorting of leaf-litter samples, has resulted in a five-fold increase in the amount of Afrodonta s. lat. material available. Study of this has resulted in the discovery of undescribed species and the identification of diagnostic characters that serve to delimit what appear to be natural groups within Afrodonta s. lat. The purpose of this contribution is to document these newly discovered species- and genus-level taxa, thus drawing attention to previously unrecognised diversity and narrow-range endemism in this group of minute, epiedaphic, forest-dwelling snails. The result is a doubling of the species-level diversity of aperturally dentate charopid snails known from southern Africa.

\section{Material and methods}

The material studied was derived primarily from the collection of the KwaZulu-Natal Museum. This was accumulated over many years, but has been significantly augmented in the last two decades through a programme of field work targeting poorly-surveyed regions of South Africa. Most specimens were collected by the sieving and sorting of dried leaf-litter samples. A key to genera is provided as well as 
keys to species within each genus. Diagnoses are given for all species, including previously described ones. Locality data for all material examined are given for all new species as well as for previously described, narrow-range endemic species. In the case of widely distributed species for which abundant material is available, I give only details of type material and a summary of the distribution. Terms used to describe vegetation types are taken from Mucina \& Rutherford (2006). Eastern Cape (hereafter E. Cape), Northern Cape (hereafter N. Cape), Western Cape (hereafter W. Cape), Free State, KwaZuluNatal, Limpopo and Mpumalanga refer to provinces in South Africa.

Photographs of shells were taken with a Zeiss Axio Zoom V16 dissecting microscope with AxioCam 506 digital camera. Stacked images were then combined using Helicon Focus Pro (Helicon Soft Ltd) to provide extended depth of field. For SEM study, shells were soaked and rinsed to remove as much particulate material as possible, dried, mounted on stubs, coated with gold-palladium, and examined at low accelerating voltage $(5 \mathrm{kV})$ in a Zeiss EVO 10LS scanning electron microscope.

\section{Institutional abbreviations:}

ELM = East London Museum, East London

FMNH $=$ Field Museum of Natural History, Chicago

NHMUK $=$ Natural History Museum, London

NMSA $=$ KwaZulu-Natal Museum, Pietermaritzburg

SAMC $=$ South African Museum, Cape Town

\section{Results}

Class Gastropoda Cuvier, 1795

Subclass Heterobranchia Burmeister, 1837

Order Stylommatophora A. Schmidt, 1855

Superfamily Punctoidea Morse, 1864

Family Charopidae Hutton, 1884

\section{Key to genera of aperturally dentate Charopidae in southern Africa}

1. Protoconch with fine, but well-defined, crisp, axial riblets

- Protoconch smooth or micro-shagreened; lacking crisp, axial riblets (at most with low, indistinct, radial undulations).

2. Protoconch with only axial riblets, spiral sculpture lacking; eastern South Africa .......................... 3

- Protoconch with both spiral threads and axial riblets; W. Cape Iterodonta gen. nov.

3. Spire deeply sunken, teleoconch sculpture of widely-spaced axial riblets with numerous intermediary axial threads Biomphalodonta gen. nov.

- Spire flat or slightly raised, teleoconch sculpture of close-set axial riblets with fewer intermediary axial threads Costulodonta gen. nov.

4. Spire deeply sunken, shell markedly biconcave; Amathole Region of E. Cape.

Amatholedonta gen. nov.

- Spire elevated, flat or at most shallowly sunken

5. Teleoconch sculpture of fine but distinct compound axial riblets with multiple intermediary axial threads; umbilicus wide to very wide

..Phialodonta gen. nov.

- Teleoconch silky, sculptured by simple axial riblets usually of alternating strength; umbilicus narrow to moderate

Afrodonta s. str. 
Genus Afrodonta Melvill \& Ponsonby, 1908

urn:1sid:zoobank.org:act:4D5FE370-F963-46B2-9D66-0D999661727C

Afrodonta Melvill \& Ponsonby, 1908: 133.

\section{Type species}

Afrodonta bilamellaris Melvill \& Ponsonby, 1908, by subsequent designation (Burnup 1912: 335).

\section{Diagnosis}

Shell very small (max. diameter $\pm 1.8 \mathrm{~mm}$ ), discoidal to lenticular or almost subglobose; spire slightly to moderately raised; umbilical width narrow to moderate; whorl depth variable and whorls not conspicuously tightly coiled; periphery rounded to somewhat flat-sided, close to mid-whorl; last adult whorl sometimes descendant prior to aperture. Protoconch smooth or microscopically shagreened, with neither axial nor spiral sculpture, but sometimes with a slight subterminal swelling, comprising $0.67-$ 0.75 whorls beyond apical cap; teleoconch surface texture silky with a sculpture of simple, close-set, microscopic axial riblets of alternating strength, often with even finer spiral threads in their intervals. Aperture lunate; apertural dentition very variable.

\section{Remarks}

Afrodonta comprises a relatively distinct group characterised by the almost smooth protoconch sculpture and silky teleoconch surface consisting of simple riblets of alternating strength. However, shell profile and apertural dentition exhibit considerable variation.

Some basic observations on the external anatomy and radula of the type species and of Af. novemlamellaris were provided by Godwin-Austen (in Melvill \& Ponsonby 1908) and Connolly (1925, 1939), respectively. A peripodial groove is present, but a caudal gland is not evident. The radula formula is (6-7)+ $(8-9)+1+(8-9)+(6-7)$, with tricuspid central and lateral teeth, and somewhat pectinate marginals. The jaw is composed of narrow plates set side-by-side (stegognathous). In 1925, Connolly also described and illustrated the pallial anatomy of Af. novemlamellaris, noting that the ureter was reflected and included a secondary component running parallel to the rectum. Solem (1970) later commented that the presence of a secondary ureter and the configuration of the heart and kidney set Afrodonta apart from Pacific Island endodontids, which lack a secondary ureter.

\section{Key to species of $A$ frodonta}

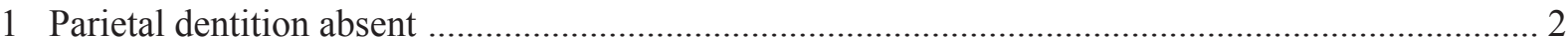

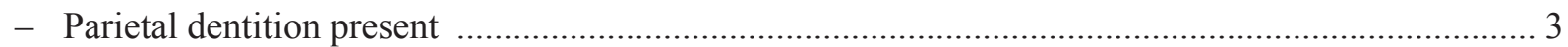

2 Palatal region with a thin, upwardly angled, trigonal lamella; baso-columellar region with two denticles, one much smaller than the other Af. inhluzaniensis leptolamellaris subsp. nov.

- Palatal region with a stout lamella; baso-columellar region with a single well-developed denticle Af. inhluzaniensis inhluzaniensis (Burnup, 1912)

3 Parietal region with a single denticle/lamella

- Parietal region with two denticles/lamellae

4 Aperture lacking further dentition Af. unilamellaris Connolly, 1933

- Palatal and/or baso-columellar dentition present 
5 Palatal region lacking dentition or if present then parietal lamella strong and posteriorly bifid Af. bilamellaris Melvill \& Ponsonby, 1908

- Palatal region with additional dentition, parietal lamella simple Af. mystica sp. nov.

6 Aperture lacking further dentition or with only a weak baso-columellar denticle

Af. connollyi Solem, 1970

- Palatal dentition present 7

7 Parietal lamellae weak; palatal region with 1-3 axially aligned pairs of rounded denticles; no basocolumellar dentition Af. geminodonta sp. nov.

- Parietal lamellae well developed; baso-columellar region with a well-developed denticle. 8

8 Palatal region with a single rounded, thickened, sub-peripheral nodule, plus a narrow, deep-set, subsutural denticle Af. pentodon sp. nov.

- Palatal region with three or more in-running, ridge-like denticles 9

9 Palatal region with three denticles Af. farquhari (Burnup, 1912)

- Palatal region with 6-7 denticles Af. novemlamellaris (Burnup, 1912)

Afrodonta bilamellaris Melvill \& Ponsonby, 1908

Figs $1 \mathrm{~A}-\mathrm{C}, 2,17 \mathrm{~A}-\mathrm{B}$

Afrodonta bilamellaris Melvill \& Ponsonby, 1908: 134, pl. 7, fig. 6.

Afrodonta bilamellaris londonensis Solem, 1970: 359, fig. 2c-d. Syn. nov.

Afrodonta bilamellaris - Godwin-Austen, in Melvill \& Ponsonby 1908: 135. — Connolly 1939: 251, text-fig. 19 (1). - Herbert \& Kilburn 2004: 249, text-fig.

Endodonta [Endodonta (Afrodonta)] bilamellaris - Burnup 1912: 335, pl. 24, fig. 18.

Endodonta (Afrodonta) bilamellaris - Connolly 1912: 127.

Afrodonta bilamellaris bilamellaris - Solem 1970: 358, fig. 2a-b.

\section{Diagnosis}

Shell small, spire slightly raised, whorls slightly flat-sided; protoconch smooth, at most microscopically shagreened (diameter $\pm 315 \mu \mathrm{m}$ ); teleoconch texture silky; sculpture comprising simple, very fine and close-set axial riblets, tending to alternate in strength; spiral sculpture of faint threads in riblet intervals; parietal region with a single well-developed, in-running lamella (sometimes bifurcating posteriorly); baso-columellar region with a well-developed, in-running ridge-like denticle; palatal region usually lacking dentition (exceptionally with a weak supra-peripheral ridge); umbilicus relatively narrow. Shell pale honey-coloured when fresh; diameter up to $1.7 \mathrm{~mm}$.

\section{Material examined}

Afrodonta bilamellaris bilamellaris Melvill \& Ponsonby 1908

Lectotype (by inference, Connolly 1912: 128)

SOUTH AFRICA • KwaZulu-Natal; NHMUK 1908.12.14.54.

Two localities were cited in the original description, Dargle and Edendale Falls; Connolly (1939) stated that the 'type' was from Dargle, but both the NHM register and labels cite Edendale Falls as the locality for lot 1908.12.14.54. 

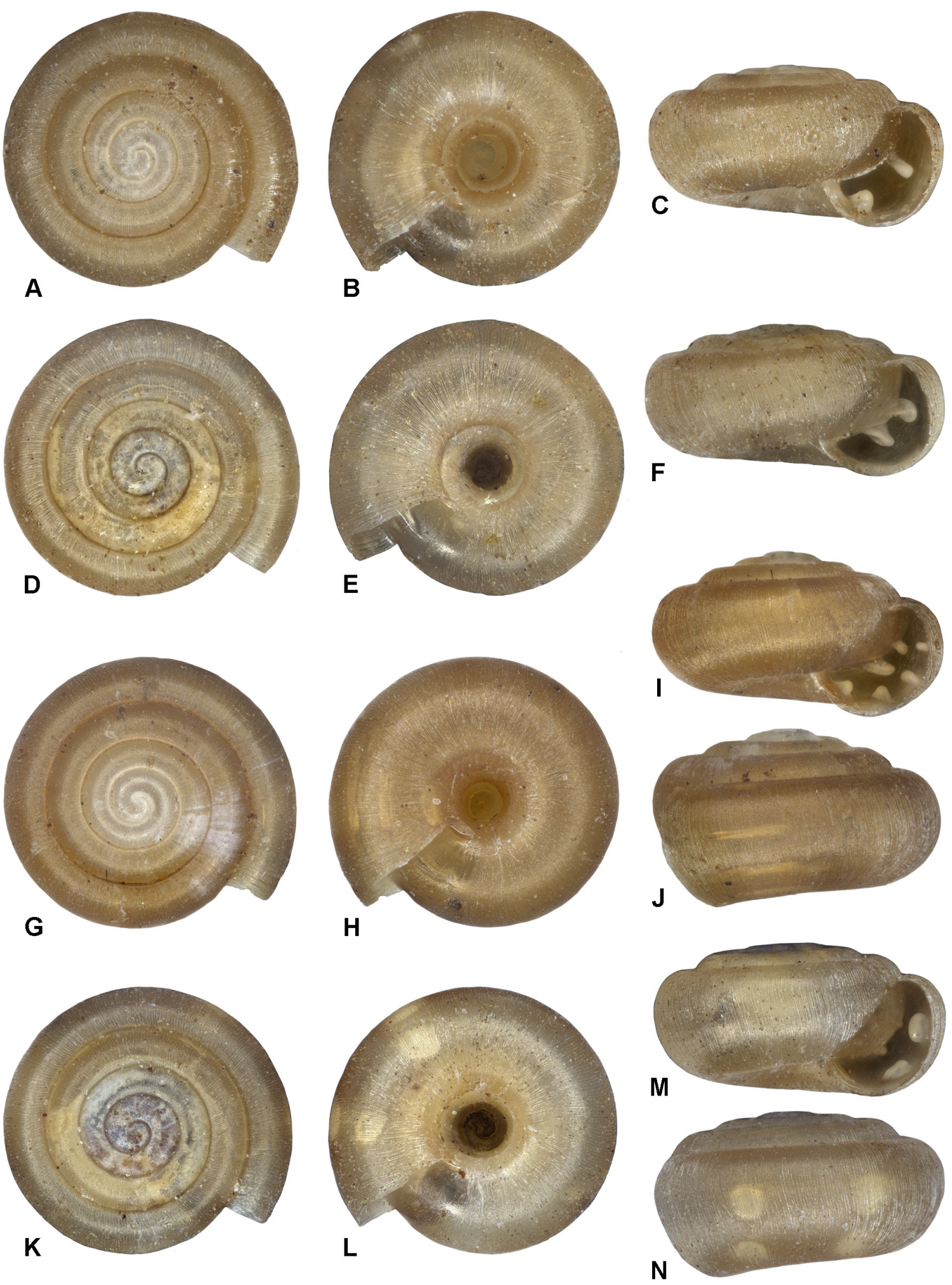

Fig. 1. Shells of Afrodonta species. A-C. Af. bilamellaris Melvill \& Ponsonby, 1908, Karkloof, KwaZuluNatal, diameter 1.45 mm (NMSA W8721). D-F. Af. connollyi Solem, 1970, Middledrift, Thukela Valley, KwaZulu-Natal, diameter 1.52 mm (NMSA V4985). G-J. Af. farquhari (Burnup, 1912), Gamtoos River mouth, E. Cape, diameter $1.39 \mathrm{~mm}$ (NMSA W8688). K-N. Af. geminodonta sp. nov., holotype, diameter 1.36 mm (NMSA V9891/T4241). 


\section{Paralectotypes}

SOUTH AFRICA - KwaZulu-Natal • 1 specimen; same collection data as for lectotype; NHMUK 1908.12.14.55 3 specimens; same collection data as for preceding; NHMUK 1937.12.30.2723 to 2725

- 1 specimen; Dargle; H.C. Burnup leg.; NMSA 2182/T610.

Afrodonta bilamellaris londonensis Solem, 1970

\section{Holotype}

SOUTH AFRICA • E. Cape, East London, Signal Hill; NMSA 4359/T1183.

\section{Paratypes}

SOUTH AFRICA - E. Cape • 2 specimens; same collection data as for holotype; NMSA 4360/T1184; - 2 specimens; same collection data as for preceding; FMNH 159054.

\section{Distribution and conservation}

Endemic to south-eastern South Africa (Fig. 2), ranging widely from central KwaZulu-Natal (Zinkwazi), through E. Cape to eastern W. Cape (Knysna area); in E. Cape and W. Cape it is confined to forests in the coastal hinterland, but in KwaZulu-Natal it ranges inland to the southern mistbelt forests of the Midlands. Inhabits a range of forest and dense thicket-like habitats, from the coast to $1500 \mathrm{~m}$ a.s.l., living in leaf-litter. Not of conservation concern.

\section{Remarks}

Solem (1970) described smaller, strongly dentate specimens from East London as a separate subspecies, Afrodonta bilamellaris londonensis, and similar specimens have been found subsequently at other localities (Port St Johns area, Tsitsikamma and Knysna). However, the reported differences between the

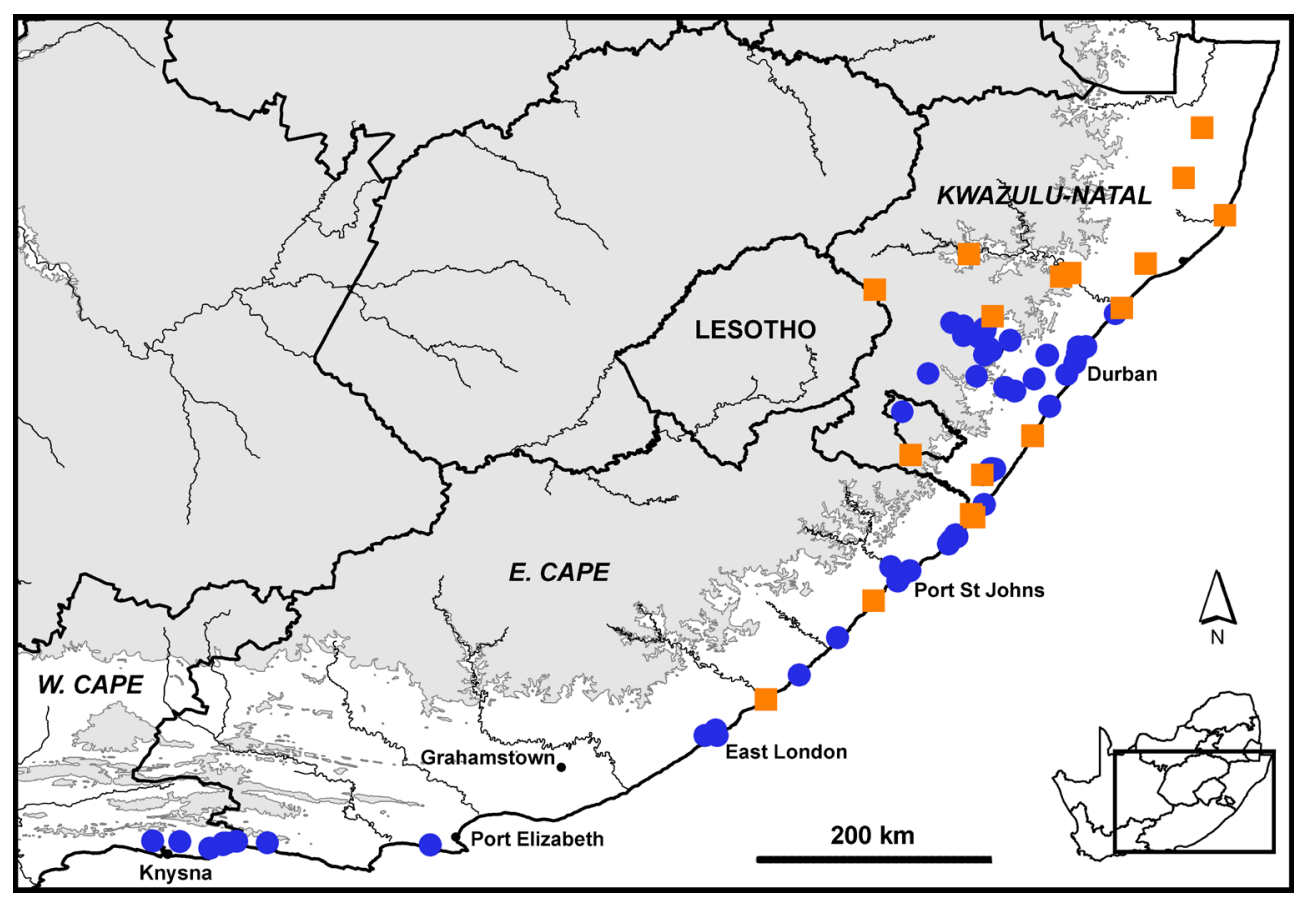

Fig. 2. Distribution of Afrodonta bilamellaris Melvill \& Ponsonby, 1908 (blue circles) and Af. connollyi Solem, 1970 (orange squares). Contour at $1000 \mathrm{~m}$. 
subspecies are a matter of degree and I have not found it possible to discriminate consistently between the two. This, in conjunction with the fact that the records of strongly dentate londonensis specimens are not geographically circumscribed and spatially separated from the nominotypical form, leads me to conclude that the two do not represent distinct entities and that Af. bilamellaris is simply a variable species in terms of the strength of the apertural dentition. This variation occurs to some extent within as well as between populations. In one strongly dentate londonensis population from the Port St Johns area, some individuals evince traces of palatal dentition in the form of a weak supra-peripheral ridge or denticle and occasionally an even weaker sub-peripheral one.

Afrodonta connollyi Solem, 1970

Figs 1D-F, 2, 17C-D

Afrodonta burnupi Connolly, 1933:148 (in part).

Afrodonta connollyi Solem, 1970: 354, fig. 1a-d.

Afrodonta connollyi - Herbert \& Kilburn 2004: 248, text-fig.

\section{Diagnosis}

Shell small, spire slightly raised, whorls somewhat flat-sided; protoconch smooth, at most with faint wavy undulations (diameter $\pm 310 \mu \mathrm{m}$ ); teleoconch texture silky; sculpture comprising simple, very fine and close-set axial riblets, tending to alternate in strength; spiral sculpture of faint threads in riblet intervals; parietal region with two well-developed, in-running lamellae (both extending to or slightly beyond aperture edge); baso-columellar region sometimes with a recessed, rounded, in-running ridge; palatal region lacking dentition; umbilicus relatively narrow. Shell buff to pale ochre when fresh; diameter up to $1.6 \mathrm{~mm}$.

\section{Material examined}

Holotype

SOUTH AFRICA • KwaZulu-Natal, Weenen, Tugela Estate, Hlonyana River bank; 11 Mar. 1928; H.P. Thomasset leg.; NMSA 4357/T1181.

\section{Paratypes}

SOUTH AFRICA - KwaZulu-Natal • 2 specimens; same collection data as for holotype; NMSA 4358/ T1182 - 2 specimens; same collection data as for preceding; these specimens are also paratypes of Afrodonta burnupi Connolly, 1933; NHMUK 1937.12.30.2728 to 2729.

\section{Distribution and conservation}

Endemic to south-eastern South Africa (Fig. 2), ranging from northern KwaZulu-Natal (Mkhuze Game Reserve) south to eastern E. Cape (Kei Mouth), from the coastal hinterland to the Drakensberg foothills; in leaf-litter of various forest types and valley thickets. Not of conservation concern.

\section{Remarks}

Originally confused with Costulodonta burnupi gen. et comb. nov, but in that species the protoconch is axially costate, the umbilicus wider, and the upper parietal lamella is weaker, not extending to the aperture edge.

Afrodonta farquhari (Burnup, 1912)

Figs $1 \mathrm{G}-\mathrm{J}, 3,17 \mathrm{E}-\mathrm{F}$

Endodonta [Endodonta (Afrodonta)] farquhari Burnup, 1912: 339, pl. 24, figs 7-10. 
Endodonta (Afrodonta) farquhari - Connolly 1912: 128.

Afrodonta farquhari - Connolly 1933: text-fig. 1(3); 1939: 253, text fig.19(3). — Solem 1970: 351. — Herbert \& Kilburn 2004: 251, text-fig.

\section{Diagnosis}

Shell very small, spire distinctly raised; protoconch smooth, at most microscopically shagreened (diameter $\pm 360 \mu \mathrm{m}$ ); teleoconch texture silky; sculpture comprising simple, very fine and close-set axial riblets, tending to alternate in strength; spiral sculpture of fine threads in riblet intervals; parietal region with two well-developed, in-running lamellae; baso-columellar region with a recessed in-running ridgelike denticle; palatal region with three in-running lamellae at and below mid-whorl, a fourth smaller and narrower one just below insertion of outer lip; umbilicus relatively narrow. Shell honey-coloured to brown when fresh; diameter up to $1.5 \mathrm{~mm}$.

\section{Material examined}

Holotype

SOUTH AFRICA • E. Cape, Grahamstown; prior to 1912; J. Farquhar leg.; NHMUK 1912.3.25.3.

Burnup (1912) cited Grahamstown as the primary locality for this species and referred to 'the type' in the legend to his illustration of the species. Since he also stated (p. 343) that 'the types of all new species will be placed in the British Museum' and this is the only contemporary NHMUK material from Grahamstown collected by J. Farquhar, I follow Solem (1970) in considering it to be the holotype.

\section{Paratypes}

SOUTH AFRICA - E. Cape • 3 specimens; Port Elizabeth; J. Farquhar leg.; NMSA 2605/T612 • 3 specimens; same collection data as for preceding; NMSA A9217/T2181 • 5 specimens; Port Alfred (Kowie); J. Farquhar leg.; NMSA 2604/T612 • 1 specimen; Bathurst, Trappe's Valley; J. Farquhar leg.; NMSA A9215/T2179 • 4 specimens; same collection data as for preceding; NMSA A9216/T2180.

\section{Distribution and conservation}

Widely distributed in south-eastern South Africa (Fig. 3), ranging from Cape St Francis in E. Cape to the border between of KwaZulu-Natal and Mozambique, almost certainly extending into coastal southern Mozambique, though not as yet recorded there; at altitudes of up to approx. $500 \mathrm{~m}$ a.s.l., rarely recorded far from the coast (furthest inland - Grahamstown and Hluhluwe); living in sandy leaf-litter, primarily in dune forest and coastal bush, but occasionally in lowland and scarp forests. Not of conservation concern.

\section{Remarks}

This species is closest to Af. novemlamellaris, but has fewer palatal lamellae and a weaker basocolumellar denticle. In Af. novemlamellaris the last adult whorl is also proportionately deeper. Afrodonta farquhari largely replaces Af. novemlamellaris in coastal habitats and the species rarely co-occur at precisely the same locality.

Afrodonta geminodonta sp. nov. urn:Isid:zoobank.org:act:B6DE9D83-9082-4DEF-ABD2-0E2B48941827

Figs $1 \mathrm{~K}-\mathrm{N}, 6,17 \mathrm{G}-\mathrm{H}$

\section{Diagnosis}

Shell very small, spire distinctly raised; whorls weakly shouldered; protoconch microscopically shagreened; teleoconch texture silky; sculpture of simple, close-set, microscopic axial riblets; riblets alternating in strength and with even finer spiral threads in their intervals, producing a quadrate micro- 
reticulation; parietal region with two low, in-running ridges, upper one weaker and more deeply recessed; palatal region with 1-3 axially aligned pairs of rounded denticles recessed inside outer lip, outermost pair visible through aperture, others apparent only through translucent shell; lower denticle well below mid-whorl, upper one more or less at mid-whorl just below periphery; umbilicus relatively narrow. Shell corneous-brown to yellowish-brown when fresh; diameter up to $1.4 \mathrm{~mm}$.

\section{Etymology}

From the Latin geminus: twin, and the Greek odontos (odovtos): a tooth; with reference to the paired palatal dentition.

\section{Material examined}

\section{Holotype}

SOUTH AFRICA • E. Cape, Somerset East, Glen Avon Falls; $32.67700^{\circ}$ S, $25.63681^{\circ}$ E; 985 m a.s.1.; 19 Jan. 2002; D.G. Herbert, M. Bursey and G. Redman leg.; in leaf-litter under bush clumps and in forest patch near base of falls; diameter $1.36 \mathrm{~mm}$, height $0.73 \mathrm{~mm}$; NMSA V9891/T4241.

\section{Paratypes}

SOUTH AFRICA - E. Cape • 11 specimens; Kaboega Game Farm; 33.26719 S, $25.42147^{\circ}$ E; $450 \mathrm{~m}$ a.s.1.; 10 Mar. 2008; D.G. Herbert, L.S. Davis and M. Cole leg.; mixed woody vegetation in blind-ending kloof with stream and pools, in leaf-litter; NMSA W6248/T4243 • 16 specimens; same collection data as for holotype; NMSA P1010/T4244 • 2 specimens; Somerset East, Glen Avon Falls; $32.67700^{\circ} \mathrm{S}$, 25.63681 ${ }^{\circ}$ E; 25 Jan. 2011; M. Cole, V. Ndibo and R. Daniels leg.; ELM D17632/T170 • 1 specimen;

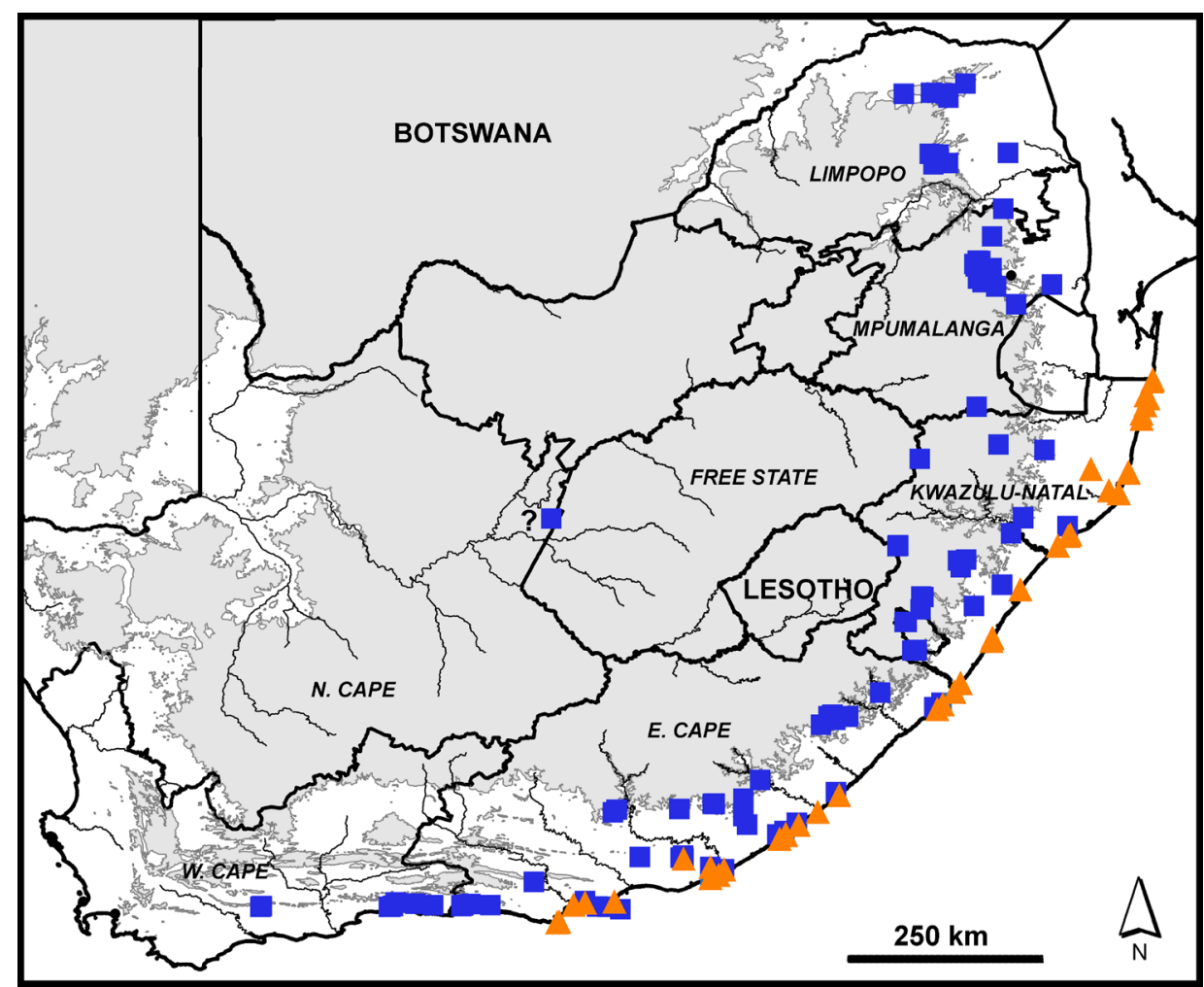

Fig. 3. Distribution of Afrodonta farquhari (Burnup, 1912) (orange triangles) and Af. novemlamellaris (Burnup, 1912) (blue squares). The distribution of Af. novemlamellaris continues north into Malawi. Contour at $1000 \mathrm{~m}$. 
Grahamstown, Fern Kloof; $33.337^{\circ}$ S, $26.537^{\circ}$ E; \pm 500 m a.s.1.; Dec. 1912; J. Farquhar leg.; NMSA V3563/T4242.

\section{Description}

Shell very small, diameter up to $1.4 \mathrm{~mm}, \mathrm{H} / \mathrm{D}$ ratio \pm 0.54 ; spire distinctly raised; suture indented and apical portion of whorls strongly convex, whorls thus weakly shouldered; periphery somewhat above mid-whorl; whorls slightly flattened below periphery. Protoconch comprising apical cap plus approx. 0.75 whorl; diameter $\pm 360 \mu \mathrm{m}$; microscopically shagreened. Teleoconch of up to 3.0 whorls; surface texture silky; sculpture of simple, close-set, microscopic axial riblets; riblets alternating in strength and with even finer spiral threads in their intervals, producing a quadrate micro-reticulation. Umbilicus deep and relatively narrow. Aperture obliquely lunate, somewhat broader basally; parietal region with two low, in-running ridges, lower one ending level with edge of aperture, upper one weaker and more deeply recessed; baso-columellar dentition lacking; palatal region with 1-3 (usually 2) axially aligned pairs of rounded denticles recessed $1 / 8-1 / 3$ whorl behind outer lip, the outermost pair visible through aperture, the others apparent only through translucent shell; lower denticle well below mid-whorl, upper one more or less at mid-whorl just below periphery; number and position of denticle pairs somewhat variable and related to degree of development. Shell corneous-brown to yellowish-brown when fresh.

\section{Distribution and conservation}

A narrow-range endemic (Fig. 6), known only from the interior of the Albany Thicket biome, north of Port Elizabeth, at altitudes of 450-1000 m; in leaf-litter of isolated patches of southern mistbelt forest. Forest patches in the Addo Elephant National Park and in nature reserves around Somerset East and Grahamstown need to be surveyed in the hope of finding extant colonies of this species in formally protected areas.

\section{Remarks}

Afrodonta geminodonta sp. nov. is characterised by its weak parietal lamellae and strong, paired palatal dentition.

\section{Afrodonta inhluzaniensis (Burnup, 1912)}

As noted by Solem (1970), this species exhibits considerable variation in the shape and size of the apertural denticles. He was, however, unable to detect any pattern in this variation or any consistent differences between populations. This notwithstanding, the larger amount material now available has revealed some variation that is broadly congruent with geographical location. The typical form with a single stout, ridge-like baso-columellar denticle and a well-developed palatal lamella with a thickened apical crest is found in the forests of the interior of KwaZulu-Natal, from the Midlands (southern mistbelt forest) to the Drakensberg foothills (northern afrotemperate forest), at altitudes of over $1000 \mathrm{~m}$. By contrast, throughout the coastal strip from Zululand to East London, in coastal and scarp forests up to $500 \mathrm{~m}$ in altitude, specimens exhibit consistent differences in the form and strength of the apertural dentition, by which they can be readily distinguished from the typical form. Since this coastal form is geographically disjunct from the typical one, with a hiatus in distribution records at altitudes between approx. $500 \mathrm{~m}$ to $1000 \mathrm{~m}$, I propose to recognise it as a separate subspecies.

Afrodonta inhluzaniensis inhluzaniensis (Burnup, 1912) Figs $4 \mathrm{~A}-\mathrm{C}, 5,17 \mathrm{I}-\mathrm{J}$

Endodonta [Endodonta (Afrodonta)] inhluzaniensis Burnup, 1912: 342, pl. 24, figs 14-17.

Endodonta (Afrodonta) inhluzaniensis - Connolly 1912: 128. 

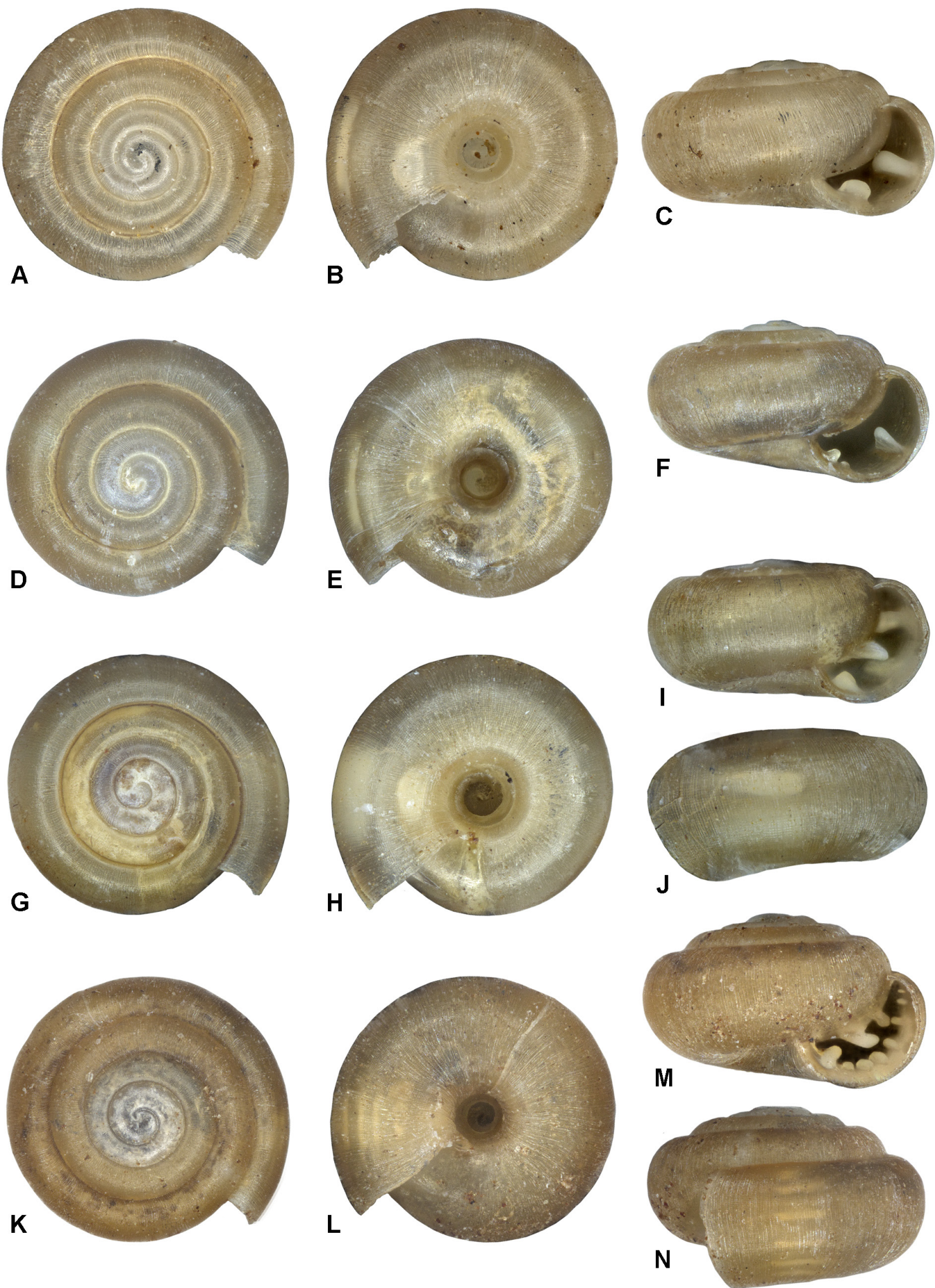

Fig. 4. Shells of Afrodonta species. A-C. Af. inhluzaniensis inhluzaniensis (Burnup, 1912), Balgowan, KwaZulu-Natal, diameter $1.42 \mathrm{~mm}$ (NMSA V7240). D-F. Af. inhluzaniensis leptolamellaris subsp. nov., holotype, diameter $1.2 \mathrm{~mm}$ (NMSA V7615/T4235). G-J. Af. mystica sp. nov., holotype, diameter 1.16 mm (NMSA V4993/4237). K-N. Af. novemlamellaris (Burnup, 1912), Somerset East, E. Cape, diameter $1.32 \mathrm{~mm}$ (NMSA W752). 
Afrodonta inhluzaniensis - Connolly 1939: 251, text-fig. 19(5). — Solem 1970: 362. — Herbert \& Kilburn 2004: 248, text-fig.

\section{Diagnosis}

Shell very small, spire raised; protoconch smooth, at most microscopically shagreened (diameter 320 $350 \mu \mathrm{m}$ ); teleoconch texture silky; sculpture comprising simple, very fine and close-set axial riblets of alternating strength; spiral sculpture of indistinct threads in riblet intervals; parietal region lacking dentition; baso-columellar region typically with a strong, transversely-elongate denticle, its apex rounded or flat; palatal region with a single robust trigonal lamella just below periphery, angled upward and with a thickened crest; shape and strength of denticles somewhat variable; umbilicus relatively narrow. Shell corneous to golden-brown when fresh; diameter up to $1.5 \mathrm{~mm}$.

\section{Material examined}

\section{Holotype}

SOUTH AFRICA • KwaZulu-Natal, Inhluzani Mountain [Dargle area, Nhlosane]; prior to 1912; H.C. Burnup leg.; NHMUK 1912.3.25.2.

\section{Paratypes}

SOUTH AFRICA • 3 specimens; same collection data as for holotype; NMSA 2607/T614.

\section{Distribution and conservation}

Endemic to eastern South Africa (Fig. 5), ranging widely from the Soutpansberg and Wolkberg in Limpopo, along the Mpumalanga escarpment, and throughout much of the KwaZulu-Natal interior, at altitudes in excess of $1000 \mathrm{~m}$; in leaf-litter of mistbelt and northern afrotemperate forest. Not of conservation concern.

\section{Remarks}

Specimens from the northern mistbelt forest in Mpumalanga and Limpopo closely resemble typical specimens from the KwaZulu-Natal interior. They retain a single baso-columellar denticle, but it is less robust than in the typical form and the palatal lamella is slender, strongly trigonal and its crest only slightly thickened. In addition, they rarely attain as large a size as those from KwaZulu-Natal and usually have a proportionately more elevated shell (H/D ratio closer to 0.65 compared with 0.55 ). Since these differences are relative and exhibit some overlap, I do not consider these northern populations worthy of recognition as a separate entity.

Afrodonta inhluzaniensis leptolamellaris subsp. nov. urn:1sid:zoobank.org:act:823F6241-748D-4994-A5D1-56AE413A4553

Figs 4D-F, 5, 17K-L

\section{Diagnosis}

Shell as in Af. inhluzaniensis inhluzaniensis, but baso-columellar denticle present as two smaller, unequally sized denticles, the larger of which is somewhat pointed with the smaller one lying to its right; the latter, though sometimes very small and hard to see through the aperture, is usually evident externally by transparency; palatal lamella prominent, but slender, strongly angled upwards, its crest only slightly thickened.

\section{Etymology}

From the Greek leptos ( $\lambda \varepsilon \pi \tau o ́ s)$ : thin, slender, and the Latin lamina, diminutive of lamella: a small plate or blade; with reference to the narrow palatal lamella. 


\section{Material examined}

\section{Holotype}

SOUTH AFRICA • KwaZulu-Natal, Ongoye Forest; $28.848^{\circ}$ S, $31.717^{\circ}$ E; 350 m a.s.1.; 1 Sep. 1997; M. Lawes and H. Adie leg.; coastal scarp forest, in leaf-litter; diameter $1.2 \mathrm{~mm}$, height $0.69 \mathrm{~mm}$; NMSA V7615/T4235.

\section{Paratypes}

SOUTH AFRICA - KwaZulu-Natal - 4 specimens; same collection data as for holotype; NMSA P1008/T4236 • 9 specimens; Amatikulu Nat. Res.; 29.115 ${ }^{\circ}$ S, $31.598^{\circ}$ E; 45 m a.s.1.; 22 Jan. 2000; D.G. Herbert leg.; coastal forest; NMSA V8084/T4231 • 4 specimens; Shongweni Resource Res.; 29.8550 ${ }^{\circ}$ S, $30.7267^{\circ}$ E; 400 m a.s.l.; 16 Mar. 1998; D.G. Herbert leg.; riverine woodland, in leaf-litter; NMSA V6597/T4233 • 3 specimens; Oribi Gorge Nat. Res., Hoopoe Falls trail; $30.70765^{\circ}$ S, $30.26992^{\circ}$ E; 225 m a.s.l.; 5 Oct. 2001; D.G. Herbert leg.; scarp forest, in leaf-litter; NMSA V9452/T4234. - E. Cape • 33 specimens; Mkambati Nat. Res.; $31.31806^{\circ}$ S, $29.9672^{\circ}$ E; 28 m a.s.1.; 26 Jan. 2008; Earthwatch leg.; station ECMF12; forest, in leaf-litter; NMSA W6446/T4230 • 8 specimens; East London, Umtiza Nat. Res.; $33.016^{\circ} \mathrm{S}, 27.809^{\circ} \mathrm{E} ; 170 \mathrm{~m}$ a.s.1.; 4 Mar. 2000; D.G. Herbert leg.; coastal forest, in leaflitter; NMSA V8039/T4232 - 7 specimens; East London, Umtiza Nat. Res., west side of Buffalo Pass; $33.013472^{\circ} \mathrm{S}, 27.79553^{\circ} \mathrm{E}$; 8 Apr. 2002; M.L. Bursey leg.; coastal forest, in leaf-litter; ELM D15561/ T171.

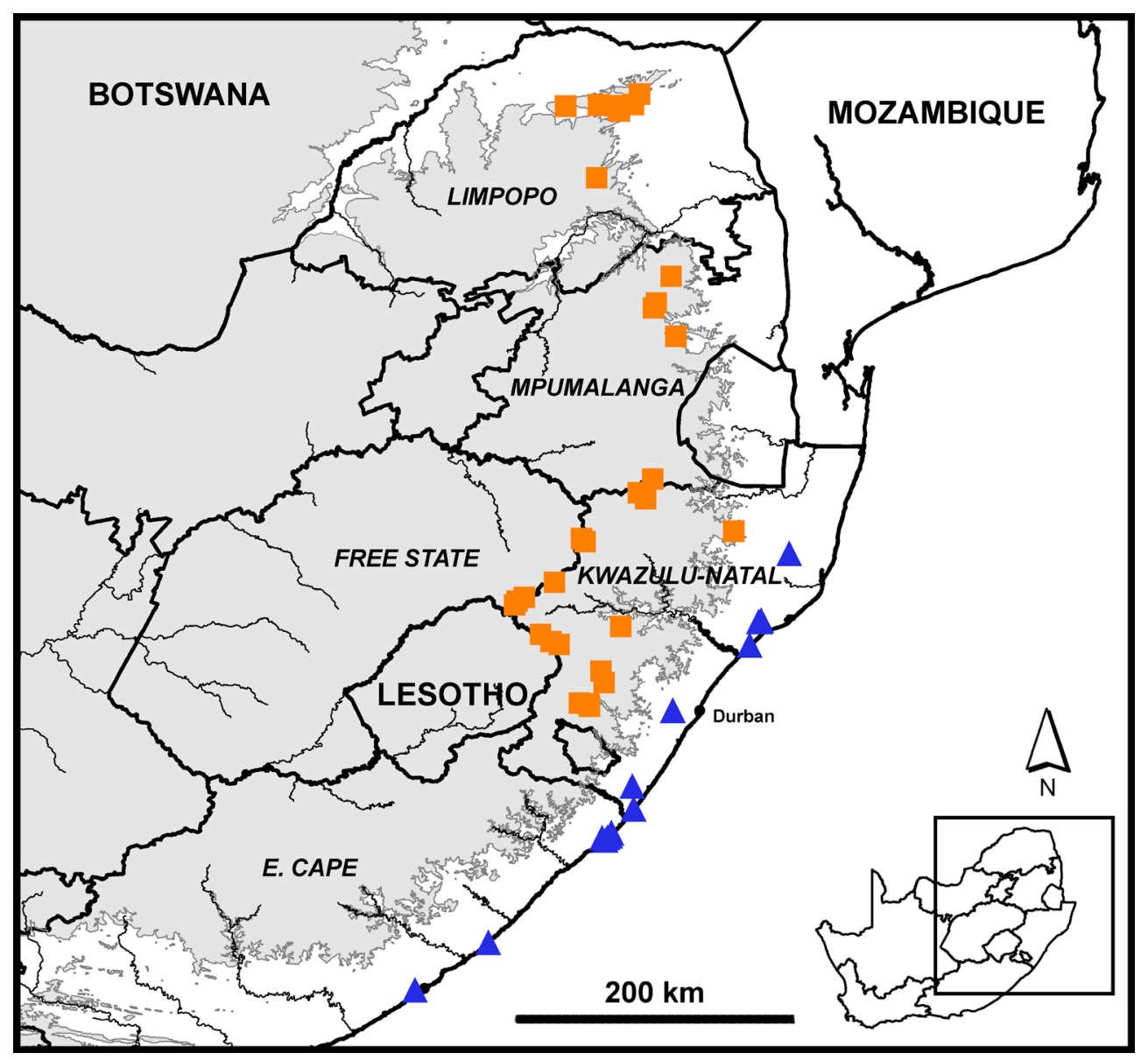

Fig. 5. Distribution of Afrodonta inhluzaniensis inhluzaniensis (Burnup, 1912) (orange squares) and Af. inhluzaniensis leptolamellaris subsp. nov. (blue triangles). Contour at $1000 \mathrm{~m}$. 


\section{Other material}

SOUTH AFRICA - KwaZulu-Natal • 1 specimen; Hluhluwe Game Res.; $28.077^{\circ}$ S, 32.045 E $4460 \mathrm{~m}$ a.s.1.; 29 Nov. 1998; D.G. Herbert, M. Seddon and P. Tattersfield leg.; scarp forest, in leaf-litter; NMSA V7673 • 2 specimens; Ongoye Forest; $28.83110^{\circ} \mathrm{S}, 31.72820^{\circ}$ E; 23 Jun. 2015; D. Herbert and L. Davis leg.; scarp forest, in leaf-litter; NMSA P0388 • 3 specimens; Ongoye Forest; $28.848^{\circ} \mathrm{S}, 31.700^{\circ} \mathrm{E}$; $1 \mathrm{Sep}$. 1997; M. Lawes and H. Adie leg.; coastal scarp forest, regenerating Eucalyptus plantation, in leaf-litter; NMSA V7575 • 11 specimens; Shongweni Resource Res.; $29.855^{\circ}$ S, $30.730^{\circ}$ E; 400 m a.s.l.; 1 Mar. 1997; NMSA Dept of Mollusca leg.; thick valley bushveld and woodland, in leaf-litter; NMSA V4125 - 1 specimen; Mpenjati Nat. Res., Yengele Trail; $30.968^{\circ}$ S, 30.285 E; 19 Dec. 1997; K. Cradock leg.; dune forest; NMSA V6808 1 specimen; Mpenjati Nat. Res., Yengele Trail; $30.96910^{\circ} \mathrm{S}, 30.28197^{\circ} \mathrm{E}$; 28 Dec. 2002; D.G. Herbert leg.; dune forest, in leaf-litter; NMSA W384. - E. Cape 7 specimens; Mtentu River mouth, forest on north side of gorge; $31.2383^{\circ} \mathrm{S}, 30.0351^{\circ} \mathrm{E}$; 20 May 2001; D.G. Herbert leg.; coastal forest, in leaf-litter; NMSA V9146 9 specimens; Mkambati Nat. Res., forest on south side of Mtentu estuary, on top of gorge; 31.2419 ${ }^{\circ}$ S, 30.0299 E; 21 May 2001; D.G. Herbert leg.; coastal forest, in leaf-litter; NMSA V9149 • 1 specimen; Mkambati Nat. Res.; $31.27292^{\circ} \mathrm{S}, 30.02169^{\circ} \mathrm{E} ; 10 \mathrm{~m}$ a.s.1.; 27 Jan. 2008; Earthwatch leg.; station ECMF13, forest, in leaf-litter; NMSA W6461 1 specimen; Mkambati Nat. Res.; 31.29027 ${ }^{\circ}$ S, $29.99026^{\circ}$ E; 50 m a.s.1.; 26 Jan. 2008; Earthwatch leg.; station ECMF11, forest, in leaf-litter; NMSA W6441 - 2 specimens; Mkambati Nat. Res., Gwe Gwe forest walk; $31.2904^{\circ} \mathrm{S}, 29.9897^{\circ} \mathrm{E}$; $90 \mathrm{~m}$ a.s.1.; 5 Mar. 2001; D.G. Herbert leg.; small patch of coastal forest, in leaflitter; NMSA V8975 4 specimens; Mkambati Nat. Res., 'Super Bowl' forest at junction of Msikaba and KwaDlambu Rivers; $31.2955^{\circ}$ S, $29.9292^{\circ}$ E; 5 Mar. 2001; D.G. Herbert leg.; indigenous forest, in leaf-litter; NMSA V8953 • 4 specimens; Mazeppa Bay area; $32.48008^{\circ}$ S, 28.64310 E; 23 Feb. 2006; D.G. Herbert and L.S. Davis leg.; dune forest, in leaf-litter; NMSA W5557.

\section{Distribution and conservation}

Endemic to eastern South Africa (Fig. 5), occurring in the coastal hinterland of KwaZulu-Natal and E. Cape, from Zululand (Hluhluwe) to East London, from sea level to $460 \mathrm{~m}$ a.s.l.; in leaf-litter of coastal and scarp forests. Not of conservation concern.

\section{Remarks}

Afrodonta inhluzaniensis leptolamellaris subsp. nov. is clearly close to the nominotypical subspecies. However, its geographical separation from the latter, together with slight but consistent differences in apertural characters indicate that it merits recognition as an entity distinct therefrom.

Afrodonta mystica sp. nov. urn:lsid:zoobank.org:act:95482B02-41BA-4129-A4B1-32DD8DF1D095

Figs 4G-J, 6, 17M-N

\section{Diagnosis}

Shell very small, spire slightly raised; protoconch microscopically shagreened or malleate; teleoconch surface silky; sculpture of simple, close-set, microscopic axial riblets; aperture with a well-developed, crescentic, in-running parietal lamella and a strong baso-columellar denticle; palatal region with a strong, deeply recessed, ridge-like denticle just above mid-whorl, plus a broad, thickened pad below mid-whorl, opposite and below parietal lamella; umbilicus relatively narrow. Shell corneous-brown to yellowish-brown when fresh; diameter up to $1.2 \mathrm{~mm}$. 


\section{Etymology}

From the Greek mystikos ( - long considered a region of mystery in Zulu folklore and to this day a place of secrecy, subterfuge and skulduggery.

\section{Material examined}

\section{Holotype}

SOUTH AFRICA • KwaZulu-Natal, Nkandla Forest; $28.733^{\circ}$ S, 31.133 E; 900 m a.s.1.; 10 Aug. 1997; D.G. Herbert leg.; mistbelt Podocarpus forest, in leaf-litter; diameter $1.16 \mathrm{~mm}$, height $0.61 \mathrm{~mm}$; NMSA V4993/T4237.

\section{Paratypes}

SOUTH AFRICA • 3 specimens; same collection data as for holotype; NMSA P1009/T4238.

\section{Description}

Shell very small, diameter up to $1.2 \mathrm{~mm}, \mathrm{H} / \mathrm{D}$ ratio \pm 0.53 ; spire slightly raised; suture indented and apical portion of whorls strongly convex, whorls thus weakly shouldered; periphery more or less at mid-whorl, evenly rounded; last adult whorl slightly descendant. Protoconch comprising apical cap plus approx. 0.75 whorl; diameter $\pm 310 \mu \mathrm{m}$; microscopically shagreened or malleate. Teleoconch of up to 2.75 whorls; surface texture silky; sculpture of simple, close-set, microscopic axial riblets; riblets alternating in strength and with even finer spiral threads in their intervals. Umbilicus relatively narrow. Aperture obliquely lunate; parietal region with a well-developed, crescentic, in-running lamella situated well below mid-whorl, extending just beyond edge of aperture, its interior end with a distinct downward deflection; baso-columellar region with a strong denticle (shape somewhat variable); palatal region with a strong, deeply recessed, ridge-like denticle just above mid-whorl, its crest thickened, plus a broad, thickened pad below mid-whorl, opposite and below parietal lamella. Shell corneous-brown to yellowish-brown when fresh.

\section{Distribution and conservation}

A narrow-range endemic (Fig. 6), known only from Nkandla Forest, KwaZulu-Natal, at approx. $900 \mathrm{~m}$ a.s.l.; living in leaf-litter of transitional mistbelt/scarp forest. This forest is formally protected and under the care of the provincial conservation authority, Ezemvelo KwaZulu-Natal Wildlife.

\section{Remarks}

The only other species with a single parietal lamella, Afrodonta bilamellaris and Af. unilamellaris, lack palatal dentition.

Afrodonta novemlamellaris (Burnup, 1912)

Figs 3, 4K-N, 17O-P

Endodonta [Endodonta (Afrodonta)] novemlamellaris Burnup, 1912: 341, pl. 24, figs 11-13.

Endodonta (Afrodonta) novemlamellaris - Connolly 1925: 139, text-fig. 9; 1912: 128.

Arfodonta [sic] novemlamellaris - Connolly 1933: 146, text-fig. 1(4), pl. 7, fig. 1.

Afrodonta novemlamellaris - Connolly 1939: 253, text-figs 19(4), 20. — Solem 1970: 350. — Bruggen \&

Meredith 1984: 162. — Herbert \& Kilburn 2004: 251, text-fig. — Bruggen 2007: 28. 


\section{Diagnosis}

Shell very small, spire distinctly raised, last adult whorl relatively deep, lenticular to almost subglobose; protoconch smooth, at most microscopically shagreened or malleate (diameter $\pm 320 \mu \mathrm{m}$ ); teleoconch texture silky; sculpture comprising simple, very fine and close-set axial riblets of alternating strength; spiral sculpture of fine threads in riblet intervals; parietal region with two well-developed, in-running lamellae; baso-columellar region with a strong, ridge-like denticle; palatal region with 5-8 in-running lamellae, those above periphery weaker; umbilicus relatively narrow. Shell whitish to dark purplishbrown when fresh; diameter up to $1.45 \mathrm{~mm}$.

\section{Material examined}

\section{Holotype}

SOUTH AFRICA • E. Cape, Grahamstown; prior to 1912; J. Farquhar leg.; NHMUK 1912.3.25.4.

\section{Paratypes}

SOUTH AFRICA - E. Cape - 1 specimen; Grahamstown, Mountain Drive; prior to 1912; NMSA A9214/T2178 • 1 specimen; Kowie [Port Alfred]; NHMUK 1937.12.30.2763 • 2 specimens; Bathurst, Trappes Valley; NMSA A9619/T615.

\section{Distribution and conservation}

The widest ranging of all aperturally dentate charopid snails in southern Africa (Fig. 3) Recorded from Grootvadersbosch in W. Cape through much of E. Cape and KwaZulu-Natal, the escarpment of Mpumalanga, and the Soutpansberg and Wolkberg massifs in Limpopo. Ranges beyond South Africa to Mount Vengo (Monte Panga) in the highlands between Zimbabwe and Mozambique (Connolly 1925), and northward to Malawii (Bruggen \& Meredith 1984; Bruggen 2007). An isolated record (Connolly 1939) from Kimberley (N. Cape) requires confirmation. Lives in leaf-litter of a wide variety of forest and woodland habitats, from the coast to $1800 \mathrm{~m}$ a.s.1.. Not of conservation concern.

\section{Remarks}

Closest to Af. farquhari, but that species has fewer palatal lamellae and a weaker baso-columellar denticle, and the last adult whorl is not as deep.

\section{Afrodonta pentodon sp. nov. urn:lsid:zoobank.org:act:ED136FF6-F319-4C79-9EBA-B225283F7F6D}

Figs 6, 7A-D, 17Q-R

\section{Diagnosis}

Shell very small, spire distinctly raised; protoconch microscopically shagreened; teleoconch texture silky; sculpture of simple, close-set, microscopic axial riblets; aperture with two well-developed, inrunning parietal lamellae, lower one extending just beyond edge of aperture, upper one recessed a short distance, and a rounded baso-columellar denticle; palatal region with a low, broad, in-running, thickened pad situated well below mid-whorl, plus a small, narrow, deep-set, subsutural denticle; umbilicus narrow to moderate. Shell corneous-brown when fresh; diameter up to $1.5 \mathrm{~mm}$.

\section{Etymology}

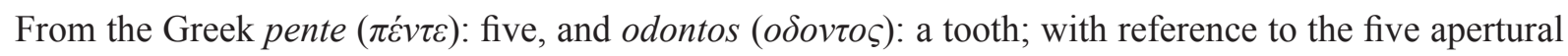
teeth. 


\section{Material examined}

\section{Holotype}

SOUTH AFRICA • KwaZulu-Natal, Ngele Forest; $30.533^{\circ}$ S, $29.633^{\circ}$ E; 1350 m a.s.1.; 3 Mar. 1997; D.G. Herbert leg.; mistbelt Podocarpus forest, sorted from dried leaf-litter sample; diameter $1.45 \mathrm{~mm}$, height $0.84 \mathrm{~mm}$; NMSA V6950/T4239.

\section{Paratypes}

SOUTH AFRICA • 4 specimens; KwaZulu-Natal, Ngele Forest; $30.5309^{\circ}$ S, $29.6846^{\circ}$ E; 1290 m a.s.1.; 3 Mar. 1997; D.G. Herbert leg.; mistbelt Podocarpus forest, in leaf-litter and under logs; NMSA V8275/ $\mathrm{T} 4240$.

\section{Other material}

SOUTH AFRICA - KwaZulu-Natal • 1 specimen; Ngele Forest; $30.53^{\circ} \mathrm{S}, 29.63^{\circ}$ E; $1350 \mathrm{~m}$ a.s.1.; 17 Feb. 1997; D. Barraclough leg.; mistbelt Podocarpus forest, sorted from leaf-litter; NMSA V4864 • 1 specimen; same collection data as for preceding; 27 Mar. 1998; C. Symes leg.; NMSA V6887.

\section{Description}

Shell very small, diameter up to $1.5 \mathrm{~mm}, \mathrm{H} / \mathrm{D}$ ratio \pm 0.58 ; spire distinctly raised; suture indented and apical portion of whorls strongly convex, whorls thus weakly shouldered; periphery more or less at mid-whorl; whorls slightly flat-sided; last adult whorl descendant. Protoconch comprising apical cap plus approx. 0.75 whorl; diameter $\pm 310 \mu \mathrm{m}$; microscopically shagreened. Teleoconch of up to 3.25 whorls; surface texture silky; sculpture of simple, close-set, microscopic axial riblets; riblets alternating

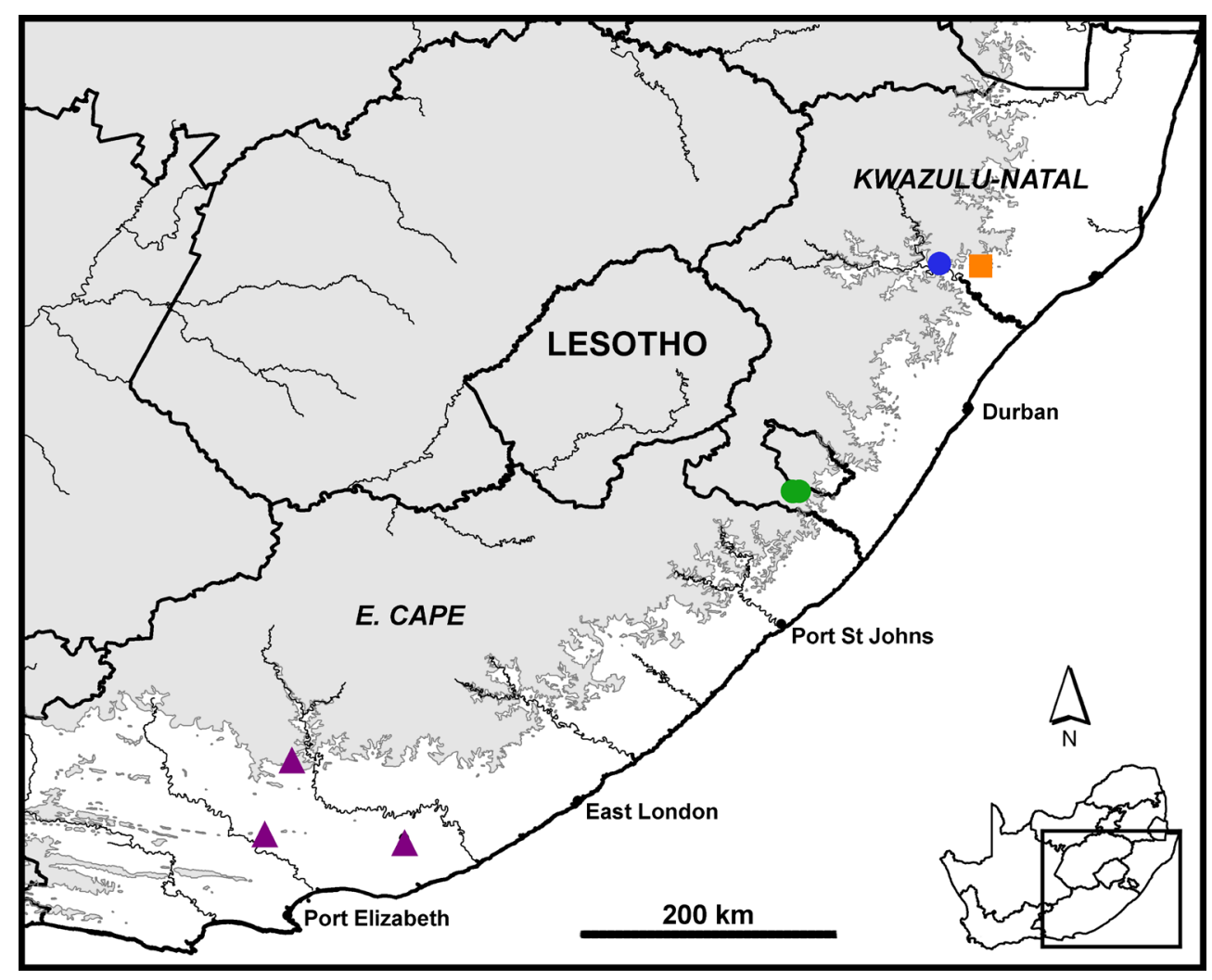

Fig. 6. Distribution of narrow-range Afrodonta species. Af. geminodonta sp. nov. (purple triangles), Af. mystica sp. nov. (orange square), Af. pentodon sp. nov. (green circles) and Af. unilamellaris Connolly, 1933 (blue circle). Contour at $1000 \mathrm{~m}$. 
in strength and with even finer spiral threads in their intervals (sometimes scarcely evident). Umbilicus narrow to moderate. Aperture obliquely lunate, broader basally; parietal region with two well-developed, in-running lamellae, lower one extending just beyond edge of aperture, upper one recessed a short distance and with a flat-topped crest internally; baso-columellar region with a rounded denticle; palatal region with a low, broad, in-running, thickened pad situated well below mid-whorl, plus a small, narrow, deep-set, subsutural denticle. Shell corneous-brown when fresh.

\section{Distribution and conservation}

A narrow-range endemic (Fig. 6), known only from Ngele Forest, near Kokstad, KwaZulu-Natal, at 1290-1350 m a.s.l.; living in leaf-litter of southern mistbelt forest. Although this forest is theoretically protected, access is completely uncontrolled and it is surrounded by exotic timber plantation heavily invaded by alien plants.

\section{Remarks}

A distinctive species with characteristic dentition, including a thickened palatal pad.

Afrodonta unilamellaris Connolly, 1933

Figs 6, 7E-G, 18A-B

Afrodonta unilamellaris Connolly, 1933: 146, text-fig. 1(6), pl. 7, figs 2-4.
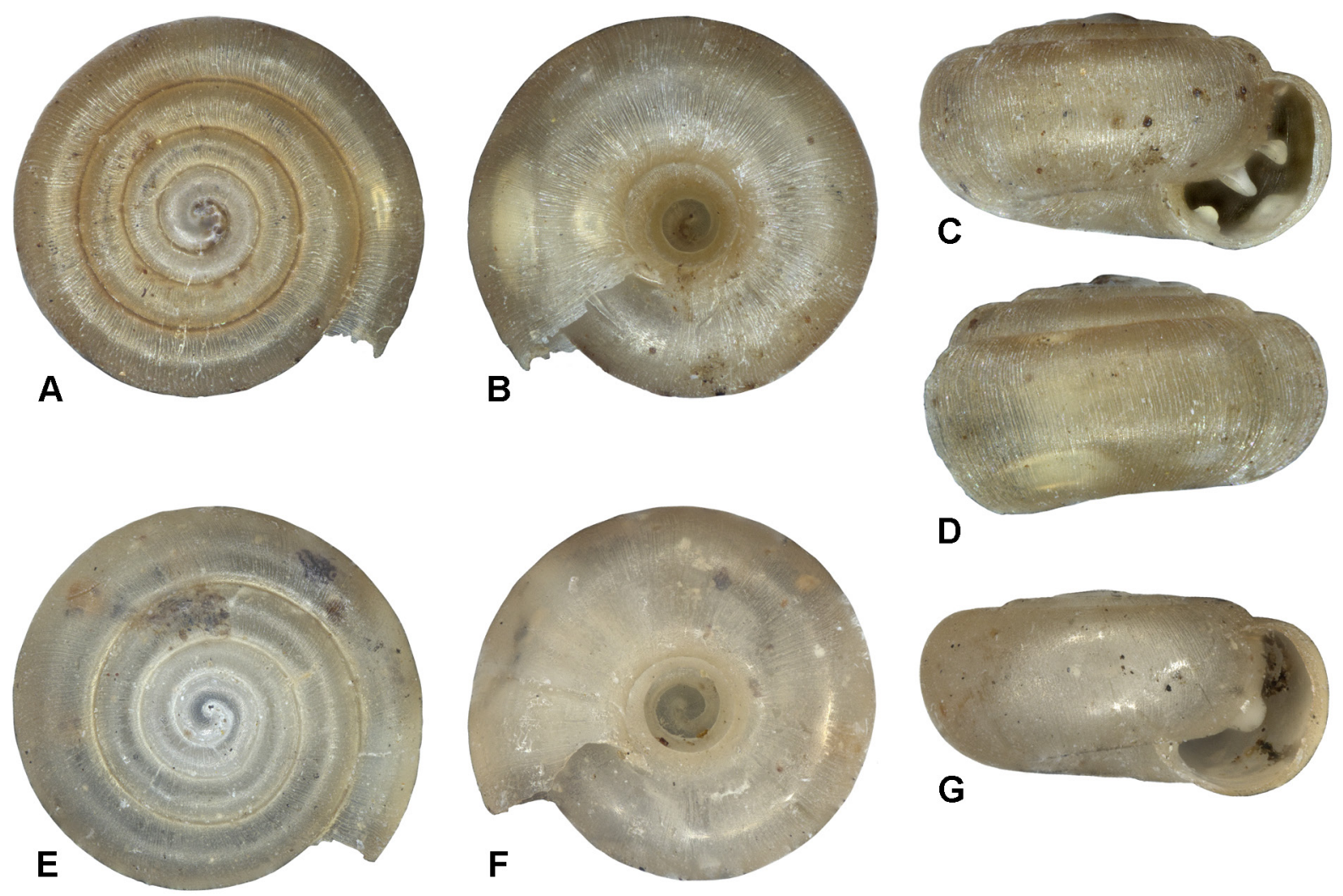

D

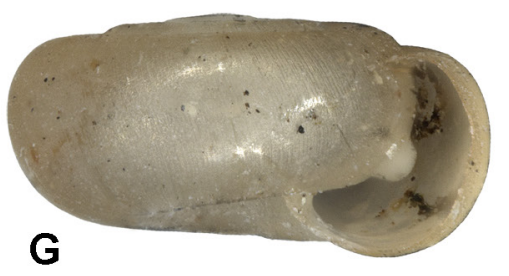

Fig. 7. Shells of Afrodonta species. A-D. Afrodonta pentodon sp. nov., holotype, diameter $1.45 \mathrm{~mm}$ (NMSA V6950/T4239). E-G. Afrodonta unilamellaris Connolly, 1933, Mfongosi, KwaZulu-Natal, diameter $1.52 \mathrm{~mm}$ (NMSA A9186). 
Afrodonta unilamellaris - Connolly 1939: 250, text-fig. 19(6). — Solem 1970: 360. — Herbert \& Kilburn 2004: 248, text-fig.

\section{Diagnosis}

Shell small, spire weakly raised, whorls somewhat flat-sided; protoconch smooth, at most microscopically shagreened (diameter $\pm 375 \mu \mathrm{m}$ ); teleoconch texture silky; sculpture comprising simple, very fine and close-set axial riblets of alternating strength; spiral sculpture of fine indistinct threads in riblet intervals; parietal region with a single rounded in-running ridge-like lamella (occasionally the crest divided by a groove); baso-columellar and palatal regions lacking dentition; umbilicus relatively narrow. Shell buff to pale ochre when fresh; diameter up to $1.6 \mathrm{~mm}$.

\section{Material examined}

Holotype

SOUTH AFRICA• KwaZulu-Natal, Mfongosi; W.E. Jones leg.; NHMUK 1931.6.4.3.

\section{Paratypes}

SOUTH AFRICA • 6 specimens; same collection data as for holotype; NHMUK 1937.12.30.2795 to 2800 .

\section{Other material}

SOUTH AFRICA - KwaZulu-Natal • 5 specimens; KwaZulu-Natal, Mfongosi; $28.713^{\circ} \mathrm{S}, 30.805^{\circ}$ E; W.E. Jones leg.; NMSA A9186 1 specimen; same collection data as for preceding; NMSA A9194 • 16 specimens; same collection data as for preceding; NMSA A9195.

\section{Distribution and conservation}

A narrow-range endemic (Fig. 6), known only from the Mfongosi area ( $\pm 500 \mathrm{~m}$ a.s.l.) in the Thukela River valley below Kranskop, KwaZulu-Natal; no accurate habitat data available. This area is not afforded any formal protection and is threatened by impacts related to subsistence agriculture.

\section{Remarks}

Unlikely to be confused with any other species. The original samples collected by W.E. ['Mamba'] Jones remain the only ones known. The Mfongosi area contains a number of small, isolated limestone bodies belonging to the Ntingwe Group (Martini 1987) from which other narrow-range endemic land snails are known, e.g., Anisoloma falconiana (Pilsbry, 1929) and Gulella leucocion Connolly, 1929. Herbert \& Kilburn (2004: 53) discussed the interesting history of this locality and the original collector.

\section{Genus Amatholedonta gen. nov. urn:1sid:zoobank.org:act:18997261-62F4-455F-BE93-F786B3F27553}

\section{Type species}

Afrodonta bimunita Connolly, 1939.

\section{Diagnosis}

Shell relatively large (max. diameter $\pm 2.0 \mathrm{~mm}$ ), biconcave with deeply sunken spire; umbilicus moderate to wide; whorls deep and tightly coiled, strongly rounded apically and basally, less so at periphery; last adult whorl not descendant. Protoconch smooth, apical cap noticeably swollen, almost circular; teleoconch with fine, close-set, axial riblets; riblets compound, composed of several periostracal lamellae; intervals between riblets with fine intermediary axial threads; spiral sculpture faint, mostly 
scarcely evident. Aperture narrowly lunate; parietal dentition absent; palatal region with 1-3 axially aligned rows of denticles set back up to $1 / 3$ whorl behind outer lip.

\section{Etymology}

From the Amathole Mountains, and donta: a contraction of Afrodonta. Gender feminine.

\section{Remarks}

Amatholedonta gen. nov. is proposed for two deeply biconcave species from neighbouring regions in the Amathole Mountains. The genus is characterised by the deep shell, fine axial teleoconch sculpture, smooth globose protoconch and episodic deposition of palatal denticles. Species of Costulodonta gen. nov. may be similar, but they have less deep whorls, a flat or slightly raised spire, and a costate protoconch.

\section{Key to species of Amatholedonta gen. nov.}

1 Rows of palatal teeth each with 5-6 denticles

A. bimunita gen. et comb. nov.

- Rows of palatal teeth each with three denticles A. fordycei gen. et sp. nov.

Amatholedonta bimunita (Connolly, 1939) gen. et comb. nov.

Figs 8A-D, 9, 18C-D

Afrodonta bimunita Connolly, 1939: 256, text-fig. 19(10), pl. 6, figs 1-4.

Afrodonta bimunita - Solem 1970: 363.

\section{Diagnosis}

Shell relatively large, deeply biconcave; protoconch with globose apical cap, smooth (diameter $\pm 305 \mu \mathrm{m}$ ); teleoconch sculptured by distinct, close-set, compound axial riblets; intervals between riblets with numerous fine intermediary axial threads; spiral sculpture of indistinct microscopic spiral threads, usually strongest in umbilicus. Aperture narrowly lunate; parietal dentition lacking; palatal region with 1-3 axially aligned rows of small denticles set back $1 / 8$ to $1 / 3$ whorl behind outer lip, outermost row sometimes visible through aperture, other rows apparent only through translucent shell; each row with up to 5 denticles, with an additional small baso-columellar denticle (easily overlooked); number of denticles and position of rows somewhat variable and related to degree of development; those below periphery more elongate, those above more rounded. Shell translucent, honey-brown when fresh; diameter up to $2.0 \mathrm{~mm}$.

\section{Material examined}

\section{Holotype}

SOUTH AFRICA • E. Cape, Amatola [Amathole] Mtns, Hogsback; R.F. Lawrence leg.; SAMC MBA008142.

\section{Paratype}

SOUTH AFRICA • 1 specimen; same collection data as for holotype; NHMUK 1937.12.30.2726.

\section{Other material}

SOUTH AFRICA - E. Cape - 14 specimens; Hogsback, environs of Madonna and Child waterfall; $32.60703^{\circ}$ S, $26.96268^{\circ}$ E; 1075 m a.s.1.; 25 Jan. 2002; D.G. Herbert, M. Bursey and G. Redman leg.; indigenous forest, under log; NMSA V9795 - 1 specimen; Hogsback, Madonna and Child Falls walk; $32.60701^{\circ} \mathrm{S}, 26.96257^{\circ}$ E; 1075 m a.s.1.; 6 Apr. 2014; D.G. Herbert, L.S. Davis and M. Cole leg.; station 14-02, southern mistbelt forest, in leaf-litter; NMSA W9740 • 5 specimens; Hogsback, Madonna and 

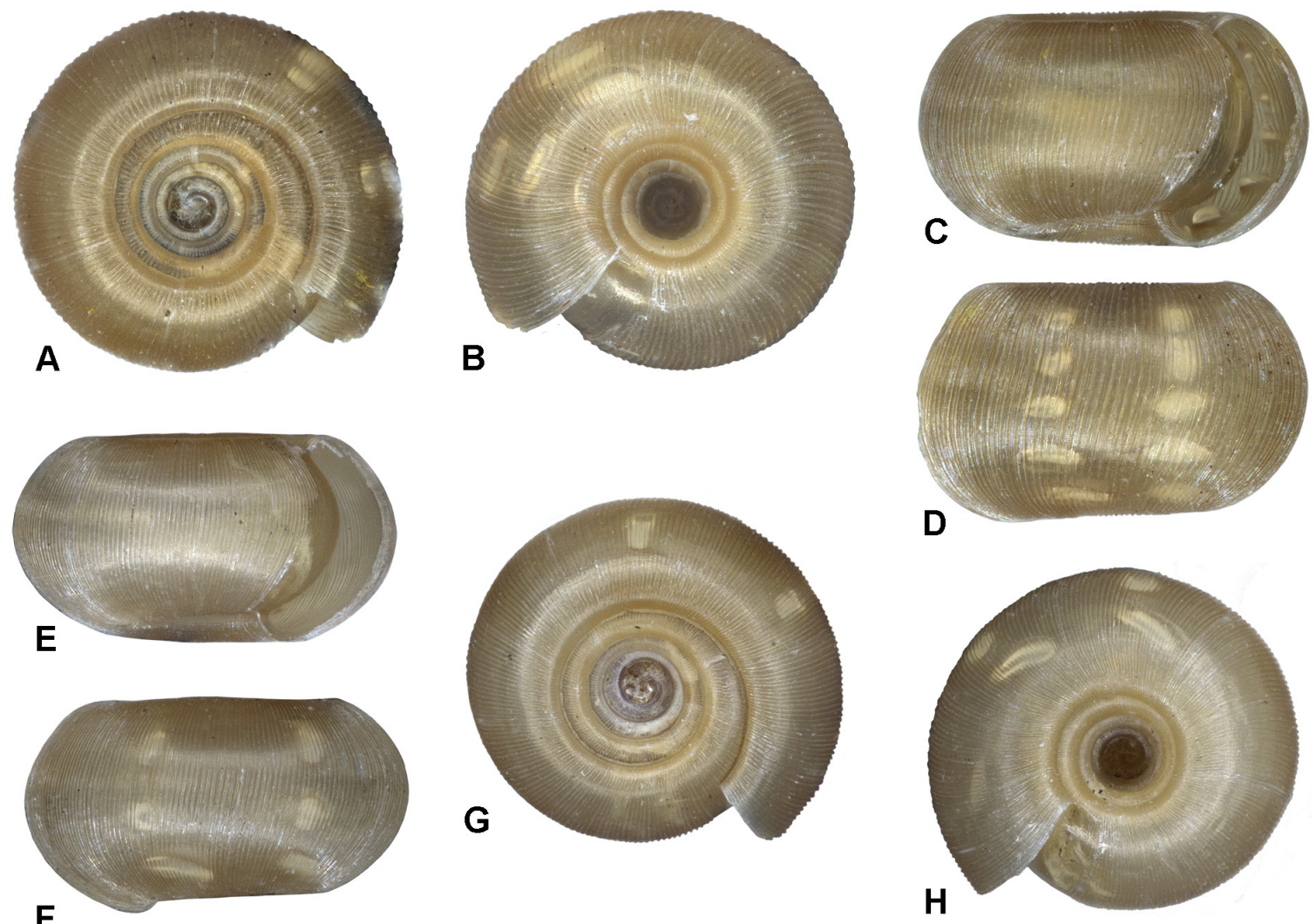

D
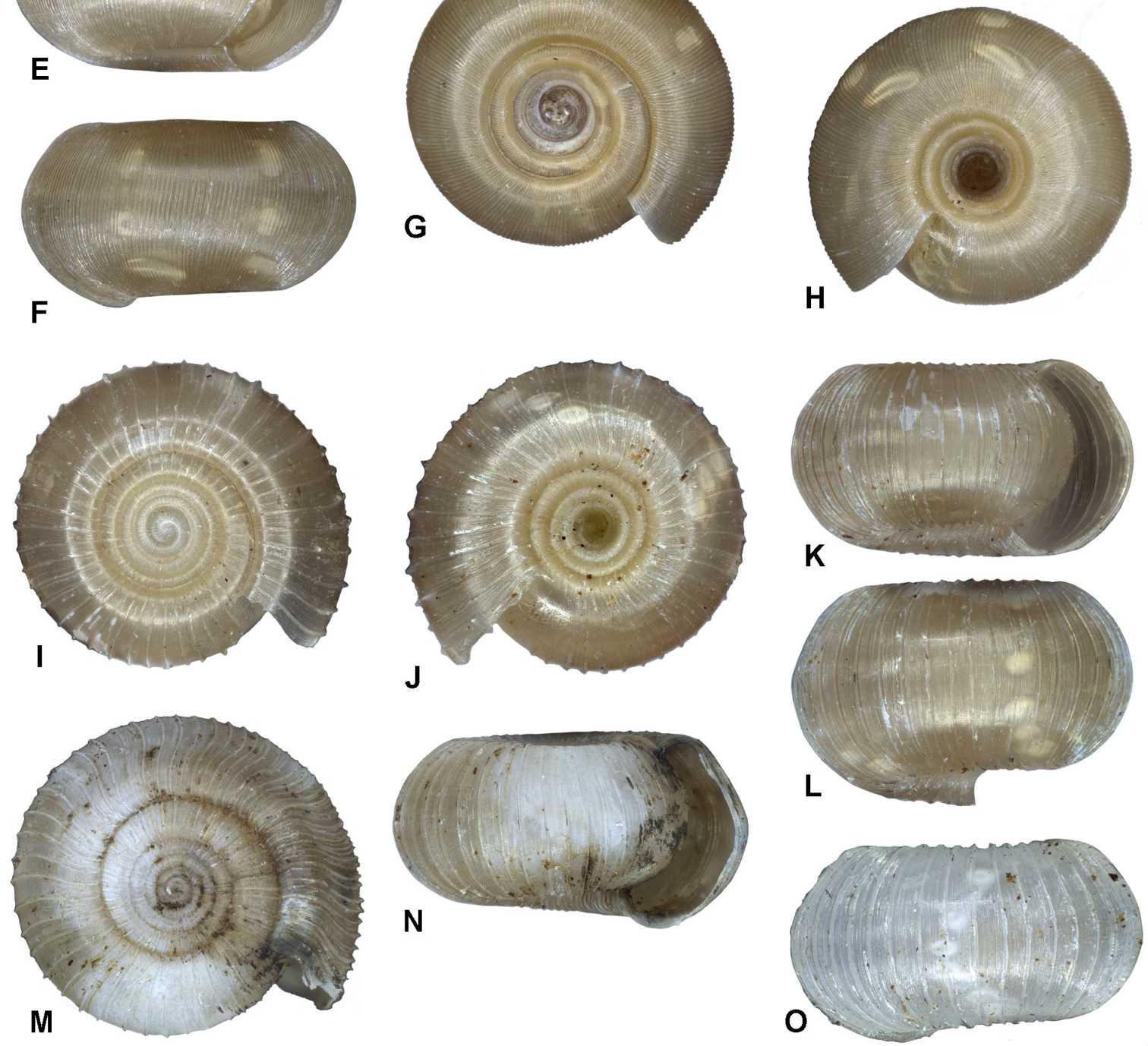

Fig. 8. Shells of Amatholedonta gen. nov. and Biomphalodonta gen. nov. species. A-D. Amatholedonta bimunita (Connolly, 1939) gen. et comb. nov., Hogsback, E. Cape, diameter $2.0 \mathrm{~mm}$ (NMSA W6658). E-H. Am. fordycei gen. et sp. nov., holotype, diameter $1.84 \mathrm{~mm}$ (NMSA W6668/T4270). I-L. Biomphalodonta forticostata gen. et sp. nov., holotype, diameter $2.13 \mathrm{~mm}$ (NMSA V6949/T4261). M-O. B. forticostata gen. et sp. nov., paratype, large specimen, diameter 2.7 mm (NMSA V4886/T4262). 
Child area; $32.60611^{\circ} \mathrm{S}, 26.96250^{\circ} \mathrm{E} ; 1075 \mathrm{~m}$ a.s.1.; 31 Dec. 2008; indigenous forest; M. and K. Cole leg.; NMSA W6658 • 3 specimens; same collection data as preceding; ELM D16119 • 2 specimens; Hogsback Forest Reserve; $32.60^{\circ} \mathrm{S}, 26.93^{\circ}$ E; $1300 \mathrm{~m}$ a.s.l.; 19 Feb. 1997; D. Barraclough and S. James leg.; indigenous forest, sorted from dried leaf-litter sample; NMSA V4876 1 specimen; Hogsback, Hobbiton Forest; $32.59658^{\circ}$ S, $26.95749^{\circ}$ E; 1180 m a.s.l.; 6 Apr. 2014; D.G. Herbert, M. Cole and L.S. Davis leg.; station 14-01, southern mistbelt forest, in leaf-litter; NMSA W9751 - 4 specimens; Hogsback; 32.58935 ${ }^{\circ}$ S, $26.93563^{\circ}$ E; 1220 m a.s.1.; 21 Jan. 2005; A. Moussalli and D. Stuart-Fox leg.; indigenous forest, in leaf-litter; NMSA W2841 • 1 specimen; same collection data as preceding; NMSA W4464 6 specimens; Stutterheim, Kologha Forest, waterfall walk from picnic site; $32.53387^{\circ}$ S, 27.43083 E; 22 Dec. 2009; M. Cole leg.; ELM D16196 • 5 specimens; Stutterheim, Kologha Forest, forest drive near Protea Hill; 32.5558 ${ }^{\circ}$ S, $27.3175^{\circ}$ E; 26 Jan. 2009; M. Cole leg.; ELM D16161.

\section{Distribution and conservation}

A narrow-range endemic (Fig. 9), known only from the Hogsback to Stutterheim area in the Amathole Mountains, E. Cape, at 1075-1300 m a.s.l.; in leaf-litter of southern mistbelt forest. Both the Hogsback and Kologha forests are formally protected areas.

\section{Remarks}

Resembles its congener Amatholedonta fordycei gen. et sp. nov.; however, in the latter the axial sculpture is finer and there are only three denticles in each of the rows of palatal teeth. Biomphalodonta forticostata gen. et sp. nov. has a similarly shaped shell, but the axial sculpture is much coarser, the rows of palatal

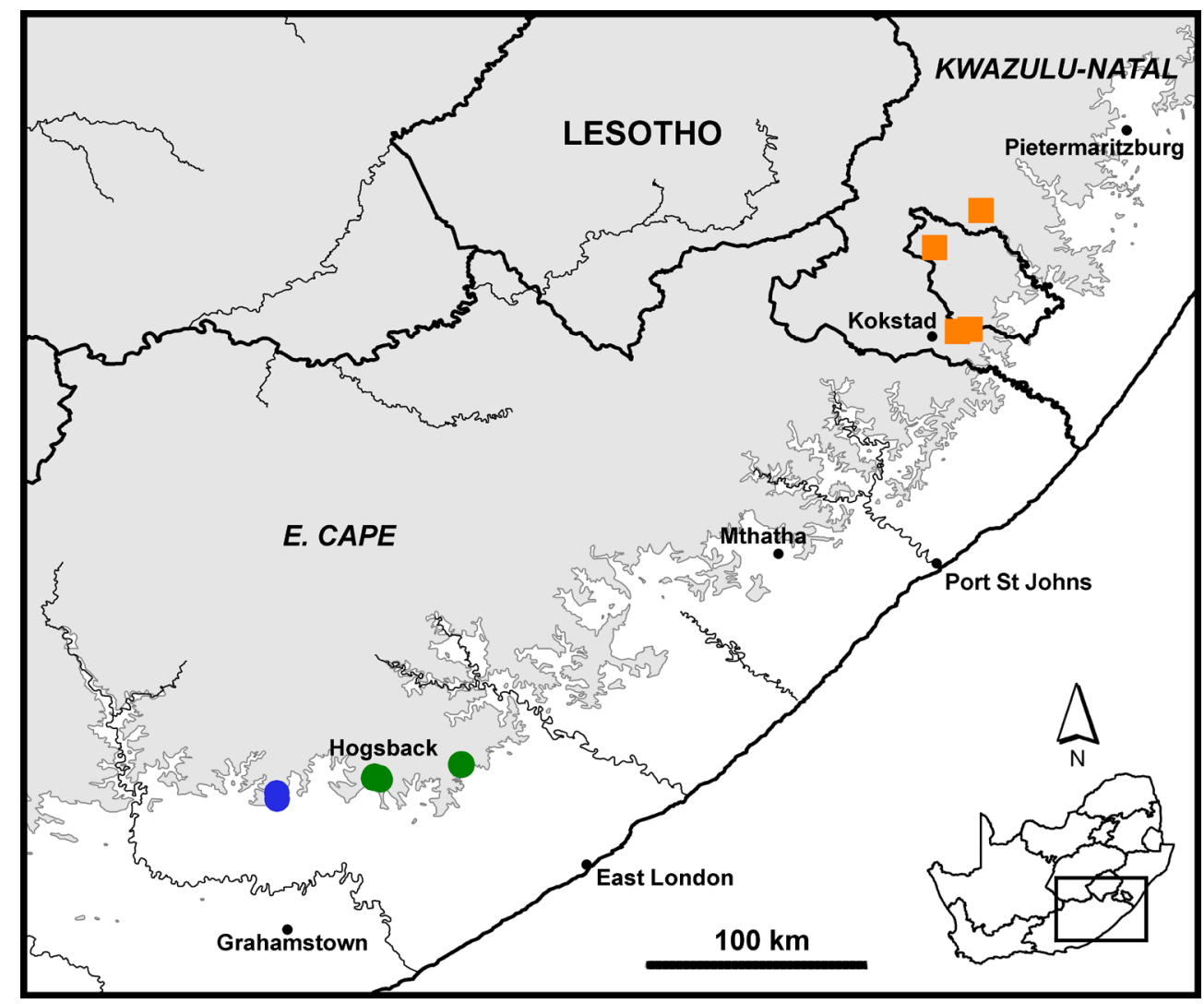

Fig. 9. Distribution of Amatholedonta bimunita (Connolly, 1939) gen. et comb. nov. (green circles), Am. fordycei gen. et sp. nov. (blue circles) and Biomphalodonta forticostata gen. et sp. nov. (orange squares). Contour at $1000 \mathrm{~m}$. 
denticles are more distinctly C-shaped and the minute denticle at the junction of the basal and columellar lips is lacking. In addition, the protoconch of $B$. forticostata gen. et sp. nov. has distinct axial sculpture.

Whereas Connolly (1939) cited six palatal denticles per row in Am. bimunita gen. et comb. nov., Solem (1970) cited only five. This discrepancy indicates either that Solem overlooked the minute basocolumellar denticle or that the NHMUK specimen he examined had fewer denticles than the holotype described by Connolly (this is sometimes the case). Since Solem described the lowest denticle as being the most posterior and the middle two the most anterior, this would suggest that he overlooked the basocolumellar denticle, which is slightly anterior to the lowest palatal denticle.

Amatholedonta fordycei gen. et sp. nov. urn:1sid:zoobank.org:act:750BDD68-09E8-4830-8C54-EE7F0225323F

Figs $8 \mathrm{E}-\mathrm{H}, 9,18 \mathrm{E}-\mathrm{F}$

\section{Diagnosis}

Shell relatively large, biconcave with deep, tightly coiled whorls; spire distinctly sunken; protoconch smooth, globose; teleoconch sculptured by fine, close-set axial riblets, spiral sculpture virtually obsolete; aperture narrow, crescent-shaped, lacking parietal and columellar dentition; palatal region with 1-2 axially aligned rows of denticles set back $1 / 6$ and $1 / 3$ whorl behind outer lip, visible only by transparency; each row with three denticles, situated at, below, and above periphery; umbilicus of moderate width and deep, V-shaped. Shell translucent, straw-brown; diameter up to $2.0 \mathrm{~mm}$.

\section{Etymology}

Named after the type locality, Fort Fordyce, E. Cape.

\section{Material examined}

\section{Holotype}

SOUTH AFRICA • E. Cape, Fort Beaufort area, Fort Fordyce Nature Reserve; $32.69556^{\circ} \mathrm{S}, 26.48556^{\circ} \mathrm{E}$; 1120 m a.s.1.; 30 Dec. 2008; M. and K. Cole leg.; south facing indigenous forest, under logs; diameter $1.84 \mathrm{~mm}$, height $1.10 \mathrm{~mm}$; NMSA W6668/T4270.

\section{Paratypes}

SOUTH AFRICA - E. Cape $\cdot 2$ specimens; same collection data as for holotype; NMSA P1020/T4271 - 8 specimens; NW of Fort Beaufort, Fort Fordyce Nature Reserve; $32.667^{\circ} \mathrm{S}, 26.483^{\circ} \mathrm{E} ; \pm 1100 \mathrm{~m}$ a.s.1.; 8 Jul. 2001; C. Symes leg.; in forest leaf-litter; NMSA V9343/T4266 • 11 specimens; Fort Fordyce Nature Reserve, kloof with sheer krantz; 32.68808 S, 26.51304 E; 6 Oct. 2009; M. Cole leg.; ELM D16076/T168 20 specimens; Fort Fordyce Nature Reserve, near Harris Hut; $32.68342^{\circ} \mathrm{S}, 26.47670^{\circ} \mathrm{E}$; 5 Oct. 2009; M. Cole leg.; ELM D16087/T169.

\section{Description}

Shell relatively large, diameter up to $2.0 \mathrm{~mm}, \mathrm{H} / \mathrm{D}$ ratio \pm 0.55 , biconcave with deep, tightly coiled whorls; spire distinctly sunken; last adult whorl not descendant; suture strongly indented, and apical and basal portions of whorls strongly convex, peripheral portion evenly rounded. Protoconch comprising globose apical cap plus approx. 1.0 whorl; diameter $\pm 325 \mu \mathrm{m}$; smooth. Teleoconch of up to 3.75 whorls; sculptured by fine, close-set axial riblets, with intervals 1.0-1.5 times their width at whorl periphery; spiral sculpture virtually obsolete. Umbilicus of moderate width and deep, V-shaped. Aperture narrow, crescent-shaped, but apical and basal limits rounded; parietal and columellar dentition lacking; palatal region with 1-2 axially aligned rows of denticles set back $1 / 6$ and $1 / 3$ whorl behind outer lip, not visible through aperture and apparent only through translucent shell; each row with three denticles, situated at, 
below and above periphery, the upper two rounded (uppermost sometimes axially elongate), the lower one an elongate, in-running ridge. Shell translucent, straw-brown.

\section{Distribution and conservation}

A narrow-range endemic (Fig. 9), known only from the Fort Fordyce Nature Reserve, near Fort Beaufort, E. Cape, at approx. $1100 \mathrm{~m}$ a.s.1.; in leaf-litter of southern mistbelt forest. Fort Fordyce Nature Reserve is a formally protected area managed by Eastern Cape Parks and Tourism Agency.

\section{Remarks}

Amatholedonta fordycei gen. et sp. nov. resembles Am. bimunita gen. et comb. nov. from the neighbouring Hogsback region. It differs from that species in having much finer axial sculpture and a somewhat less deeply sunken spire. In addition, the palatal dentition contains only three denticles per row (instead of 5-6), of which the most basal one is markedly more elongate.

Genus Biomphalodonta gen. nov.

urn:1sid:zoobank.org:act:CE2A2B8F-D281-4E81-BF8D-5A705868D71A

\section{Type species}

Biomphalodonta forticostata gen. et sp. nov.

\section{Diagnosis}

Shell relatively large (max. diameter $2.7 \mathrm{~mm}$ ), biconcave with deeply sunken spire; umbilicus wide; whorls deep and tightly coiled, strongly rounded apically and basally, less so at periphery; last adult whorl not descendant. Protoconch with fine, close-set, regularly spaced axial riblets; riblets crisp and simple. Teleoconch with relatively coarse, widely spaced, lamellate axial riblets; intervals between riblets with numerous, fine, intermediary axial threads and even finer spiral threads. Aperture narrowly lunate; parietal dentition absent; palatal region with 1-2 axially aligned rows of denticles set back up to $1 / 2$ whorl behind outer lip.

\section{Etymology}

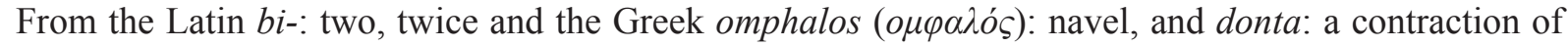
Afrodonta; with reference to the biconcave shell morphology. Gender feminine.

\section{Remarks}

Biomphalodonta gen. nov. is proposed for a single highly characteristic, range-restricted species. The axially costate protoconch is similar to that found in Costulodonta gen. nov., but the deep, relatively large, biconcave shell and coarse teleoconch sculpture set it apart from members of that genus. The shape of the shell and the iterodont palatal dentition resemble those of Amatholedonta gen. nov., but in that genus the protoconch is smooth and globose, and the teleoconch sculpture much finer.

A number of small, edentate charopid species currently referred to Trachycystis Pilsbry, 1893 are conchologically similar to B. forticostata gen. et sp. nov., except for their lack of apertural dentition. These include, inter alia, Trachycystis bathycoele (Melvill \& Ponsonby, 1892) and T. bifoveata Connolly, 1932. Further study is needed in order to establish whether these also belong to Biomphalodonta gen. nov. It may be that the presence/absence of apertural dentition is of limited phylogenetic significance and that the genus contains both dentate and edentate species. 


\section{Biomphalodonta forticostata gen. et sp. nov. urn:1sid:zoobank.org:act:83C8FFD5-F9B7-493E-A4E6-2E14B7B2AF98}

Figs $8 \mathrm{I}-\mathrm{O}, 9,18 \mathrm{G}-\mathrm{H}$

\section{Diagnosis}

Shell relatively large, biconcave with deep, tightly coiled whorls; spire deeply sunken; protoconch sculptured by fine axial riblets; teleoconch with relatively strong, widely spaced axial ribs, their intervals with microscopic axial and even finer spiral threads; aperture narrow, crescent-shaped, lacking parietal and columellar dentition; palatal region with 1-2 axially aligned rows of small denticles set back $1 / 4$ and $1 / 2$ whorl behind outer lip, visible only by transparency; rows broadly C-shaped, each with up to 6 denticles; umbilicus wide and deep, V-shaped. Shell somewhat translucent, typically pale straw-brown, but occasional specimens milky-white; diameter up to $2.7 \mathrm{~mm}$.

\section{Etymology}

From the Latin fortis: strong and costa, costata: a rib, ribbed; with reference to the coarse axial sculpture.

\section{Material examined}

\section{Holotype}

SOUTH AFRICA • KwaZulu-Natal, Ngele Forest; $30.533^{\circ}$ S, $29.633^{\circ}$ E; 1350 m a.s.1.; 3 Mar. 1997; D.G. Herbert leg.; mistbelt Podocarpus forest, sorted from dried leaf-litter sample; diameter $2.13 \mathrm{~mm}$, height $1.20 \mathrm{~mm}$; NMSA V6949/T4261.

\section{Paratypes}

SOUTH AFRICA - KwaZulu-Natal 7 specimens; same collection data as for holotype; NMSA V4886/ T4262 • 1 specimen; Hlabeni Forest; $29.975^{\circ}$ S, $29.742^{\circ}$ E; 1350 m a.s.1.; 24 Aug. 1997; C. Symes leg.; mistbelt Podocarpus forest, in leaf-litter sample; NMSA V5221/T4263 • 1 specimen; Ngele Forest; $30.525^{\circ} \mathrm{S}, 29.692^{\circ}$ E; 1300 m a.s.l.; 14 Nov. 1995; L.S. Davis and D.G. Herbert leg.; mistbelt Podocarpus forest, in leaf-litter; NMSA V2069/T4260.

\section{Other material}

SOUTH AFRICA - KwaZulu-Natal - 1 specimen; Creighton area, Riverside, Kwahoha Forest; $30.1472^{\circ} \mathrm{S}, 29.52778^{\circ}$ E; ca 1300 m a.s.1.; 27 Jan. 2001; C. Symes leg.; mistbelt Podocarpus forest, in leaf-litter; NMSA V9173 • 1 specimen; Ngele Forest; $30.533^{\circ} \mathrm{S}, 29.633^{\circ} \mathrm{E} ; 1350 \mathrm{~m}$ a.s.1.; 14 Nov. 1995 ; D.G. Herbert and L.S. Davis leg.; mistbelt Podocarpus forest, in leaf-litter; NMSA V5187.

\section{Description}

Shell relatively large, diameter up to $2.7 \mathrm{~mm}, \mathrm{H} / \mathrm{D}$ ratio \pm 0.56 ; biconcave with deep, tightly coiled whorls; spire deeply sunken; last adult whorl not descendant; suture strongly indented, and apical and basal portions of whorls strongly convex, peripheral portion less so; largest individuals with a shallow supra-peripheral indentation in second half of last adult whorl and a weakly angled periphery (Fig. 8M-N). Protoconch comprising apical cap plus 0.75 whorl; diameter $\pm 340 \mu \mathrm{m}$; sculptured by fine axial riblets, relatively widely spaced on apical cap, becoming progressively more close-set toward junction with teleoconch. Teleoconch of up to 4.0 whorls, its sculpture coarse, comprising relatively strong, widely spaced axial ribs, their intervals with close-set microscopic axial threads; even finer, close-set microscopic spiral threads also evident in fresh specimens; axial ribs for the most part regularly spaced, but becoming less regular, more close-set and noticeably sinuous in last quarter whorl of largest specimens. Umbilicus wide and deep, V-shaped, but suture indented and whorl margins strongly convex. Aperture narrow, crescent-shaped, but apical and basal limits rounded; parietal and columellar dentition lacking; palatal region with 1-2 axially aligned rows of small denticles set back $1 / 4$ and $1 / 2$ 
whorl behind outer lip, not visible through aperture and apparent only through translucent shell; each row with up to 6 denticles; number and alignment of denticles somewhat variable and related to degree of development; those nearest periphery usually slightly more anterior and rows thus broadly C-shaped at full development. Shell somewhat translucent, typically pale straw-brown, but occasional specimens milky-white.

\section{Distribution and conservation}

A narrow-range endemic (Fig. 9), known only from south-western KwaZulu-Natal, between Kokstad and Donnybrook, at 1300-1400 m a.s.1.; living in leaf-litter of southern mistbelt forest. Although forests in this area are theoretically protected, access is completely uncontrolled and they are often in close proximity to exotic timber plantations and thus exposed to threats associated with disturbance and alien plant invasion.

\section{Remarks}

The relatively large and deeply biconcave shell of this species resembles those of Amatholedonta bimunita gen. et comb. nov. and Am. fordycei gen. et sp. nov. The coarse axial sculpture of the present species, however, renders it distinctive. Additionally, in Am. bimunita gen. et comb. nov. the palatal dentition, as seen by transparency, comprises 1-3 more or less vertical rows of five denticles (occasionally four), the lower three in each row more elongate. A minute sixth denticle is also present at the junction of the basal and columellar lips, but is easily overlooked. In Am. fordycei gen. et sp. nov. there are similarly 1-3 axially aligned rows of denticles, but each has only three denticles, the lowest of which is markedly more elongate. In neither Am. bimunita gen. et comb. nov. nor Am. fordycei gen. et sp. nov. is the protoconch axially ribbed. With a maximum diameter of $2.7 \mathrm{~mm}, B$. forticostata gen. et sp. nov. is the largest species of dentate charopid snail known to date from southern Africa.

Genus Costulodonta gen. nov. urn:1sid:zoobank.org:act:FC341D9C-2CC1-4B4C-8E9B-629F7913DD46

\section{Type species}

Afrodonta acinaces Connolly, 1933.

\section{Diagnosis}

Shell small (max. diameter $\pm 1.8 \mathrm{~mm}$ ), spire flat or weakly raised; umbilicus moderate to wide; whorls tightly coiled, strongly rounded apically and basally, less so at periphery; last adult whorl weakly descendant. Protoconch with fine, close-set, regularly spaced axial riblets; riblets crisp and simple, often with indistinct traces of irregular spiral threads in their intervals. Teleoconch also with fine, closeset axial riblets, but these coarser than those on protoconch; riblets compound, composed of several periostracal lamellae; intervals between riblets with finer intermediary axial threads; spiral sculpture absent or restricted to microscopic spiral threads. Aperture obliquely lunate, slightly wider basally; aperture variously furnished with parietal and palatal dentition in the form of denticles and/or in-running lamellae/ridges.

\section{Etymology}

From the Latin costa: a rib, diminutive costula, and donta: a contraction of Afrodonta; with reference to the axial sculpture of the protoconch. Gender feminine.

\section{Remarks}

Costulodonta gen. nov. is proposed for a group of species which share a costate protoconch and relatively coarse teleoconch sculpture of compound axial riblets with multiple fine intermediary axial threads. 
The genus is known only from the afrotemperate and mistbelt forests of the KwaZulu-Natal interior. Members of Afrodonta differ from Costulodonta gen. nov. in having a smooth protoconch and a silky teleoconch sculpture comprising simple axial riblets of alternating strength.

\section{Key to species of Costulodonta gen. nov.}

1 Parietal dentition absent C. bidens gen. et sp. nov.

- Parietal dentition present 2

2 Parietal region with a single low, in-running ridge C. trilamellaris gen. et comb. nov.

- Parietal region with two lamellae or one lamella plus an in-running row of denticles 3

3 Palatal region lacking dentition; baso-columellar region with a single, low denticle

- Palatal region dentate; baso-columellar denticle also present 4

4 Palatal region with 3-4 denticles; upper parietal tooth an in-running lamella

C. pluridens gen. et sp. nov.

- Palatal region with two broad, deep-set in-running ridges; upper parietal comprising an in-running row of two or more denticles C. acinaces gen. et comb. nov.

Costulodonta acinaces (Connolly, 1933) gen. et comb. nov. Figs 10A-D, 11, 18I-J

Afrodonta acinaces Connolly, 1933; 149, text-fig. 1(8), pl. 7, figs 12-15.

Afrodonta acinaces - Connolly 1939: 253, text-fig. 19(8). — Solem 1970: 355. — Herbert \& Kilburn 2004: 250, text-fig.

\section{Diagnosis}

Shell small, spire flat or at most fractionally raised; protoconch with close-set axial riblets (diameter $\pm 410 \mu \mathrm{m}$ ); teleoconch sculpture of compound axial riblets with 3-4 intermediary axial threads; spiral sculpture faint; parietal region with an in-running lamella well below mid-whorl (crest sometimes nodular), plus an in-running row of 2-4 small denticles at mid-whorl, sometimes joined by a low ridge (at most two denticles visible though aperture); baso-columellar region with a deeply recessed, inrunning ridge-like denticle, scarcely visible through aperture; palatal region with two in-running ridges, narrow at first but broadening internally and each grooved medially by a furrow; an additional, deeply recessed, narrow, ridge-like denticle present just below suture; umbilicus of moderate width. Shell pale corneous brown; diameter up to $1.6 \mathrm{~mm}$.

\section{Material examined}

Holotype

SOUTH AFRICA • KwaZulu-Natal, Van Reenen; Mar. 1918; H.C. Burnup leg.; NHMUK 1931.6.4.2.

Paratypes

SOUTH AFRICA • 12 specimens; same collection data as for holotype; NHMUK 1937.12.30.2711 to 2722.

\section{Other material}

SOUTH AFRICA - KwaZulu-Natal • 5 specimens; Van Reenen; 28.40 S, 29.39 E; Mar. 1918; H.C. Burnup leg.; NMSA A9182 • 71 specimens; same collection data as for preceding; NMSA A9183 • 
10 specimens; same collection data as for preceding; NMSA A9185 3 specimens; same collection data as for preceding; NMSA A9208・15 specimens; same collection data as for preceding; NMSA A9210.

\section{Distribution and conservation}

A narrow-range endemic (Fig. 11), known only from the vicinity of Van Reenen, KwaZulu-Natal, no accurate altitude or habitat data available, presumably in leaf-litter of northern afrotemperate forest at 1500-1800 m a.s.1. Forested habitats in nature reserves along the Free State/KwaZulu-Natal border (e.g. Ingula Nature Reserve) need to be surveyed in the hope of finding extant colonies of this species in formally protected areas.
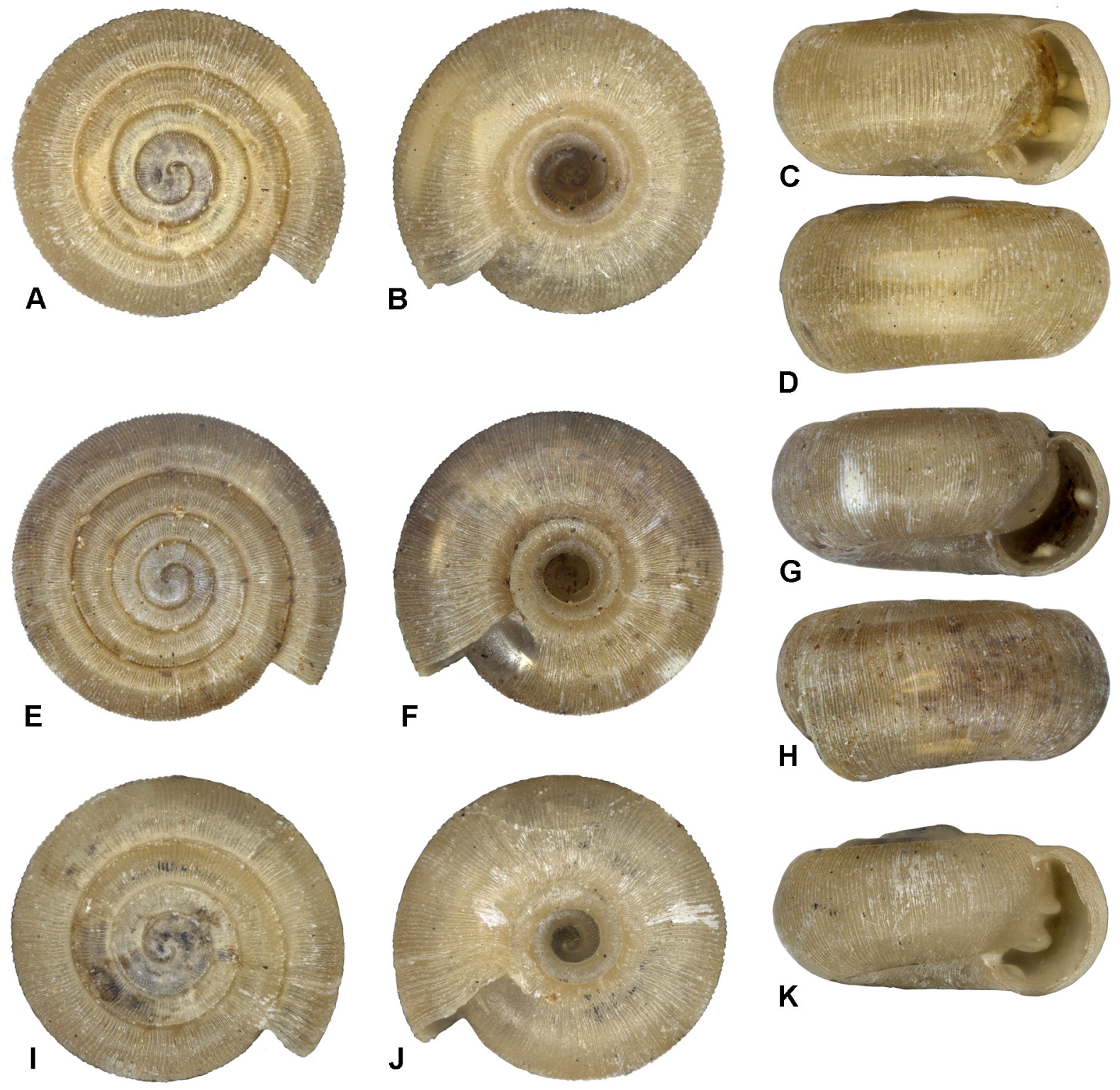

Fig. 10. Shells of Costulodonta gen. nov. species. A-D. C. acinaces (Connolly, 1933) gen. et comb. nov., Van Reenen, KwaZulu-Natal, diameter 1.39 mm (NMSA A9183). E-H. C. bidens gen. et sp. nov., holotype, diameter 1.65 mm (NMSA V5678/T4264). I-K. C. burnupi (Connolly, 1933) gen. et comb. nov., Mkolombe Mtn, Weenen, KwaZulu-Natal, diameter 1.32 mm (NMSA A9187). 


\section{Remarks}

Connolly (1939) mentioned material from Mount Vengo (on the Zimbabwe/Mozambique border) collected by Bernard Cressy. No such material is in NMSA, but a single specimen is present in NHMUK (1937.12.30.2727). This is damaged and the apertural dentition is missing (J. Ablett pers. comm., Dec. 2019). As a result it is unidentifiable, but the external sculpture is somewhat coarser than in topotypic C. acinaces gen. et comb. nov. and it seems unlikely that it is conspecific therewith. Thus, the original samples collected by Henry Burnup remain the only ones known. Judging by the number of specimens in these samples, the species must be locally common.

Costulodonta bidens gen. et sp. nov.

urn:lsid:zoobank.org:act:C5C0F93F-7276-41F1-9B91-AB8C0578CB65

Figs 10E-H, 11, 18K-L

\section{Diagnosis}

Shell small, spire flat or at most slightly raised; protoconch for the most part sculptured by close-set axial riblets; teleoconch sculpture of close-set, compound axial riblets and microscopic spiral threads; aperture lacking parietal and columellar dentition; palatal region with two relatively small denticles, one at mid-whorl, the other basal. Shell translucent, corneous-brown to straw-brown when fresh; diameter up to $1.65 \mathrm{~mm}$.

\section{Etymology}

From the Latin bis, bi-: two, and dens: a tooth; with reference to the apertural dentition.

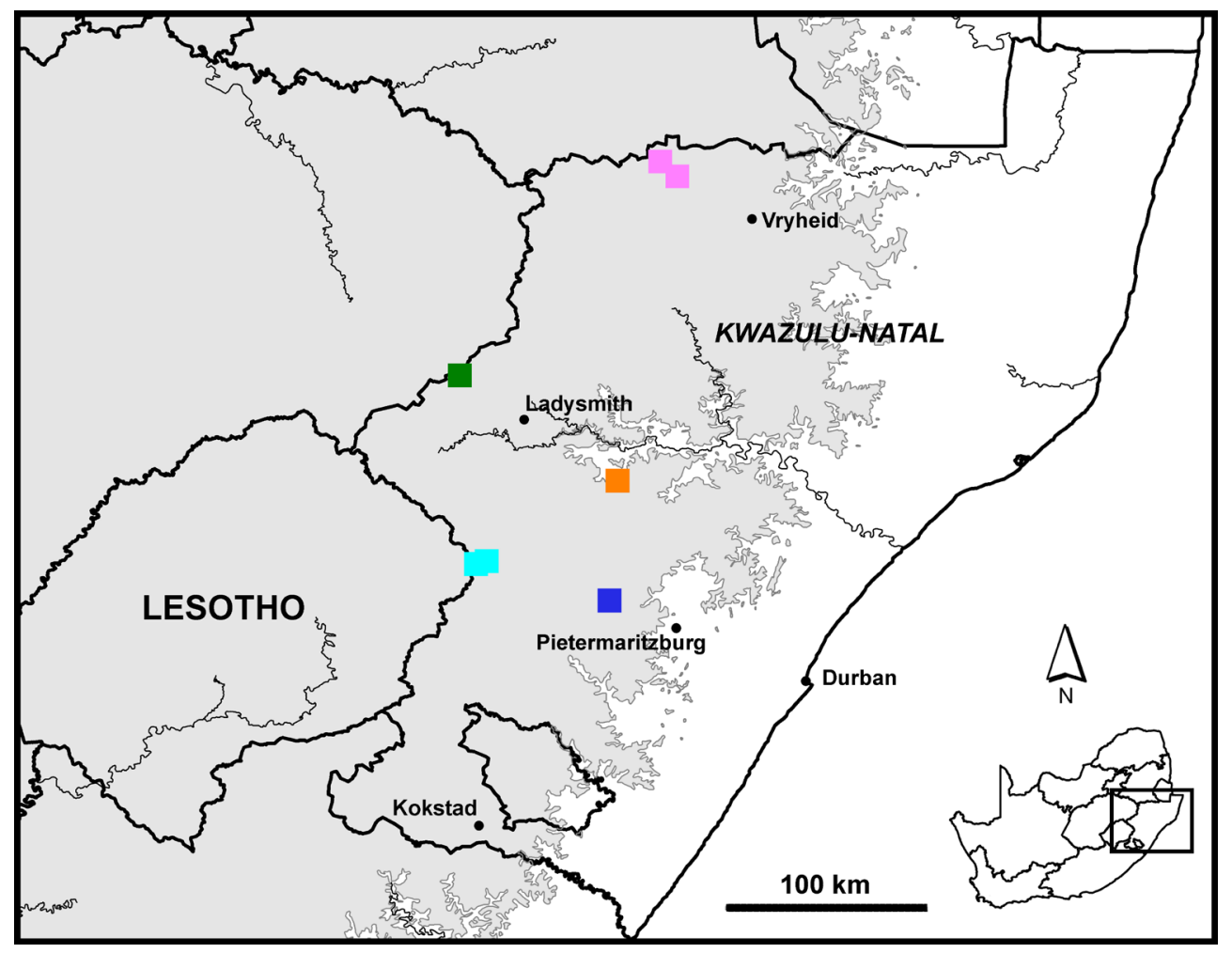

Fig. 11. Distribution of Costulodonta gen. nov. species. C. acinaces (Connolly, 1933) gen. et comb. nov. (green square), C. bidens gen. et sp. nov. (turquoise squares), C. burnupi (Connolly, 1933) gen. et comb. nov. (orange square) C. pluridens gen. et sp. nov. (pink squares), C. trilamellaris (Melvill \& Ponsonby, 1908) gen. et comb. nov. (royal blue square). Contour at $1000 \mathrm{~m}$. 


\section{Material examined}

\section{Holotype}

SOUTH AFRICA - KwaZulu-Natal, Giant's Castle Game Res., Yellow-Wood Forest; 29.300 ${ }^{\circ}$ S, 29.467 E; 15 Jul. 1997; Natal Parks Board (now Ezemvelo KwaZulu-Natal Wildlife) leg.; montane Podocarpus forest, in leaf-litter; diameter $1.65 \mathrm{~mm}$, height $0.83 \mathrm{~mm}$; NMSA V5678/T4264.

\section{Paratypes}

SOUTH AFRICA • 23 specimens; same collection data as for holotype; NMSA P1018/T4265.

\section{Other material}

SOUTH AFRICA • 2 specimens; KwaZulu-Natal, Giant's Castle, environs of Main Cave; $29.2856^{\circ}$ S, $29.5179^{\circ}$ E; 24 Sep. 2004; A. Moussalli and D. Stuart-Fox leg.; montane forest, in leaf-litter; NMSA W3106.

\section{Description}

Shell small, diameter up to $1.65 \mathrm{~mm}, \mathrm{H} / \mathrm{D}$ ratio \pm 0.50 ; spire flat or at most slightly raised; whorls tightly coiled; last adult whorl slightly descendant; suture indented, periphery evenly convex. Protoconch comprising apical cap plus approx. 0.75 whorl; diameter $\pm 330 \mu \mathrm{m}$; initially smooth, but for the most part sculptured by close-set axial riblets, with indistinct traces of irregular spiral threads. Teleoconch of up to 3.5 whorls; sculptured by distinct, close-set, compound axial riblets with 3-4 finer intermediary axial threads; intervals between riblets 1-2 times riblet width at whorl periphery; spiral sculpture of microscopic threads, strongest below suture. Umbilicus of moderate width. Aperture lunate, somewhat broader basally; parietal and columellar dentition lacking; palatal region with two relatively small denticles, one at mid-whorl, the other basal, set back approx. 1/8 whorl behind outer lip (sometimes weak). Shell translucent, corneous-brown to straw-brown when fresh.

\section{Distribution and conservation}

A narrow-range endemic (Fig. 11), known only from the Drakensberg foothills ('Little Berg') in the Giant's Castle area, KwaZulu-Natal, at approx. 1700-1800 m a.s.l.; in leaf-litter of northern afrotemperate forest. The area falls within the Giant's Castle Game Reserve, which is part of the Maloti-Drakensberg World Heritage Site. It is thus afforded a high degree of protection.

\section{Remarks}

Amongst its congeners, Costulodonta bidens gen. et sp. nov. is rendered distinctive on account of its relatively simple apertural dentition. Superficially the shell shows considerable resemblance to that of 'Trachycystis' contabulata Connolly, 1932, but that species is larger (diameter up to $2.4 \mathrm{~mm}$ ) and lacks apertural dentition. However, it does have a similarly sculptured protoconch and the two species may in fact be related. Though known to occur in the forests of the broader Giant's Castle area (Herbert \& Kilburn 2004), ' $T$ ' contabulata has, to date, not been found to co-occur with $C$. bidens gen. et sp. nov.

Costulodonta burnupi (Connolly, 1933) gen. et comb. nov.

Figs 10I-K, 11, 18M-N

Afrodonta burnupi Connolly, 1933: 148, text-fig. 1(7), pl. 7, figs 9-11.

Afrodonta burnupi - Connolly 1939: 252, text-fig. 19(7). — Solem 1970: 352, fig. 1e. — Herbert \& Kilburn 2004: 249, text-fig. 


\section{Diagnosis}

Shell very small, spire slightly raised; protoconch with close-set axial riblets (diameter $\pm 415 \mu \mathrm{m}$ ); teleoconch sculpture of compound axial riblets with 1-3 intermediary axial threads; spiral sculpture of indistinct microscopic threads, often scarcely evident; parietal region with two in-running lamellae (the upper one weaker and more deep-set); baso-columellar region with a deep-set, rounded, in-running ridge (sometimes missing, fide Connolly); palatal region lacking dentition; umbilicus of moderate width. Shell pale corneous brown; diameter up to $1.5 \mathrm{~mm}$.

\section{Material examined}

\section{Holotype}

SOUTH AFRICA • KwaZulu-Natal, Weenen, Mkolombe Mtn [uMkholombe]; $28.90^{\circ} \mathrm{S}, 30.14^{\circ} \mathrm{E}$; Mar. 1926; H.P. Thomasset leg.; NHMUK 1931.6.4.4.

\section{Paratypes}

SOUTH AFRICA - KwaZulu-Natal 22 specimens; Weenen, Tugela Estate; H.P. Thomasset leg.; Mar. 1926; NHMUK 1937.12.30.2728 to 2729. These specimens are not conspecific with the holotype and are also paratypes of Afrodonta connollyi Solem, 1970.

\section{Other material}

SOUTH AFRICA-KwaZulu-Natal • 3 specimens; Weenen, Mkolombe Mtn; Mar. 1926; H.P. Thomasset and G.J. Goodwin leg.; H.C. Burnup collection; NMSA A9187.

\section{Distribution and conservation}

A narrow-range endemic (Fig. 11), known only from the environs of Weenen, KwaZulu-Natal; no accurate altitude or habitat data available. Wooded habitats in Weenen Nature Reserve need to be surveyed in the hope of finding extant colonies of this species in a formally protected area.

\section{Remarks}

May be confused with Afrodonta connollyi, which sometimes has a baso-columellar ridge, but in that species the parietal lamellae are stronger, the protoconch is smooth, the teleoconch silky, the umbilicus narrower, and both parietal lamellae extend to or slightly beyond the aperture edge.

The original samples from uMkholombe Mtn collected by H.P. Thomasset remain the only ones known. The specimens from Tugela Estates $\left(28.74^{\circ} \mathrm{S}, 30.17^{\circ} \mathrm{E}\right)$ mentioned by Connolly (1933) were subsequently described as Afrodonta connollyi by Solem (1970).

Costulodonta pluridens gen. et sp. nov.

urn:1sid:zoobank.org:act:46373BEE-D1E5-4F91-BA68-BC4B320DA462

Figs 11, 12A-D, 18O-P

\section{Diagnosis}

Shell small, spire flat or at most slightly raised; protoconch with close-set axial riblets; teleoconch sculpture of close-set, compound axial riblets and microscopic spiral threads; aperture with two rounded, in-running parietal lamellae, the lower one stronger, and a well-developed, in-running, ridge-like basocolumellar denticle; palatal region with four denticles recessed approx. $1 / 8$ whorl behind outer lip. Shell translucent, corneous-brown to pale honey-brown when fresh; diameter up to $1.8 \mathrm{~mm}$.

\section{Etymology}

From the Latin plus: more, and dens: tooth; with reference to the many apertural teeth. 


\section{Material examined}

\section{Holotype}

SOUTH AFRICA • KwaZulu-Natal, Utrecht area, Groenvlei, Guquka Hill (Arrarat Farm); 27.39 $\mathrm{S}$, $30.34^{\circ}$ E; 1700 m a.s.1.; 28 Jan. 1998; D.G. Herbert leg.; montane Podocarpus forest, in leaf-litter; diameter $1.8 \mathrm{~mm}$, height $0.9 \mathrm{~mm}$; NMSA V5920/T4267.

\section{Paratypes}

SOUTH AFRICA • 8 specimens; same collection data as for holotype; NMSA P1019/T4268 • 6 specimens; same collection data as for holotype; montane Podocarpus forest, in moss on tree trunk; NMSA V6287/T4269.

\section{Other material}

SOUTH AFRICA - KwaZulu-Natal • 1 specimen; Utrecht area, Bivane River catchment, Elandsnek, east of Pivaans Waterval Farm; 27.460 ${ }^{\circ}$ S, $30.421^{\circ}$ E; 1850 m a.s.1.; 1 Dec. 1999; D.G. Herbert leg.; small patch of montane Podocarpus forest, in leaf-litter; NMSA V7564 1 specimen; same collection data as for preceding; NMSA V7581.

\section{Description}

Shell small, diameter up to $1.8 \mathrm{~mm}, \mathrm{H} / \mathrm{D}$ ratio \pm 0.50 ; spire flat or at most slightly raised; whorls tightly coiled; last adult whorl very slightly descendant; suture indented, periphery evenly convex. Protoconch comprising apical cap plus approx. $0.75-1.0$ whorl; diameter $\pm 365 \mu \mathrm{m}$; initially smooth, but for the most part sculptured by close-set axial riblets, with indistinct traces of irregular spiral threads. Teleoconch of up to 3.25 whorls; sculptured by distinct, close-set, compound axial riblets with 3-4 finer, uneven,
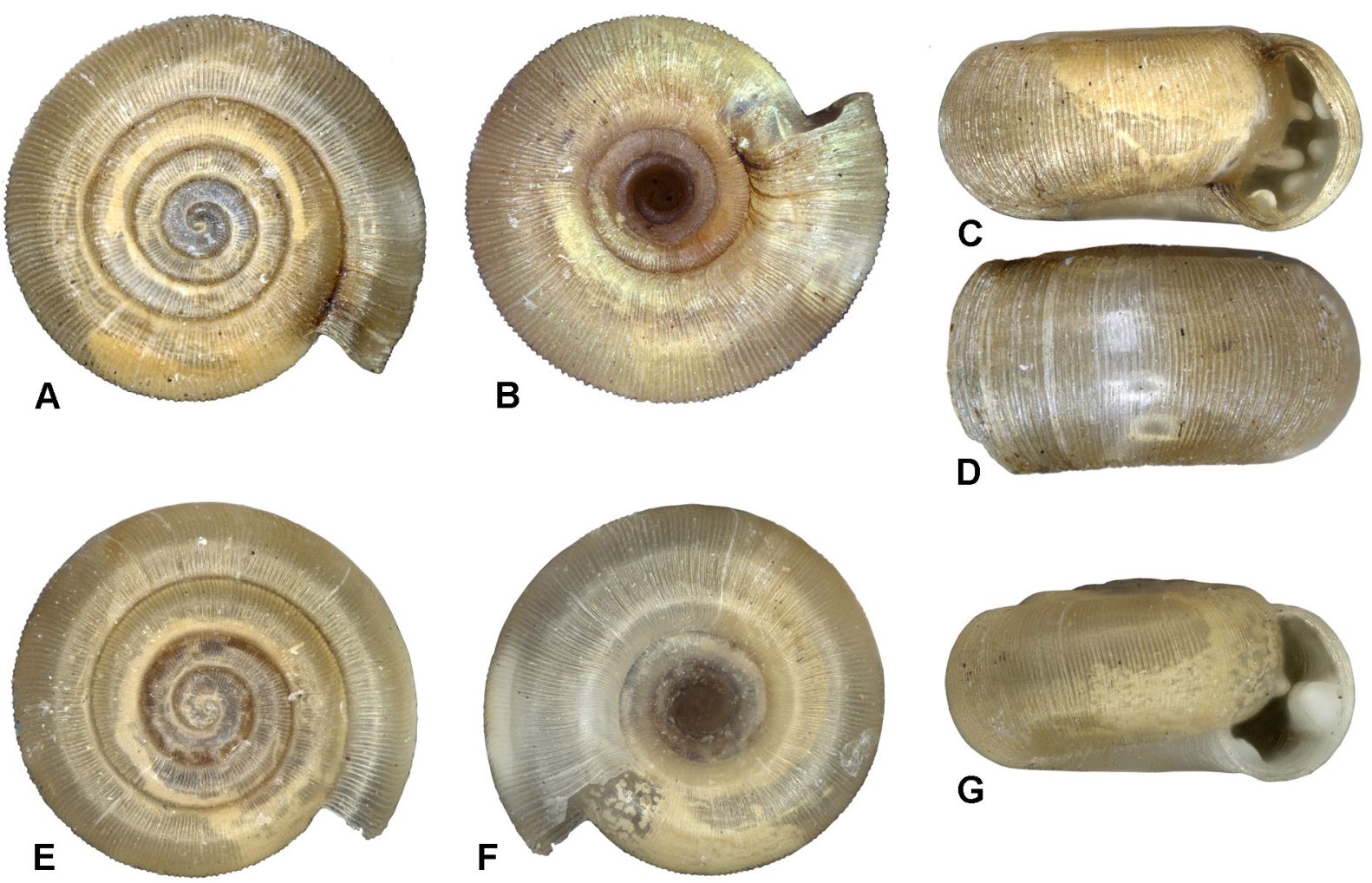

Fig. 12. Shells of Costulodonta gen. nov. species. A-D. C. pluridens gen. et sp. nov., holotype, diameter 1.8 mm (NMSA V5920/T4267). E-G. C. trilamellaris (Melvill \& Ponsonby, 1908) gen. et comb. nov., paralectotype, Dargle, KwaZulu-Natal, diameter 1.45 mm (NMSA 2181/T624). 
intermediary axial threads; intervals between riblets 1-2 times riblet width at whorl periphery; spiral sculpture of microscopic threads more or less throughout, 1-2 stronger threads below suture (visible only under SEM). Umbilicus relatively wide. Aperture lunate, broader basally; parietal region with two rounded, in-running lamellae, the lower one stronger and projecting slightly beyond aperture; baso-columellar region with a well-developed, in-running, ridge-like denticle; palatal region with four denticles recessed approx. $1 / 8$ whorl behind outer lip, shape of denticles somewhat variable, the two below mid-whorl usually elongate, the one just above mid-whorl often more rounded, the fourth is subsutural and very small. Shell translucent, corneous-brown to pale honey-brown when fresh.

\section{Distribution and conservation}

A narrow-range endemic (Fig. 11), known only from the escarpment north of Utrecht, KwaZulu-Natal, at 1700-1850 m; northern afrotemperate forest, in leaf-litter and amongst epiphytic moss on tree trunks. The neighbouring Paardeplats, Pongola Bush and Tafelkop nature reserves need to be surveyed in the hope of finding extant colonies of this species in formally protected areas.

\section{Remarks}

The relatively complex apertural dentition of Costulodonta pluridens gen. et sp. nov. renders it easily separated from other species of Costulodonta gen. nov.

Costulodonta trilamellaris (Melvill \& Ponsonby, 1908) gen. et comb. nov. Figs 11, 12E-G, 18Q-R

Afrodonta trilamellaris Melvill \& Ponsonby, 1908: 134, pl. 7, figs 7, 7a, 7b.

Endodonta [Endodonta (Afrodonta)] trilamellaris - Burnup 1912: 336.

Endodonta (Afrodonta) trilamellaris - Connolly 1912: 128.

Afrodonta trilamellaris - Connolly 1933: text-fig. 1(2); 1939: 252, text-fig. 19(2). — Solem 1970: 357.

- Herbert \& Kilburn 2004: 250, text-fig.

\section{Diagnosis}

Shell very small, spire slightly raised; protoconch with close-set axial riblets (diameter $\pm 415 \mu \mathrm{m}$ ); teleoconch sculpture of compound axial riblets with 2-4 intermediary axial threads; spiral sculpture of close-set, spiral threads, strongest below suture, indistinct elsewhere; parietal region with a low, narrow, in-running ridge; baso-columellar region with a broad, low, in-running ridge; palatal region with a strong, broad, ridge-like denticle just below mid-whorl; umbilicus relatively wide. Shell buff to pale ochre; diameter up to $1.5 \mathrm{~mm}$.

\section{Material examined}

Lectotype (by inference, Connolly 1912: 129)

SOUTH AFRICA • KwaZulu-Natal, Dargle; H.C. Burnup leg.; NHMUK 1908.12.14.42.

\section{Paralectotypes}

SOUTH AFRICA • 2 specimens; same collection data as for lectotype; NHMUK 1937.12.30.2793 to 2794 - 4 specimens; same collection data as for lectotype; NMSA 2175/T624 • 3 specimens; same collection data as for lectotype; NMSA 2181/T624.

\section{Other material}

SOUTH AFRICA - 4 specimens; same collection data as for lectotype; ex Albany Museum; NMSA V3552 4 specimens; same collection data as for lectotype; ex Transvaal Museum; NMSA W462. 


\section{Distribution and conservation}

A narrow-range endemic (Fig. 11), known only from the Dargle area, KwaZulu-Natal, at $\pm 1150 \mathrm{~m}$ a.s.l.; presumably in leaf-litter of southern mistbelt forest. Forested habitats in nature reserves in the Bulwer-Dargle-Karkloof area need to be surveyed in the hope of finding extant colonies of this species in formally protected areas.

\section{Remarks}

Despite the KwaZulu-Natal Midlands being a relatively well-sampled area, the original samples collected by Henry Burnup remain the only ones known of this species.

Genus Iterodonta gen. nov.

urn:lsid:zoobank.org:act:7EB93240-67A5-49A5-A390-FA4A189CD3E4

\section{Type species}

Iterodonta ammonita gen. et sp. nov.

\section{Diagnosis}

Shell small (max. diameter $\pm 1.7 \mathrm{~mm}$ ), shallowly and symmetrically biconcave; umbilicus very wide; whorls tightly coiled; last adult whorl not descendant. Protoconch initially with traces of close-set spiral threads, later portion with spiral threads and close-set axial riblets producing a fine, reticulate sculpture; teleoconch with fine, close-set, axial riblets; riblets compound, composed of several periostracal lamellae; intervals between riblets with fine, uneven, intermediary axial threads and fine spiral threads. Aperture narrowly and symmetrically lunate; parietal dentition absent; palatal region with 1-3 broad, prosocline, axial ridge-like calluses.

\section{Etymology}

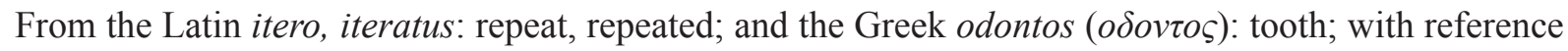
to the episodic deposition and resorption of the palatal dentition. Gender feminine.

\section{Remarks}

Iterodonta gen. nov. is distinctive on account of its reticulate protoconch, relatively strong spiral sculpture on the teleoconch and prosocline palatal calluses.

Iterodonta ammonita gen. et sp. nov. urn:1sid:zoobank.org:act:A33983DE-4995-4FB7-A54D-83F7E4F897D8

Figs 13, 14, 19A-B

\section{Diagnosis}

Shell small, symmetrically biconcave; protoconch initially with traces of close-set spiral threads, later portion with spiral threads and close-set axial riblets producing a fine, reticulate sculpture; teleoconch sculpture of close-set, compound axial riblets with finer, uneven intermediary axial threads; aperture lacking parietal and columellar dentition; palatal region with 1-3 broad, prosocline, axial ridge-like calluses set back from lip, visible through translucent shell; umbilicus very wide and shallow. Shell translucent, straw-brown to pale honey-brown; diameter up to $1.68 \mathrm{~mm}$.

\section{Etymology}

From ammonite (Ammonoidea); with reference to the symmetrically biconcave shell. 


\section{Material examined}

\section{Holotype}

SOUTH AFRICA • W. Cape, Riviersonderendberge, Oubos (Oudebosch); $34.07702^{\circ} \mathrm{S}, 19.82884^{\circ} \mathrm{E}$; $440 \mathrm{~m}$ a.s.1.; 11 Oct. 2007; D.G. Herbert and L.S. Davis leg.; afrotemperate forest, in leaf-litter and under logs; diameter $1.45 \mathrm{~mm}$, height $0.70 \mathrm{~mm}$; NMSA W5826/T4258.

\section{Paratypes}

SOUTH AFRICA - W. Cape 3 specimens; same collection data as for holotype; NMSA P1017/T4259 - 1 specimen; Grootvadersbosch Nat. Res.; $33.98994^{\circ}$ S, $20.81658^{\circ}$ E; 345 m a.s.1.; 13 Oct. 2007; D.G. Herbert and L.S. Davis leg.; afrotemperate forest, in leaf-litter and under logs; NMSA W5899/ T4256.

\section{Description}

Shell small, diameter up to $1.68 \mathrm{~mm}, \mathrm{H} / \mathrm{D}$ ratio \pm 0.48 ; symmetrically biconcave, whorls tightly coiled, but not conspicuously deep; spire sunken, but not deeply so; last adult whorl not descendant; suture strongly indented and apical and basal portions of whorls strongly convex, less so at mid-whorl; periphery evenly convex. Protoconch comprising apical cap plus approx. 1.25 whorls; diameter $\pm 330 \mu \mathrm{m}$; initially with traces of close-set spiral threads, later portion with spiral threads and close-set axial riblets producing a fine, reticulate sculpture. Teleoconch of up to 3.5 whorls; sculptured by distinct, close-set compound, orthocline axial riblets with finer, uneven intermediary axial threads; intervals between riblets approx. twice riblet width at whorl periphery; spiral sculpture relatively distinct, comprising microscopic spiral threads, most obvious in intervals between riblets; threads coarsest below suture and in umbilicus, but present throughout. Umbilicus very wide and relatively shallow (Fig. 13B). Aperture narrow, more or less symmetrically lunate, with apical limit rounded; parietal and columellar dentition lacking; palatal region with 1-3 broad, prosocline, axial, ridge-like calluses set back $1 / 8-1 / 2$ whorl from lip (position variable), visible through translucent shell (Fig. 13D); calluses slightly curved, one usually well developed, the others in the process of resorption or deposition. Shell translucent, straw-brown to pale honey-brown.

\section{Distribution and conservation}

A narrow-range endemic (Fig. 14), known only from the south-facing slopes of the Langeberge and Riviersonderendberge, W. Cape, at 300-450 m a.s.l.; in leaf-litter of southern afrotemperate forest. Grootvadersbosch Nature Reserve is a formally protected area and the indigenous forest of the Langeberge and Riviersonderendberge are generally well managed, with additional formally protected areas that should be surveyed in the hope of finding additional extant colonies of this species.
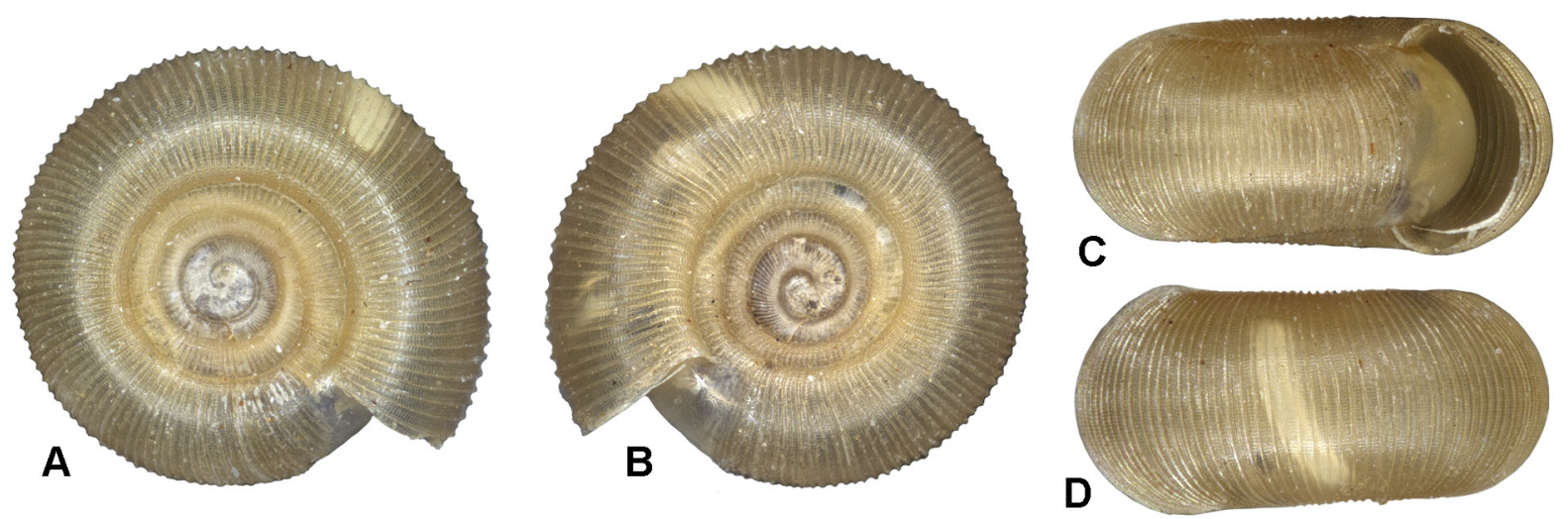

Fig. 13. Iterodonta ammonita gen. et sp. nov., holotype, diameter 1.45 mm (NMSA W5826/T4258). 


\section{Remarks}

Iterodonta ammonita gen. et sp. nov. is highly distinctive amongst the southern African charopid fauna. The only other African species with similar palatal dentition is Endodonta kempi Connolly, 1925 recorded from Kenya, Malawi and Zambia (Bruggen 1988, 2007), but in that species the spire is not sunken, the umbilicus is narrower and the protoconch lacks distinctive sculpture. Solem (1970) referred the latter to Afrodonta, but this seems improbable and its true relationships require further investigation.

\section{Genus Phialodonta gen. nov. urn:1sid:zoobank.org:act:39C2A680-FD1C-486C-AC3E-3F23EED1CD33}

\section{Type species}

Phialodonta aviana gen. et sp. nov.

\section{Diagnosis}

Shell very small to relatively large (adult diameter $\pm 1.3-2.0 \mathrm{~mm}$ ), spire slightly sunken to slightly elevated; umbilicus moderate to very wide; whorls strongly rounded, periphery at mid-whorl. Protoconch smooth or with low, weakly undulant axial sculpture. Teleoconch with close-set axial riblets; riblets compound, composed of several periostracal lamellae; intervals between riblets with several finer intermediary axial threads; spiral sculpture weak, at most comprising extremely fine, close-set spiral threads. Aperture lunate to broadly lunate, variously furnished with parietal and palatal dentition in the form of denticles and/or in-running lamellae/ridges.

\section{Etymology}

From the Latin phiala: a saucer or bowl, and donta: a contraction of Afrodonta; with reference to the wide, shallow umbilicus. Gender feminine.

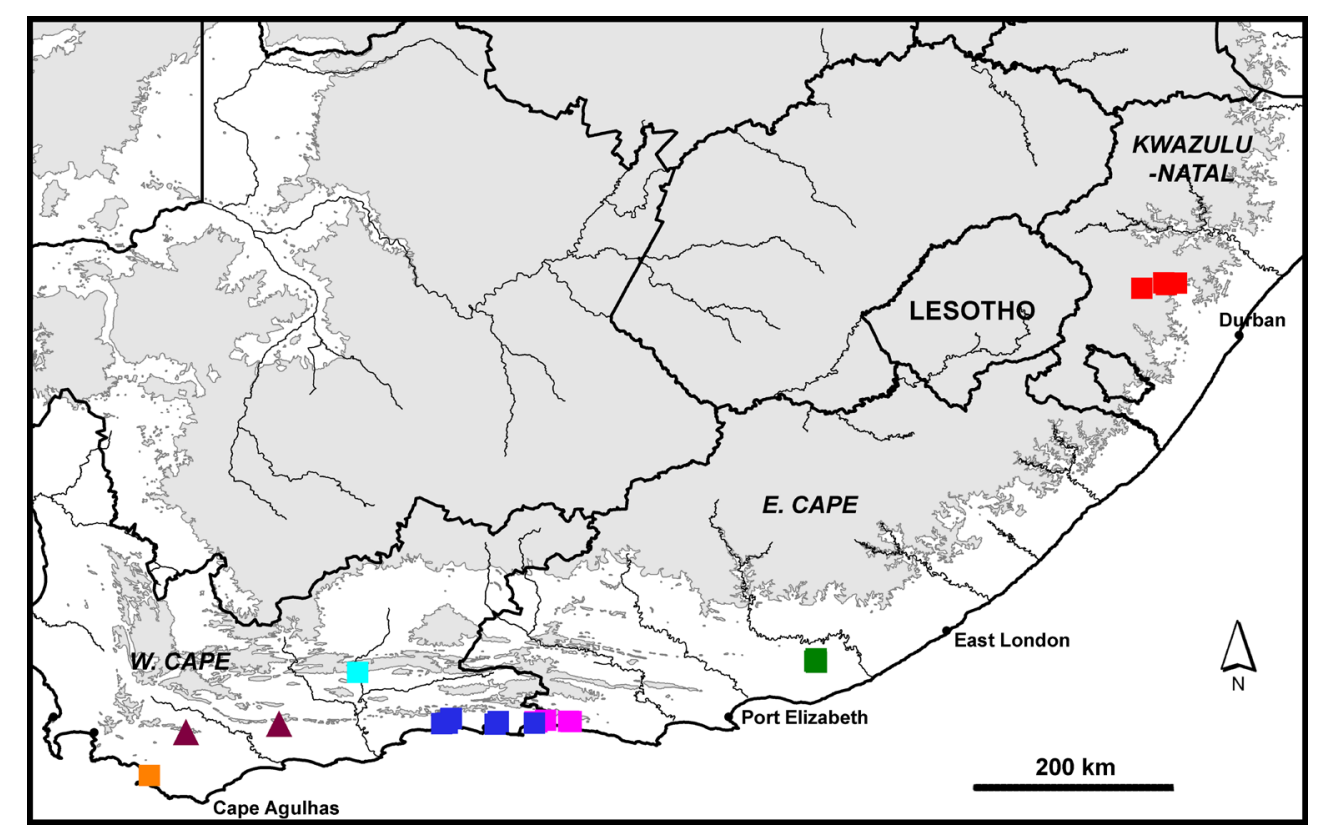

Fig. 14. Distribution of Iterodonta gen. nov. and Phialodonta gen. nov. species. Iterodonta ammonita gen. et sp. nov. (brown triangles), Phialodonta agulhasae gen. et sp. nov. (orange square), P. atromontana gen. et sp. nov. (turquoise square), P. aviana gen. et sp. nov. (royal blue squares), P. introtuberculata (Connolly, 1933) gen. et comb. nov. (red squares), P. perfida (Burnup, 1912) gen. et comb. nov. (green square), P. rivalalea gen. et sp. nov. (pink squares). Contour at $1000 \mathrm{~m}$. 


\section{Remarks}

Phialodonta gen. nov. is proposed for a group of species which share a smooth or weakly sculptured protoconch and a relatively coarse teleoconch sculpture of compound axial riblets with multiple fine intermediary axial threads. The genus ranges widely, from the Agulhas region, W. Cape to the KwaZuluNatal Midlands. In Costulodonta gen. nov. the protoconch has distinct radial riblets and the teleoconch sculpture is generally somewhat finer. Members of Afrodonta have a somewhat similar protoconch, but they possess a silky teleoconch sculpture comprised of simple axial riblets of alternating strength.

\section{Key to species of Phialodonta gen. nov.}

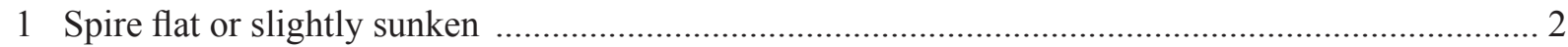

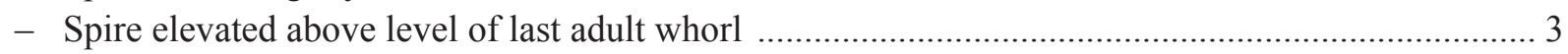

2 Palatal region with 1-3 axially aligned pairs of rounded denticles situated approx. 0.25 whorl apart; KwaZulu-Natal ................................................................ P. introtuberculata gen. et comb. nov.

- Palatal region with three in-running ridge-like denticles; W. Cape ........P. agulhasae gen. et sp. nov.

3 Adult shell with no parietal dentition visible through aperture ..................................................... 4

- Adult shell with parietal dentition visible through aperture .......................................................... 5

4 Palatal region with two long, in-running lamellae (visible only by transparency)

- Palatal region with three in-running lamellae (visible only by transparency)

P. perfida gen. et comb. nov.

P. aviana gen. et sp. nov.

5 Palatal region with 3-4 recessed denticles, plus a narrow, in-running baso-columellar ridge

P. rivalalea gen. et sp. nov.

- Palatal region with two pairs of close-set, spirally aligned denticles, no dentition in baso-columellar region

P. atromontana gen. et sp. nov.

Phialodonta agulhasae gen. et sp. nov.

urn:1sid:zoobank.org:act:C5A5E2C0-CEF1-41DC-B8B2-7095C029E70B

Figs $14,15 \mathrm{~A}-\mathrm{D}$

\section{Diagnosis}

Shell very small, planorboid, spire slightly sunken; protoconch lacking axial sculpture; teleoconch sculpture of close-set axial riblets with extremely fine, close-set spiral threads in their intervals; aperture lacking parietal and baso-columellar dentition, palatal region with three recessed, in-running, ridge-like denticles; umbilicus wide. Shell corneous-brown; diameter up to $1.3 \mathrm{~mm}$.

\section{Etymology}

Named after the Agulhas region.

\section{Material examined}

\section{Holotype}

SOUTH AFRICA • W. Cape, Gansbaai area, Grootbos Private Nat. Res.; $34.54135^{\circ}$ S, $19.43871^{\circ}$ E; 8 Oct. 2007; D.G. Herbert and L.S. Davis leg.; station 07-044, afrotemperate forest, in leaf-litter and under logs; diameter $1.3 \mathrm{~mm}$, height $0.61 \mathrm{~mm}$; NMSA W7816/T4257. 


\section{Description}

Shell very small, diameter up to $1.3 \mathrm{~mm}, \mathrm{H} / \mathrm{D}$ ratio 0.47 ; planorboid, spire slightly sunken; whorls tightly coiled, not conspicuously deep; last adult whorl not descendant; suture shallowly indented, periphery evenly convex. Protoconch comprising apical cap plus approx. 1.0 whorl; diameter $\pm 320 \mu \mathrm{m}$; microscopically shagreened, lacking axial sculpture. Teleoconch of \pm 3.0 whorls; sculptured by distinct,
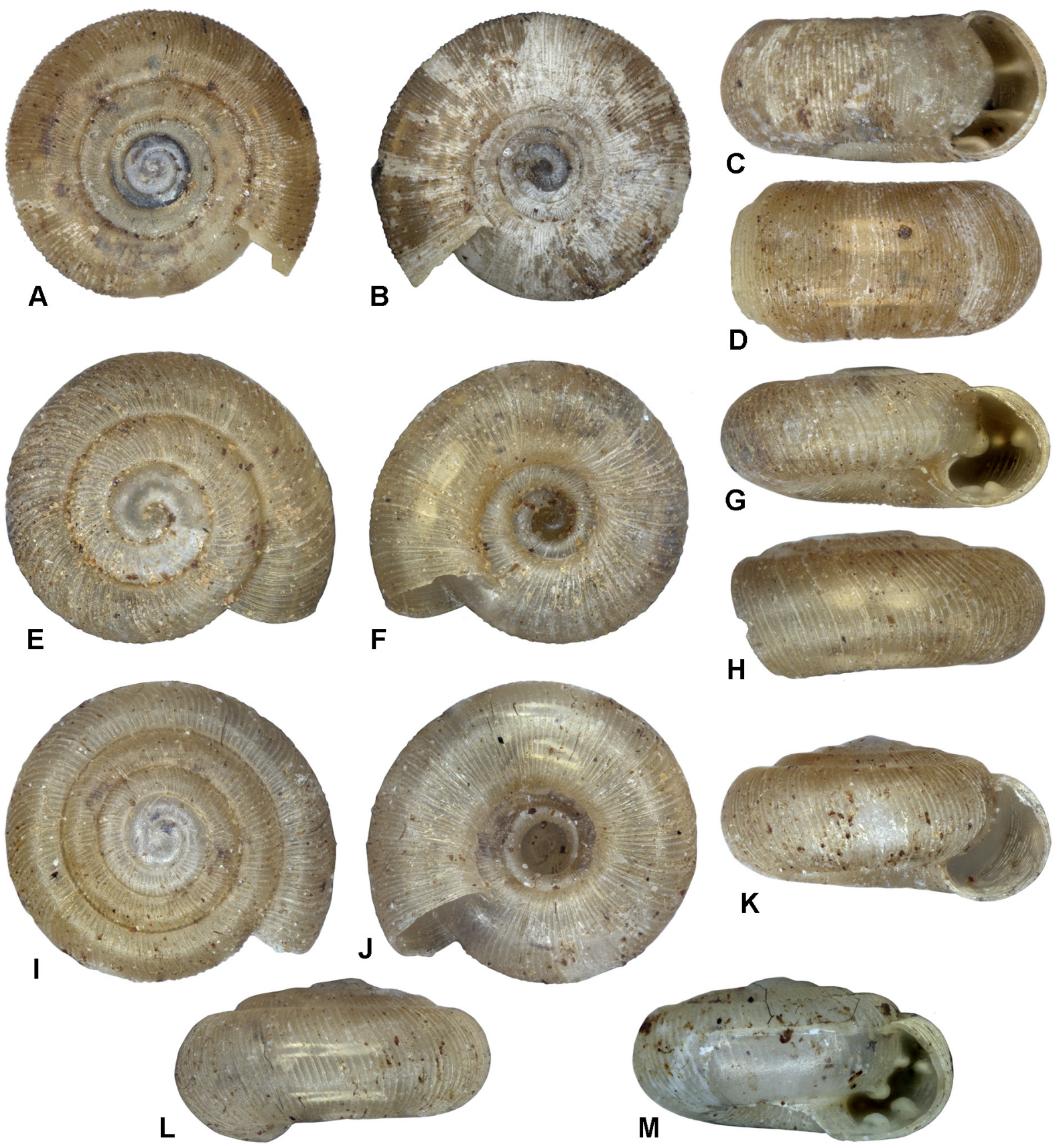

Fig. 15. Shells of Phialodonta gen. nov. species. A-D. P. agulhasae gen. et sp. nov., holotype, diameter $1.30 \mathrm{~mm}$ (NMSA W7816/T4257). E-H. P. atromontana gen. et sp. nov., holotype, diameter $1.40 \mathrm{~mm}$ (NMSA W9580/T4254). I-L. P. aviana gen. et sp. nov., holotype, diameter $1.40 \mathrm{~mm}$ (NMSA W624/ T4246). M. P. aviana gen. et sp. nov., specimen with palatal region broken back to reveal apertural dentition, paratype, Touwsrivier, Wilderness, W. Cape, diameter 1.32 mm (NMSA W3511/T4248). 
close-set, axial riblets, intervals between riblets more or less equal to width of riblets at whorl periphery; spiral sculpture of extremely fine, close-set threads in riblet intervals. Umbilicus wide. Aperture lunate, relatively narrow, apical and basal limits rounded; parietal and baso-columellar regions lacking dentition; palatal region with three recessed, in-running, ridge-like denticles, one just above mid-whorl, one just below mid-whorl and one basal. Shell corneous-brown.

\section{Distribution and conservation}

A narrow-range endemic (Fig. 14), known only from the type locality; in leaf-litter of southern afrotemperate forest. The type locality lies in a well-managed private nature reserve, but additional Agulhas Plain localities that retain patches of southern afrotemperate forest need to be surveyed in the hope of finding additional extant colonies of this species.

\section{Remarks}

The holotype is the only specimen available and though it is not a fresh shell, it is sufficiently distinct to permit its description as a new species. I have refrained from examining it under SEM due to its fragility and thus finer details of its sculpture are not available. On account of its smooth protoconch, relatively distinct axial riblets and wide umbilicus, I refer it to Phialodonta gen. nov. In its planorboid shape it resembles $P$. introtuberculata gen. et comb. nov., but that species has a proportionately narrower shell (mean H/D ratio 0.424 - Solem 1970) and very different apertural dentition.

Phialodonta atromontana gen. et sp. nov. urn:1sid:zoobank.org:act:4A34E0A1-99C9-4892-83DC-080F239C0921

Figs $14,15 \mathrm{E}-\mathrm{H}, 19 \mathrm{C}-\mathrm{D}$

\section{Diagnosis}

Shell very small, spire slightly raised; protoconch lacking axial sculpture; teleoconch sculpture of curved, close-set, compound, axial riblets, with 4-5 finer, intermediary axial threads; spiral sculpture of extremely fine, close-set threads; aperture with a low, rounded, in-running parietal ridge, lacking basocolumellar dentition; palatal region with two pairs of close-set, spirally aligned denticles, one pair close to mid-whorl, the other basal; umbilicus wide. Shell pale corneous-brown to honey-brown; diameter up to $1.4 \mathrm{~mm}$.

\section{Etymology}

From the Latin ater: black, and mons: a mountain; with reference to the Groot Swartberg range.

\section{Material examined}

Holotype

SOUTH AFRICA • W. Cape, Calitzdorp area, Matjiesvlei; $33.44525^{\circ} \mathrm{S}, 21.65388^{\circ} \mathrm{E}$; $360 \mathrm{~m}$ a.s.l.; 4 Nov. 2013; D.G. Herbert, L.S. Davis, M. and K. Cole leg.; rocky hillside with succulents and aloes, in leaf-litter; diameter $1.4 \mathrm{~mm}$, height $0.61 \mathrm{~mm}$; NMSA W9580/T4254.

\section{Paratypes}

SOUTH AFRICA • 7 specimens; same collection data as for holotype; NMSA P1016/T4255.

\section{Description}

Shell very small, diameter up to $1.4 \mathrm{~mm}, \mathrm{H} / \mathrm{D}$ ratio \pm 0.43 ; spire slightly raised; whorls tightly coiled, relatively narrow; last adult whorl descending slightly below penultimate whorl; suture narrowly indented, periphery evenly convex. Protoconch comprising apical cap plus approx. 0.67 whorl; diameter $\pm 410 \mu \mathrm{m}$; smooth to microscopically shagreened, lacking axial sculpture. Teleoconch of up to 2.25 
whorls; sculptured by distinct, curved, close-set, compound axial riblets, with 4-5 finer, uneven, intermediary axial threads; intervals between riblets approx. twice riblet width at whorl periphery; spiral sculpture of extremely fine, close-set threads more or less throughout. Umbilicus wide. Aperture broadly lunate to almost D-shaped; parietal region with a low, rounded, in-running ridge just below mid-whorl; baso-columellar region lacking dentition; palatal region with two pairs of close-set, spirally aligned denticles, one pair close to mid-whorl, the other basal. Shell pale corneous-brown to honey-brown, usually encrusted with soil particles.

\section{Distribution and conservation}

A narrow-range endemic (Fig. 14), known only from the southern edge of the Groot Swartberge in the region of Calitzdorp, at $360 \mathrm{~m}$ a.s.l.; in accumulations of leaf-litter in sheltered microhabitats within Gamka Thicket. The type locality lies close to the protected Klein Swartberg Mountain Catchment Area and there are also several private and provincial nature reserves in the vicinity. Further sites in these areas need to be surveyed in the hope of finding additional extant colonies of the species.

\section{Remarks}

Conchologically closest to Phialodonta aviana gen. et sp. nov. and $P$. rivalalea gen. et sp. nov., but differs in the form of the palatal dentition. In specimens at intermediate growth stages the palatal denticles may be single rather than paired, or even totally absent.

Phialodonta aviana gen. et sp. nov. urn:lsid:zoobank.org:act:82C94EDA-3DF6-444B-8490-0ED744917CD0

Figs 14, 15I-M, 19E-F

\section{Diagnosis}

Shell small, spire raised; protoconch lacking axial sculpture; teleoconch sculpture of distinct, close-set, compound axial riblets, intervals with finer intermediaries and extremely fine, close-set spiral threads; aperture lacking visible dentition; all dentition deeply recessed, comprising two low, rounded, inrunning parietal ridges and three in-running, ridge-like palatal denticles, visible by transparency; basocolumellar dentition lacking; umbilicus wide. Shell pale corneous-brown to honey-brown when fresh; diameter up to $1.55 \mathrm{~mm}$.

\section{Etymology}

From the Latin avium: a desert, wilderness; with reference to the Wilderness region, W. Cape.

\section{Material examined}

\section{Holotype}

SOUTH AFRICA • W. Cape, Wilderness area, Woodville 'Big Tree'; $33.933^{\circ} \mathrm{S}, 22.650^{\circ} \mathrm{E} ; 265 \mathrm{~m}$ a.s.1.; 1 Oct. 2002; J.P. Marais leg.; indigenous forest, in leaf-litter; diameter $1.4 \mathrm{~mm}$, height $0.71 \mathrm{~mm}$; NMSA W624/T4246.

\section{Paratypes}

SOUTH AFRICA - W. Cape -8 specimens; Wilderness Nat. Park, Kaaimansrivier; $33.98921^{\circ} \mathrm{S}$, $22.55130^{\circ}$ E; $25 \mathrm{~m}$ a.s.1.; 11 Mar. 2005; A. Moussalli and D. Stuart-Fox leg.; indigenous forest, in leaf-litter; NMSA W3524/T4247 • 6 specimens; Wilderness area, Touwsrivier valley; $33.98348^{\circ} \mathrm{S}$, $22.60948^{\circ}$ E; 30 m a.s.1.; 13 Mar. 2005; A. Moussalli and D. Stuart-Fox leg.; indigenous forest, in leaf-litter; NMSA W3511/T4248 • 11 specimens; Knysna Forest, Diepwalle region, Ysterhout site; $33.967^{\circ} \mathrm{S}, 23.150^{\circ} \mathrm{E}$; $380 \mathrm{~m}$ a.s.1.; 28 Apr. 1997; D.G. Herbert leg.; indigenous forest, sorted from leaflitter; NMSA V4708/T4245. 
Other material

SOUTH AFRICA - W. Cape - 1 specimen; Wilderness Nat. Park, Big Tree area; $33.93661^{\circ} \mathrm{S}$, 22.64421 ${ }^{\circ}$ E; 244 m a.s.1.; 6 Mar. 2005; A. Moussalli and D. Stuart-Fox leg.; indigenous forest, in leaflitter; NMSA W2975 • 3 specimens; same collection data as for holotype; NMSA P1011 23 specimens; Knysna, start of Prince Alfred's Pass, just inland from town; $33.996^{\circ} \mathrm{S}, 23.117^{\circ} \mathrm{E} ; 360 \mathrm{~m}$ a.s.1.; 28 Apr. 1997; D.G. Herbert leg.; indigenous forest; NMSA V4983 • 13 specimens; Nature's Valley, Salt River area; $33.983^{\circ} \mathrm{S}, 23.533^{\circ} \mathrm{E} ; \pm 50 \mathrm{~m}$ a.s.1.; 19 Sep 2003; D.G. Herbert leg.; indigenous forest; NMSA W1188.

\section{Description}

Shell small, diameter up to $1.55 \mathrm{~mm}, \mathrm{H} / \mathrm{D}$ ratio \pm 0.5 ; spire raised, whorls tightly coiled; last adult whorl slightly descendant; suture narrowly indented, somewhat sunken; periphery evenly convex. Protoconch comprising apical cap plus approx. 1.0 whorl; diameter $\pm 360 \mu \mathrm{m}$; smooth to microscopically shagreened, lacking axial sculpture. Teleoconch of up to 3.25 whorls; sculptured by distinct, close-set, compound axial riblets, with \pm 5 finer, intermediary axial threads; intervals between riblets approx. twice riblet width at whorl periphery; spiral sculpture of extremely fine, close-set threads more or less throughout. Umbilicus wide. Aperture broadly lunate, lacking any visible dentition; all dentition deeply recessed; parietal region with two low, rounded, in-running ridges, lower one stronger; baso-columellar region lacking dentition; palatal region with three in-running, ridge-like denticles visible by transparency, one just above mid-whorl, one basal and the third between these. Shell pale corneous-brown to honey-brown when fresh.

\section{Distribution and conservation}

Anarrow-range endemic (Fig. 14), known only from the coastal hinterland in the Outeniqua-Tsitsikamma region, in the environs of Wilderness, Knysna and Nature's Valley, from the coast to $380 \mathrm{~m}$ a.s.1.; in leaflitter of southern afrotemperate forest. The forests in this region fall within the Garden Route National Park and are thus afforded a high degree of protection.

\section{Remarks}

As in Phialodonta perfida gen. et comb. nov., the internal dentition of $P$. aviana gen. et sp. nov. is recessed to such an extent that it is not visible in undamaged apertural view. The palatal denticles, however, are visible externally by transparency, but the parietal lamellae can only be seen if the palatal region is broken back. Phialodonta perfida gen. et comb. nov. differs from the present species in having a single, inwardly broadening, parietal lamella and only two palatal ridges. It also attains a larger size. P. perfida gen. et comb. nov. is only recorded from the Grahamstown area, and the known ranges of the two species are separated by a distance of over $300 \mathrm{~km}$.

The easternmost population of $P$. aviana gen. et sp. nov. in the Nature's Valley area is unusual in that some individuals have four palatal denticles instead of three, the upper two of which are distinctly longer than the lower two. In other respects, however, they are identical to typical specimens from the KnysnaWilderness area. This population is also noteworthy in that it shows that $P$. aviana gen. et sp. nov. and $P$. rivalalea gen. et sp. nov. are parapatric, perhaps even sympatric, in the vicinity of Nature's Valley. Additional survey work is needed to further explore this issue. The differences between the two are discussed in the remarks pertaining to $P$. rivalalea gen. et sp. nov.

Phialodonta introtuberculata (Connolly, 1933) gen. et comb. nov.

Figs 14, 16A-D, 19G-H

Afrodonta introtuberculata Connolly, 1933: 147, text-fig. 1(9), pl. 7, figs 5-8.

Afrodonta introtuberculata - Connolly 1939: 255, text-fig. 19(9). — Solem 1970: 361. — Herbert \& Kilburn 2004: 247, text-fig. 


\section{Diagnosis}

Shell relatively large, narrowly planorboid, spire slightly sunken; protoconch initially smooth, becoming microscopically shagreened and finally with low axial undulations (diameter $\pm 350 \mu \mathrm{m}$ ); teleoconch sculptured by relatively strong, close-set, compound axial riblets, intervals between riblets with 3-4 microscopic axial threads; spiral sculpture scarcely evident even in umbilicus; parietal and basocolumellar dentition lacking; palatal region with 1-3 axially aligned pairs of denticles set back $1 / 8$ to $1 / 2$ whorl behind outer lip, outermost pair usually visible through aperture, the others apparent only through translucent shell; lower denticle well below periphery, upper one slightly above periphery; number and position of denticle pairs somewhat variable and related to degree of development; umbilicus shallow and very wide. Shell translucent, honey-brown when fresh; diameter up to $2.0 \mathrm{~mm}$.
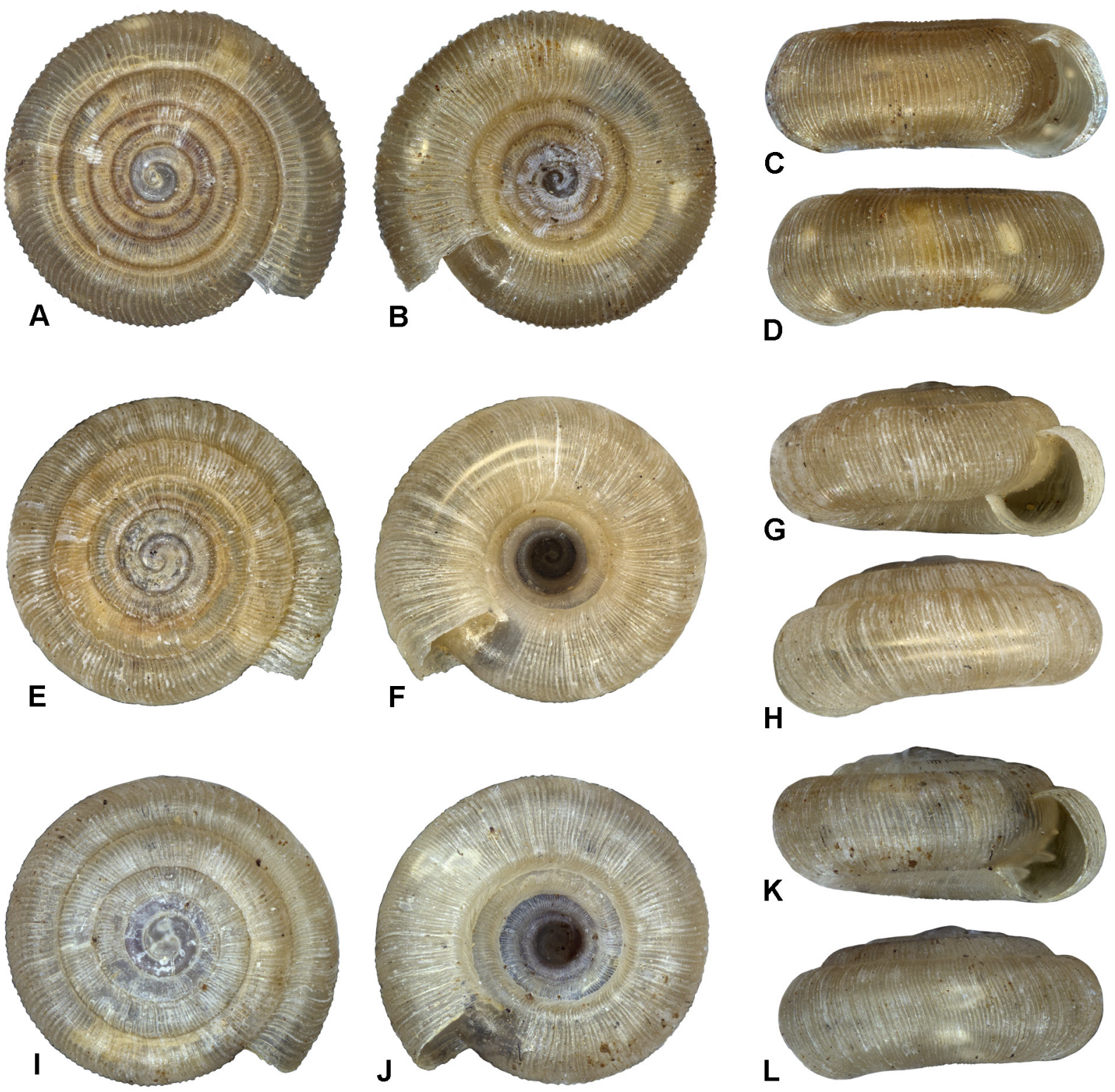

Fig. 16. Shells of Phialodonta gen. nov. species. A-D. P. introtuberculata (Connolly, 1933) gen. et comb. nov., Karkloof, KwaZulu-Natal, diameter 1.87 mm (NMSA W2438). E-H. P. perfida (Burnup, 1912) gen. et comb. nov., paratype, diameter $1.84 \mathrm{~mm}$ (NMSA 2602/T617). I-L. P. rivalalea gen. et sp. nov., holotype, diameter $1.70 \mathrm{~mm}$ (NMSA W3114 /T4251). 


\section{Material examined}

Holotype

SOUTH AFRICA • KwaZulu-Natal, Nottingham Road; prior to 1928; A.J. Taynton leg.; NHMUK 1931.6.4.1.

\section{Paratypes}

SOUTH AFRICA • 3 specimens; same collection data as for holotype; NHMUK 1937.12.30.2759 to 2761.

\section{Other material}

SOUTH AFRICA - KwaZulu-Natal • 4 specimens; Karkloof, Mbona Private Nat. Res., Holbeck; 29.3009 ${ }^{\circ}$ S, $30.3615^{\circ}$ E; 1300 m a.s.1.; 22 Jun. 2002; D.G. Herbert leg.; mistbelt Podocarpus forest, in leaf-litter; NMSA W216 • 1 specimen; Karkloof, Mbona Private Nat. Res., Holbeck area; $29.30119^{\circ}$ S, $30.35899^{\circ}$ E; 1400 m a.s.1.; 25 Apr. 2004; D.G. Herbert leg.; mistbelt Podocarpus forest, in leaf-litter; NMSA W1810 • 3 specimens; Karkloof, Mbona Private Nat. Res., Holbeck; $29.30339^{\circ} \mathrm{S}, 30.36525^{\circ} \mathrm{E}$; 1330 m a.s.1.; 24 Oct. 2004; D.G. Herbert leg.; mistbelt Podocarpus forest, in leaf-litter; NMSA W2438 - 1 specimen; Karkloof, Leopard's Bush; $29.3183^{\circ} \mathrm{S}, 30.2580^{\circ}$ E; ca 1350 m a.s.1.; 23 Nov. 1998; D.G. Herbert, M. Seddon and P. Tattersfield leg.; mistbelt Podocarpus forest, in leaf-litter; NMSA V8417 • 3 specimens; Karkloof Nat. Res.; $29.30^{\circ}$ S, 30.23 E; 1 Dec. 2003; A. Moussalli and D. StuartFox leg.; mistbelt Podocarpus forest, in leaf-litter; NMSA W3789 7 specimens; Nottingham Road; $29.358^{\circ} \mathrm{S}, 29.995^{\circ} \mathrm{E}$; ca $1500 \mathrm{~m}$ a.s.1.; pre-1928; A.J. Taynton leg.; NMSA A9191 46 specimens; same collection data as for preceding; NMSA A9192 - 3 specimens; same collection data as for preceding; NMSA A9193 • 6 specimens; same collection data as for preceding; NMSA A9221.

\section{Distribution and conservation}

A narrow-range endemic (Fig. 14), known only from the Karkloof-Nottingham Road area in the KwaZulu-Natal Midlands, at 1300-1500 m a.s.l.; in leaf-litter of southern mistbelt forest. Judging by the numbers of specimens in the original samples collected by A.J. Taynton in the Nottingham Road area (pre-1928), the species may be locally common or abundant. There are a number of provincial and private nature reserves in this area in which the species has been collected in recent years.

\section{Remarks}

Phialodonta introtuberculata gen. et comb. nov. is distinguished from other species in the genus by its much flatter shell and paired palatal dentition. Afrodonta geminodonta sp. nov. has similar sets of paired palatal denticles, but its spire is raised, the axial sculpture much finer and the umbilicus much narrower.

Specimens somewhat resembling $P$. introtuberculata gen. et comb. nov. have been found in the Creighton area (Hlabeni Forest, $29.975^{\circ} \mathrm{S}, 29.742^{\circ} \mathrm{E}$, NMSA V5219). However, although they have similar palatal dentition, their axial sculpture is noticeably finer, the umbilicus not as wide and they are milky-white in colour.

Fig. 17. (next page) Afrodonta species, detail of protoconch morphology and teleoconch microsculpture. A-B. Af. bilamellaris (NMSA V7333). C-D. Af. connollyi (NMSA V7094). E-F. Af. farquhari (NMSA V7908). G-H. Af. geminodonta sp. nov., paratype (NMSA P1010/T4244). I-J. Af. inhluzaniensis inhluzaniensis (NMSA V7240). K-L. Af. inhluzaniensis leptolamellaris subsp. nov., paratype (NMSA P1008/T4236). M-N. Af. mystica sp. nov., paratype (NMSA P1009/T4238). O-P. Af. novemlamellaris (NMSA W6254). Q-R. Af. pentodon sp. nov., paratype (NMSA V8275/T4240). Scale bars for protoconchs $=100 \mu \mathrm{m}$; scale bars for microsculpture $=50 \mu \mathrm{m}$. 
HERBERT D.G., Dentate charopid snails of southern Africa
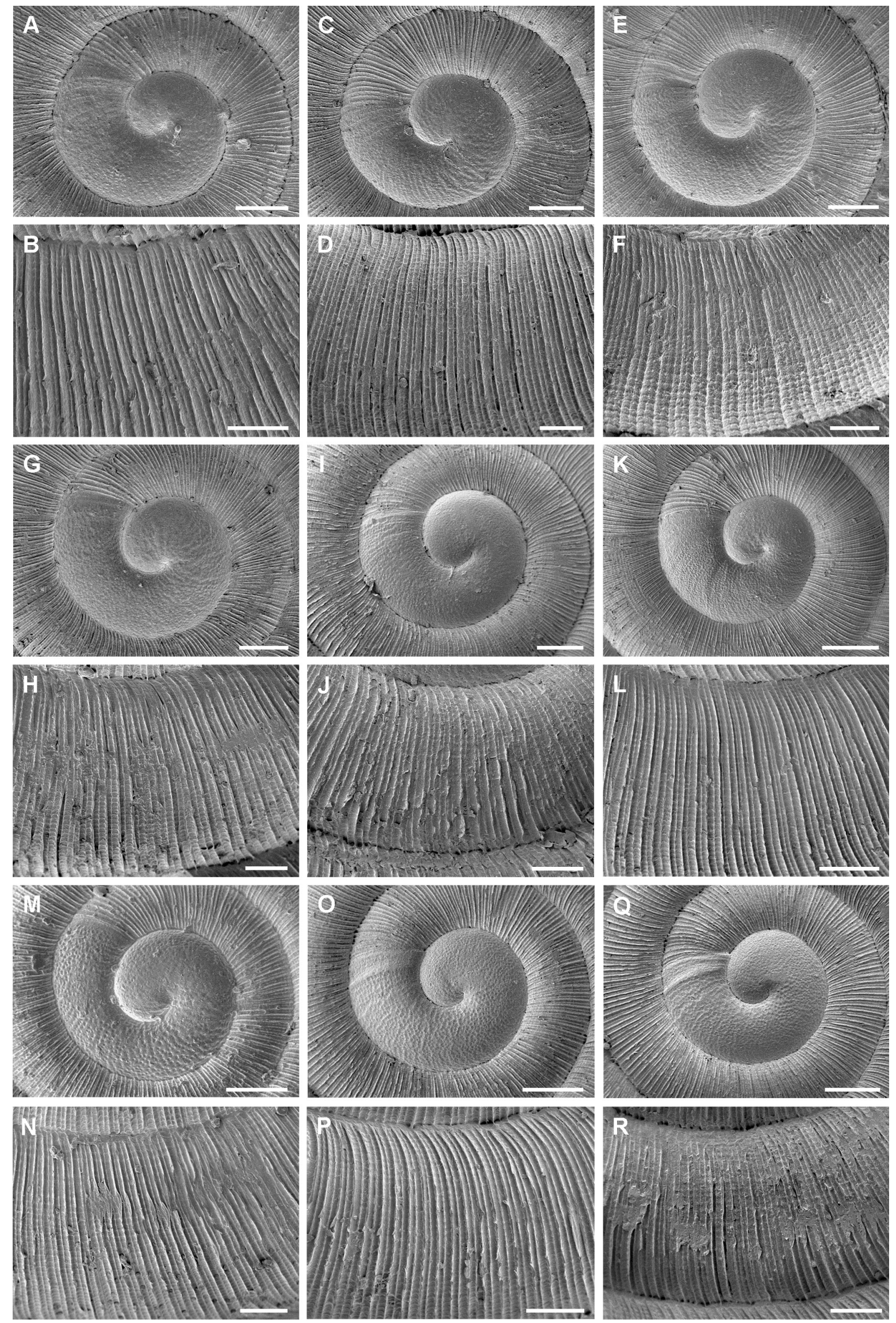
Phialodonta perfida (Burnup, 1912) gen. et comb. nov.

Figs 14, 16E-H, 19I-J

Trachycystis rotula Melvill \& Ponsonby, 1907: 99, pl. 6, figs 12, 12a.

Endodonta [Endodonta (Afrodonta)] perfida Burnup, 1912:337, pl. 24, figs 1-6. Nom. nov. for Endodonta rotula (Melvill \& Ponsonby, 1907), non Hombron \& Jacquinot, 1852.

Endodonta (Afrodonta) perfida - Connolly 1912: 128.

Afrodonta perfida - Connolly 1939: 255.

Afrodonta rotula - Solem 1970: 356.

\section{Diagnosis}

Shell relatively large, spire distinctly raised, last adult whorl descendant, whorls slightly flat-sided; protoconch evidently smooth (somewhat worn in the material available), diameter $\pm 425 \mu \mathrm{m}$; teleoconch sculptured by relatively strong, close-set, compound axial riblets, intervals between riblets with 3-4 microscopic axial threads; spiral sculpture of faint microscopic threads, but for the most part scarcely evident, even in umbilicus; aperture broadly lunate, with no visible dentition; parietal region with a single deeply recessed, low lamella, broadening inwardly; baso-columellar dentition lacking; palatal region with two recessed, relatively long, in-running ridge-like denticles, one at periphery the other in middle of base, visible by transparency; umbilicus wide. Shell translucent, corneous-brown when fresh; diameter up to $1.95 \mathrm{~mm}$.

\section{Material examined}

Syntypes (of Trachycystis rotula Melvill \& Ponsonby, 1907)

SOUTH AFRICA • 2 specimens (initially registered in error as a single specimen 1907.7.20.45); E. Cape, Grahamstown, Fernkloof; J. Farquhar leg.; following ICZN Art 72.7, these are also syntypes of Endodonta (Afrodonta) perfida Burnup, 1912; NHMUK 1907.7.20.44 to 45.

Additional material (used to re-describe and figure taxon under new name Endodonta (Afrodonta) perfida Burnup, 1912)

SOUTH AFRICA - E. Cape - 1 specimen; Grahamstown, Fernkloof; J. Farquhar leg.; NHMUK 1912.3.25 • 3 specimens; same collection data as for preceding; NHMUK 1937.12.30.2790 to $2792 \cdot 2$ specimens; same collection data as for preceding; NMSA A9618/T617 • 3 specimens; Grahamstown; NMSA 2602/T617 • 2 specimens; same collection data as for preceding; NMSA 2603/T617 • 1 specimen; same collection data as for preceding; NMSA A9617/T617.

\section{Other material}

SOUTH AFRICA - E. Cape • 3 specimens; Grahamstown, Fernkloof; NMSA V3565 6 specimens; same collection data as for preceding; NMSA V3567 • 3 specimens; Grahamstown, Mountain Drive; NMSA V3569.

Fig. 18. (next page) Afrodonta, Amatholedonta gen. nov., Biomphalodonta gen. nov. and Costulodonta gen. nov. species, detail of protoconch morphology and teleoconch microsculpture. A-B. Af. unilamellaris (NMSA A9186). C-D. Am. bimunita gen. et comb. nov. (NMSA V9795). E-F. Am. fordycei gen. et sp. nov., paratype (NMSA V9343/T4266). G-H. B. forticostata gen. et sp. nov., paratype (NMSA V4886/ T4262). I-J. C. acinaces gen. et comb. nov. (NMSA A9183). K-L. C. bidens gen. et sp. nov., paratype (NMSA P1018/T4265). M-N. C. burnupi gen. et comb. nov. (NMSA A9187). O-P. C. pluridens gen. et sp. nov., paratype (NMSA V6287/T4269). Q-R. C. trilamellaris gen. et comb. nov. (NMSA W462). Scale bars for protoconchs $=100 \mu \mathrm{m}$; scale bars for microsculpture $=50 \mu \mathrm{m}$. 
HERBERT D.G., Dentate charopid snails of southern Africa
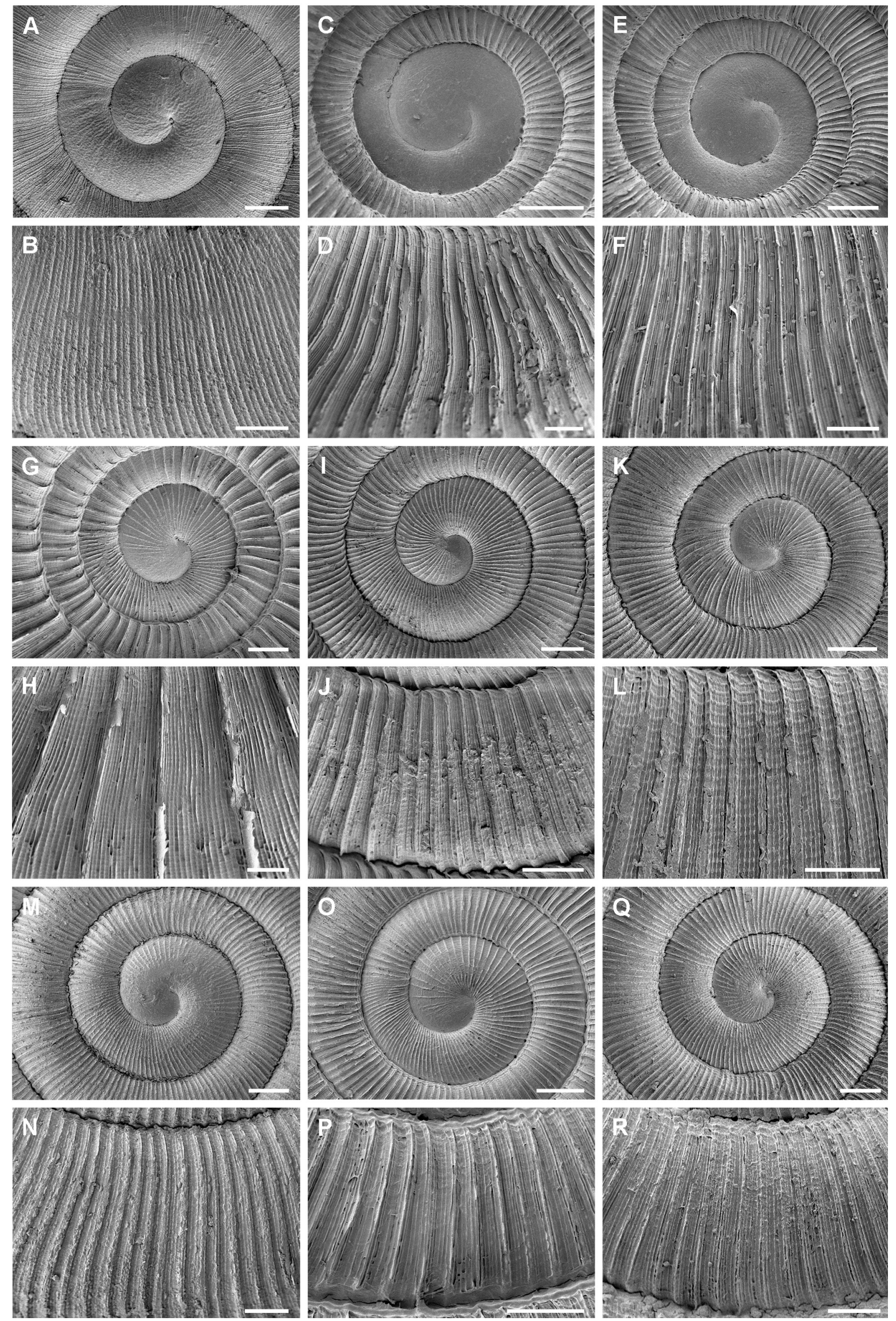


\section{Distribution and conservation}

A narrow-range endemic (Fig. 14), known only from the vicinity of Grahamstown, E. Cape, at $\pm 700 \mathrm{~m}$ a.s.l.; in leaf-litter of southern mistbelt forest. The only material available originates from the Albany Museum, Grahamstown and was collected by J. Farquhar in the early 1900s. Surveying forested habitats in the Grahamstown area should thus be identified as a priority in the hope of finding extant colonies of this species.
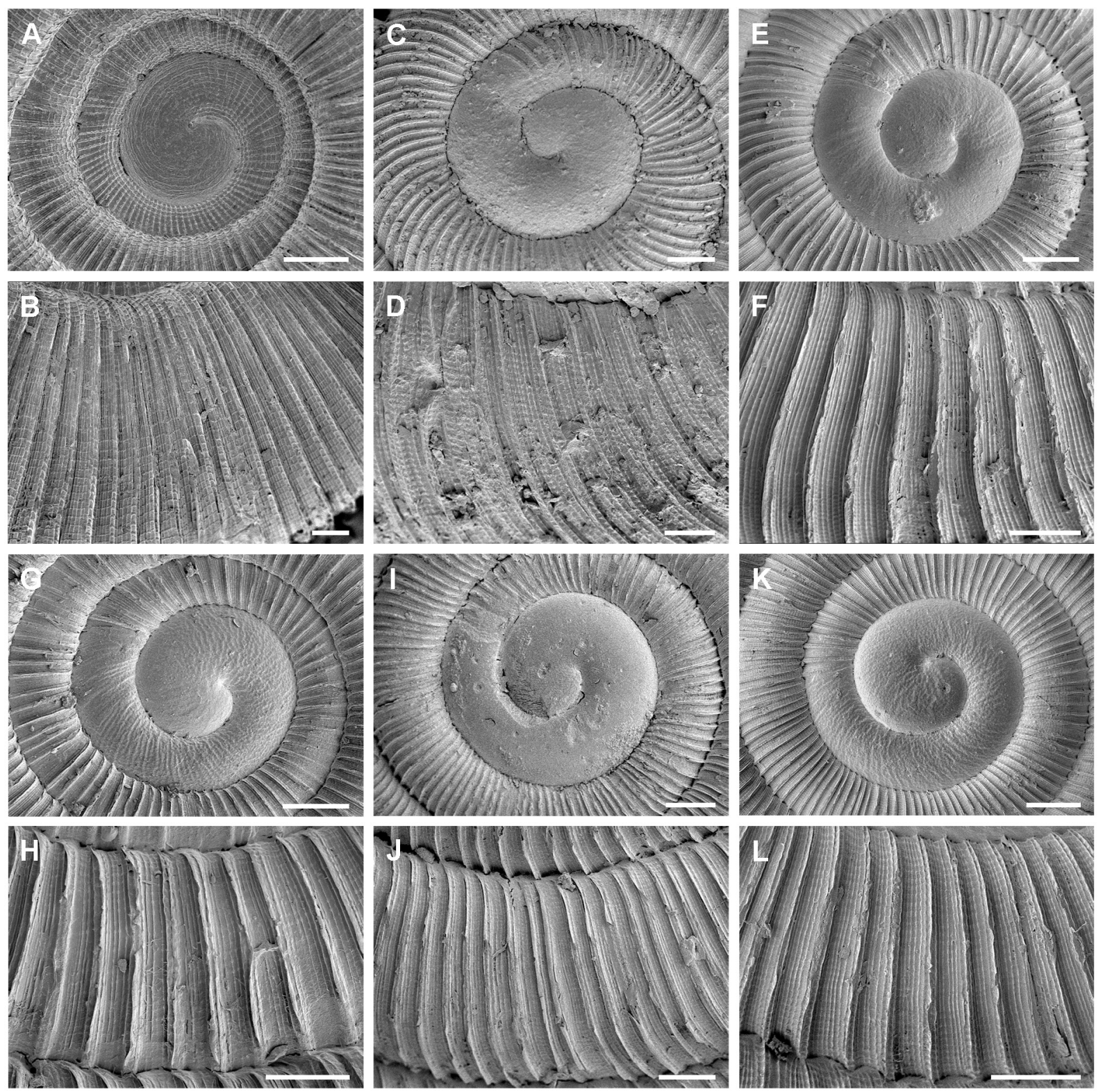

Fig. 19. Iterodonta gen. nov. and Phialodonta gen. nov. species, detail of protoconch morphology and teleoconch microsculpture. A-B. Iterodonta ammonita gen. et sp. nov., paratype (NMSA P1017/T4259). C-D. Phialodonta atromontana gen. et sp. nov., paratype (NMSA P1016/T4255). E-F. P. aviana gen. et sp. nov., paratype (NMSA W3524/T4247). G-H. P. introtuberculata gen. et comb. nov. (NMSA W216). I-J. P. perfida gen. et comb. nov., paratype (NMSA 2602/T617). K-L. P. rivalalea gen. et sp. nov., paratype (NMSA V4734/T4250). Scale bars for protoconchs $=100 \mu \mathrm{m}$; scale bars for microsculpture $=$ $50 \mu \mathrm{m}$. 


\section{Remarks}

Burnup (1912) proposed the name perfida on the grounds that the species was referable to Endodonta Albers, 1850 and that the name rotula Melvill \& Ponsonby, 1907 was thus a junior secondary homonym of Helix rotula Hombron \& Jacquinot, 1852 (non Lowe, 1831, nec Gould, 1851), a species that he also believed to be referable to Endodonta. Although rotula Melvill \& Ponsonby, 1907 is not in fact referable to Endodonta, following ICZN Art 59.3, the pre-1961 replacement name remains valid.

Resembles Phialodonta aviana gen. et sp. nov. in that the internal dentition is not visible through the aperture. In that species, however, there are two low, rounded, in-running parietal ridges and three inrunning ridge-like palatal denticles. P. aviana gen. et sp. nov. is also somewhat smaller (diameter up to $1.55 \mathrm{~mm}$ ). See remarks thereunder.

Phialodonta rivalalea gen. et sp. nov. urn:lsid:zoobank.org:act:4F0EED11-370A-4828-9A7A-9C320AA7BCFB Figs 14, 16I-L, 19K-L

\section{Diagnosis}

Shell small, spire slightly to distinctly raised; protoconch lacking axial sculpture; teleoconch sculpture of close-set, compound axial riblets, intervals with 4-5 finer intermediaries and extremely fine, close-set spiral threads; aperture with two narrow, in-running parietal lamellae and a narrow, in-running basocolumellar ridge; palatal region with three denticles recessed 1/5-1/4 whorl behind outer lip; an additional narrow, thread-like ridge immediately below suture evident by transparency; umbilicus very wide, its margin relatively sharply rounded. Shell pale corneous-brown to pale honey-brown when fresh; diameter up to $1.7 \mathrm{~mm}$.

\section{Etymology}

From the Latin rivus: a stream, and the Greek laleo $(\lambda \alpha \lambda \varepsilon o)$ : to talk, to utter; with reference to the Tsitsikamma region. Tsitsikamma (Outeniqua Khoi): 'the water that speaks'.

\section{Material examined}

\section{Holotype}

SOUTH AFRICA - W. Cape, Nature's Valley, Tsitsikamma Nat. Park, at camping ground entrance; 33.9723 ${ }^{\circ}$ S, $23.56306^{\circ}$ E; $10 \mathrm{~m}$ a.s.1.; 20 Sep. 2004; A. Moussalli and D. Stuart-Fox leg.; indigenous forest, in leaf-litter; diameter $1.68 \mathrm{~mm}$, height $0.79 \mathrm{~mm}$; NMSA W3114/T4251.

\section{Paratypes}

SOUTH AFRICA - W. Cape -7 specimens; Nature's Valley, Tsitsikamma Nat. Park, scenic drive on the way to park office; $33.9703^{\circ} \mathrm{S}, 23.53936^{\circ}$ E; $200 \mathrm{~m}$ a.s.1.; 16 Sep. 2004; A. Moussalli and D. StuartFox leg.; indigenous forest, in leaf-litter; NMSA W3125/T4253 1 specimen, same collection data as for holotype; NMSA P1012/T4252. - E. Cape - 5 specimens; Bloukrans River Valley, eastern side; $33.95377^{\circ}$ S, $23.65423^{\circ}$ E; $140 \mathrm{~m}$ a.s.l.; 21 Sep. 2003; D.G. Herbert leg.; in leaf-litter at base of road cutting through indigenous forest; NMSA W1171/T4249 • 14 specimens; Tsitsikamma Forest, near Paul Sauer Bridge over Storms River; 33.9682 ${ }^{\circ}$ S, $23.92634^{\circ}$ E; 260 m a.s.1.; 28 Apr. 1997; D.G. Herbert leg.; sorted from leaf-litter; NMSA V4734/T4250.

\section{Other material}

SOUTH AFRICA - 1 specimen; E. Cape, Tsitsikamma Forest, 'big tree' west of Storms River bridge; $33.9682^{\circ} \mathrm{S}, 23.8982^{\circ}$ E; $260 \mathrm{~m}$ a.s.1.; 1 Oct. 2002; J.P. Marais leg.; sorted from leaf-litter; NMSA W1768. 


\section{Description}

Shell small, diameter up to $1.7 \mathrm{~mm}, \mathrm{H} / \mathrm{D}$ ratio \pm 0.47 ; spire slightly to distinctly raised; whorls tightly coiled; last adult whorl descendant; suture narrowly indented, somewhat sunken; periphery evenly convex. Protoconch comprising apical cap plus approx. 1.0 whorl; diameter $\pm 410 \mu \mathrm{m}$; microscopically shagreened, lacking axial sculpture. Teleoconch of up to 3.5 whorls; sculptured by distinct, close-set, compound axial riblets, with 4-5 finer, intermediary axial threads; intervals between riblets 1-2 times width of riblets at whorl periphery; spiral sculpture of extremely fine, close-set threads more or less throughout. Umbilicus very wide, its margin relatively sharply rounded. Aperture broadly lunate; parietal region with two narrow, in-running lamellae, the upper one weaker and slightly more recessed; basocolumellar region with a similar recessed, narrow, in-running, lamella-like ridge (sometimes scarcely evident in apertural view); palatal region with three denticles recessed $1 / 5-1 / 4$ whorl behind outer lip, denticles evident by transparency, but hardly visible in apertural view, one just above mid-whorl, one just below mid-whorl, the third more basal, middle denticle situated slightly closer to aperture and often more elongate (particularly in juveniles); a fourth palatal structure in the form of a narrow, thread-like ridge lying immediately below the suture is evident by transparency in fresh juveniles and subadults. Shell pale corneous-brown to pale honey-brown when fresh.

\section{Distribution and conservation}

A narrow-range endemic (Fig. 14), known only from the coastal hinterland in the Tsitsikamma region, southern Cape, from the coast to $260 \mathrm{~m}$ a.s.l.; in leaf-litter of southern afrotemperate forest. The forests in this region fall within the Garden Route National Park and are thus afforded a high degree of protection.

\section{Remarks}

In terms of the overall facies of the shell, Phialodonta rivalalea gen. et sp. nov. is closest to P. aviana gen. et sp. nov. It differs from the latter in having parietal lamellae that are visible through the aperture, and in possessing a narrow, in-running baso-columellar ridge and a wider umbilicus.

\section{Discussion}

\section{Apertural barrier deposition}

Solem (1970) hypothesised that there are two contrasting modes of apertural tooth development in Afrodonta s. lat. In one group, including the type species, he suggested that tooth growth proceeds by continuous resorption and deposition at the posterior and anterior ends of the teeth, respectively, such that they develop at an early age and their appearance and position relative to the peristome remains more or less constant throughout growth. In a second group, he considered tooth deposition to be episodic. Here, after one set of denticles is laid down, tooth deposition ceases while the shell continues to grow for $1 / 4$ to $1 / 3$ of a whorl, after which another set of denticles is deposited and the process of resorbing the earlier set begins. The position of the denticles relative to the peristome is thus continually changing and the number of denticles present at any given time is dependent on the interplay between denticle resorption and deposition. In some instances, evidence of three sets of denticles may be apparent. To this latter group, Solem (1970) referred 'Afrodonta' bimunita, 'Af.' introtuberculata and 'Af.' kempi. Solem (1970) believed that these contrasting modes of apertural dentition deposition were incompatible with monophyly, and that at least two lineages were present within Afrodonta s. lat., but he stopped short of proposing a new genus for those exhibiting episodic tooth deposition, preferring instead to wait for confirmatory anatomical data.

The present study has found a good deal of evidence to support Solem's continuous vs. episodic interpretation of apertural tooth deposition. Three of the new genera described herein on the basis of protoconch morphology and teleoconch form and sculpture, namely Amatholedonta gen. nov., 
Biomphalodonta gen. nov. and Iterodonta gen. nov., consistently exhibit episodic tooth deposition. In contrast, Afrodonta, Costulodonta gen. nov. and Phialodonta gen. nov., for the most part, show continuous tooth deposition. However, it is noteworthy that in some species within these latter genera, tooth deposition may be considered both continuous and episodic. For example, in Afrodonta geminodonta sp. nov. and Phialodonta atromontana gen. et sp. nov. the parietal teeth are deposited continually, but the palatal teeth are not spirally continuous and must be deposited in a more discontinuous or episodic manner. Similarly, in Phialodonta introtuberculata gen. et comb. nov., which lacks parietal dentition, deposition of the palatal teeth is spirally discontinuous and therefore episodic.

There is thus not a clear-cut dichotomy with species having either continuous or episodic tooth deposition and neither is this interpretation of tooth deposition consistent within the genera as shown above. An alternative way to interpret apertural dentition might be to consider it either a primarily spiral feature or a primarily axial one. Where the dentition takes the form of in-running ridges or lamellae, these are primarily spiral and in the few exceptions mentioned above that have discontinuous palatal dentition, the teeth are essentially interrupted structures of spiral origin. In Amatholedonta gen. nov., Biomphalodonta gen. nov. and Iterodonta gen. nov., which never exhibit any kind of in-running ridges or lamellae, the apertural teeth might more appropriately be considered primarily axial features which are either continuous axial ridges (Iterodonta gen. nov.) or interrupted (Amatholedonta gen. nov. and Biomphalodonta gen. nov.), taking the form of axially aligned rows of teeth. Viewing the development of apertural dentition in this manner is then fully consistent with the interpretation of genera as detailed above.

\section{Phylogenetic considerations}

The more detailed study of the aperturally dentate southern African charopids undertaken during the course of this revision has confirmed Solem's belief that Afrodonta s. lat. is not a single morphologically coherent entity. Rather, it is an assemblage of genus-level taxa that until now have been grouped together on account of a single shared, but not necessarily homologous character, namely the possession of apertural barriers. Closer scrutiny of protoconch and teleoconch microsculpture using scanning electron microscopy has revealed patterns of variation consistent with the subdivision of Afrodonta s. lat. into separate morphologically congruent groups that I have proposed as new genera. These in turn exhibit patterns of apertural tooth deposition congruent with the continuous vs. episodic (spiral vs. axial) interpretation discussed above. Considerable variation in protoconch and teleoconch microsculpture has also been observed in charopids from Australia (Stanisic 1990; Hyman \& Stanisic 2005; Stanisic et al. 2010), New Zealand (Marshall \& Barker 2008) and the Pacific Islands (Solem 1983) and, as in Afrodonta s. lat., congruent patterns in this variation have provided useful taxonomic characters for the delimitation and diagnosis of genera.

The considerable diversity in shell morphology and sculpture exhibited by the aperturally dentate charopids of southern Africa, together with the differing modes of apertural barrier development, strongly indicates, as suggested by Solem (1970), that they represent a polyphyletic assemblage, rather than a monophyletic entity. The single shared character - the possession of apertural barriers is almost certainly a convergent character with several independent origins. Climo (1978) and Solem (1980: 15) both considered apertural barriers to have evolved multiple times in New Zealand and Pacific Island charopids, respectively. At present there is insufficient evidence to illuminate the issue of the phylogenetic affinities of the genera discussed herein, but it is likely that some will prove to be more closely related to edentate species currently referred to Trachycystis $\mathrm{s}$. lat. than to other dentate charopids. Examples indicative of such relationships include the similarity between Costulodonta bidens gen. et sp. nov. and 'Trachycystis' contabulata, and that between Biomphalodonta forticostata gen. et sp. nov. and ' $T$.' bathycoele and ' $T$.' bifoveata. A more in-depth investigation of these phylogenetic issues will require anatomical and molecular data. 


\section{Conservation}

With the exception of Afrodonta novemlamellaris all species discussed herein are endemic to South Africa, though the morphologically similar $A f$. farquhari is very likely to range northward into coastal Mozambique. Three further species of Afrodonta range widely in eastern South Africa, but based on the available distribution data, the remaining Afrodonta species, plus all species of Amatholedonta gen. nov., Biomphalodonta gen. nov., Costulodonta gen. nov., Iterodonta gen. nov. and Phialodonta gen. nov., are narrow-range endemics. Within this rather imprecise categorisation, eight are local endemics with $<100 \mathrm{~km}$ between the most widely separated localities and eleven are site endemics known only from a single locality or with $<10 \mathrm{~km}$ between the most widely separated localities (Table 1).

The widely distributed species are all catholic in their habitat requirements and are found in a wide variety of forest types, some extending into woodland and thicket. In contrast, the narrow-range species are all confined to a single forest type. In KwaZulu-Natal and the interior of E. Cape this is either southern mistbelt forest or, at higher altitudes, northern afrotemperate forest. In the southern Cape, narrow-range species are found primarily in southern afrotemperate forests, the sole exception being Phialodonta atromontana gen. et sp. nov., which has only been found in low succulent thicket.

As with all narrowly endemic species, the conservation of these local and site endemics is a matter of concern. In the species treatments above I have indicated whether the species are known to occur in formally protected areas or whether there are formally protected areas in the neighbourhood of occurrence that could be surveyed with the aim of locating additional colonies in conserved areas. Whereas many of the local and site endemics are recently discovered species described herein, five of the site endemics date from material collected in the early 1900s and in every case the original samples remain the only ones known. This likely indicates that they are genuinely of very limited distribution and highlights the need for targeted field work aimed at locating extant colonies. Ultimately, the conservation of these largely forest-dependent snails depends upon conserving their habitat. I have earlier highlighted the importance of indigenous forests from the perspective of terrestrial mollusc conservation in South Africa and outlined the threats facing these habitats (Herbert 1998). Preserving the integrity of isolated habitat fragments, however, may not be sufficient and may not be possible under conditions of rapid climate change.

\section{Acknowledgements}

I thank Mary Cole (ELM) and Linda Davis (NMSA) for assistance in the field as well as the numerous colleagues mentioned in the material examined sections for collecting leaf-litter samples on my behalf. Linda Davis also assisted in curating the type material of the new species and I thank Jon Ablett for information regarding the status and registration numbers of types in the NHMUK. For access to SEM facilities I acknowledge the Centre for Electron Microscopy, University of KwaZuluNatal, Pietermaritzburg. Collecting permits were provided by: the Department of Economic Affairs, Environment and Tourism, E. Cape (per Mary Cole); Ezemvelo KwaZulu-Natal Wildlife (4674) and Mpumalanga Tourism and Parks (MPV.5109/5174). Mary Cole also provided useful comments on the manuscript. This research was supported by Incentive Funding from the South African National Research Foundation (Grant No 81078).

\section{References}

Bouchet P., Rocroi J.P., Hausdorf B., Kaim A., Kano Y., Nützel A., Parkhaev P., Schrödl M. \& Strong E.E. 2017. Revised classification, nomenclator and typification of gastropod and monoplacophoran families. Malacologia 61 (1-2): 1-526. https://doi.org/10.4002/040.061.0201 
Table 1. Endemicity levels of species, based on their currently known distribution. Local endemics, $<100 \mathrm{~km}$ between the most widely separated localities; site endemics. known from a single locality or with $<10 \mathrm{~km}$ between the most widely separated localities.

\begin{tabular}{|c|c|c|}
\hline Widespread & Local endemics & Site endemics \\
\hline Afrodonta bilamellaris & $\begin{array}{l}\text { Afrodonta geminodonta } \\
\text { sp. nov. }\end{array}$ & Afrodonta mystica sp. nov. \\
\hline Afrodonta connollyi & $\begin{array}{l}\text { Amatholedonta bimunita } \\
\text { gen. et comb. nov. }\end{array}$ & Afrodonta pentodon sp. nov. \\
\hline Afrodonta farquhari & $\begin{array}{l}\text { Biomphalodonta forticostata } \\
\text { gen. et sp. nov. }\end{array}$ & Afrodonta unilamellaris \\
\hline $\begin{array}{l}\text { Afrodonta inhluzaniensis } \\
\text { (both subspp.) }\end{array}$ & $\begin{array}{l}\text { Costulodonta pluridens } \\
\text { gen. et sp. nov. }\end{array}$ & $\begin{array}{l}\text { Amatholedonta fordycei } \\
\text { gen. et sp. nov. }\end{array}$ \\
\hline \multirow[t]{7}{*}{ Afrodonta novemlamellaris } & $\begin{array}{l}\text { Iterodonta ammonita } \\
\text { gen. et sp. nov. }\end{array}$ & $\begin{array}{l}\text { Costulodonta acinaces } \\
\text { gen. et comb. nov. }\end{array}$ \\
\hline & $\begin{array}{l}\text { Phialodonta aviana } \\
\text { gen. et sp. nov. }\end{array}$ & $\begin{array}{l}\text { Costulodonta bidens } \\
\text { gen. et sp. nov. }\end{array}$ \\
\hline & $\begin{array}{c}\text { Phialodonta introtuberculata } \\
\text { gen. et comb. nov. }\end{array}$ & $\begin{array}{l}\text { Costulodonta burnupi } \\
\text { gen. et comb. nov. }\end{array}$ \\
\hline & $\begin{array}{l}\text { Phialodonta rivalalea } \\
\text { gen. et } \mathrm{sp} \text {. nov. }\end{array}$ & $\begin{array}{l}\text { Costulodonta trilamellaris } \\
\text { gen. et comb. nov. }\end{array}$ \\
\hline & & $\begin{array}{l}\text { Phialodonta agulhasae } \\
\text { gen. et sp. nov. }\end{array}$ \\
\hline & & $\begin{array}{l}\text { Phialodonta atromontana } \\
\text { gen. et sp. nov. }\end{array}$ \\
\hline & & $\begin{array}{l}\text { Phialodonta perfida } \\
\text { gen. et comb. nov. }\end{array}$ \\
\hline
\end{tabular}

Bruggen A.C. van. 1980. Gondwanaland connections in the terrestrial molluses of Africa and Australia. Journal of the Malacological Society of Australia 4 (4): 215-222.

https://doi.org/10.1080/00852988.1980.10673930

Bruggen A.C. van. 1988. A record of the genus Cerastua (Mollusca, Gastropoda Pulmonata: Enidae) from Zambia, with a preliminary list of the terrestrial molluscs of that country. Proceedings of the Koninklijke Nederlandse Akademie van Wetenschappen 91 (1): 1-17.

Bruggen A.C. van. 2007. Terrestrial molluscs recorded from Mt. Mulanje, Malawii. Nyala 24: 17-37.

Bruggen A.C. van \& Meredith H.M. 1984. A preliminary analysis of the land molluscs of Malawii. In: Solem A. \& Bruggen A.C. van (eds) World-wide Snails - Biogeographical Studies on Non-marine Mollusca: 156-171. E.J. Brill/W. Backhuys, Leiden.

Burnup H.C. 1912. On Afrodonta Melv. and Pons., with descriptions of new species. Annals of the Natal Museum 2 (3): 333-343.

Climo F.M. 1978. Classification of the New Zealand Arionacea (Mollusca: Pulmonata). A review of the New Zealand charopine snails with lamellate apertures. Records of the National Museum of New Zealand 1 (12): 177-201. 
Connolly M. 1912. A revised reference list of South African non-marine Mollusca; with descriptions of new species in the South African Museum. Annals of the South African Museum 11: 59-306. https://doi.org/10.5962/bhl.part.5071

Connolly M. 1925. The non-marine Mollusca of Portuguese East Africa. Transactions of the Royal Society of South Africa 12 (3): 105-220. https://doi.org/10.1080/00359192409519300

Connolly M. 1933. On South African Endodontidae. Part 2. Annals of the Natal Museum 7 (2): 145-150.

Connolly M. 1939. A monographic survey of South African non-marine Mollusca. Annals of the South African Museum 33: 1-660.

Herbert D.G. 1998. Molluscan conservation in South Africa: diversity, issues and priorities. In: Killeen I.J., Seddon M.B. \& Holmes A.M. (eds) Molluscan Conservation: a Strategy for the $21^{\text {st }}$ Century. Journal of Conchology, Special Volume 2: 61-76.

Herbert D. \& Kilburn D. 2004. Field Guide to the Land Snails and Slugs of Eastern South Africa. Natal Museum, Pietermaritzburg.

Hyman I.T. \& Stanisic J. 2005. New charopid land snails chiefly from limestone outcrops in eastern New South Wales (Eupulmonata: Charopidae). Memoirs of the Queensland Museum 50 (2): 219-302.

Marshall B.A. \& Barker G.M. 2008. A revision of the New Zealand landsnails referred to Allodiscus Pilsbry, 1892 and Pseudallodiscus Climo, 1971, with the introduction of three new genera (Mollusca: Gastropoda: Charopidae). Tuhinga 19: 57-167.

Martini J.E.J. 1987. Limestone and Dolomite Resources of the Republics of South Africa, Bophuthatswana, Ciskei, Transkei and Venda. Handbook of the Geological Survey, No 9. Department of Mineral and Energy Affairs, Pretoria.

Melvill J.C. \& Ponsonby J.H. 1907. Descriptions of fifteen terrestrial Mollusca from South Africa. Annals andMagazine of Natural History, Series 7, 19(109):94-101.https://doi.org/10.1080/00222930709487233

Melvill J.C. \& Ponsonby J.H. 1908. Descriptions of nine terrestrial Mollusca from South Africa. Annals and Magazine of Natural History, Series 8, 1 (2): 129-136. https://doi.org/10.1080/00222930808692373

MolluscaBase 2018. Afrodonta Melvill \& Ponsonby, 1908. Available from:

http://molluscabase.org/aphia.php?p=taxdetails\&id=995317 [accessed on 8 Apr. 2019].

Mucina L. \& Rutherford M.C. (eds) 2006. The Vegetation of South Africa, Lesotho and Swaziland. Strelitzia 19. South African National Biodiversity Institute, Pretoria.

Muratov I.V., Abdou A. \& Bouchet P. 2005. Charopid land snails (Gastropoda Pulmonata Charopidae) from Mayotte, Comores: alive and well. Tropical Zoology 18: 171-208.

Schileyko A.A. 2001. Treatise on Recent terrestrial pulmonate molluscs. Part 7. Endodontidae, Thyrophorellidae, Charopidae. Ruthenica, Suppl. 2: 881-1034.

Solem A. 1970. The land snail genus Afrodonta (Mollusca: Gastropoda: Endodontidae). Annals of the Natal Museum 20: 342-364.

Solem A. 1976. Endodontoid Land Snails from Pacific Islands (Mollusca: Pulmonata: Sigmurethra). Part I. Family Endodontidae. Field Museum, Chicago. https://doi.org/10.5962/bhl.title.2554

Solem A. 1983. Endodontoid Land Snails from Pacific Islands (Mollusca: Pulmonata: Sigmurethra). Part II. Families Punctidae and Charopidae, zoogeography. Field Museum, Chicago. https://doi.org/10.5962/bhl.title.2553

Stanisic J. 1990. Systematics and biogeography of eastern Australian Charopidae (Mollusca, Pulmonata) from subtropical rainforests. Memoirs of the Queensland Museum 30 (1): 1-241. 
Stanisic J., Shea M., Potter D. \& Griffiths O. 2010. Australian Land Snails Vol. 1. A Field Guide to the Eastern Australian Species. Bioculture Press, Mauritius.

Manuscript received: 13 August 2019

Manuscript accepted: 6 January 2020

Published on: 17 April 2020

Topic editor: Rudy Jocqué

Section editor: Thierry Backeljau

Desk editor: Jeroen Venderickx

Printed versions of all papers are also deposited in the libraries of the institutes that are members of the EJT consortium: Muséum national d'Histoire naturelle, Paris, France; Meise Botanic Garden, Belgium; Royal Museum for Central Africa, Tervuren, Belgium; Royal Belgian Institute of Natural Sciences, Brussels, Belgium; Natural History Museum of Denmark, Copenhagen, Denmark; Naturalis Biodiversity Center, Leiden, the Netherlands; Museo Nacional de Ciencias Naturales-CSIC, Madrid, Spain; Real Jardín Botánico de Madrid CSIC, Spain; Zoological Research Museum Alexander Koenig, Bonn, Germany; National Museum, Prague, Czech Republic. 